\title{
Quantification of Mass Loading to Strawberry Creek near the Gilt Edge Mine, Lawrence County, South Dakota, June 2003
}

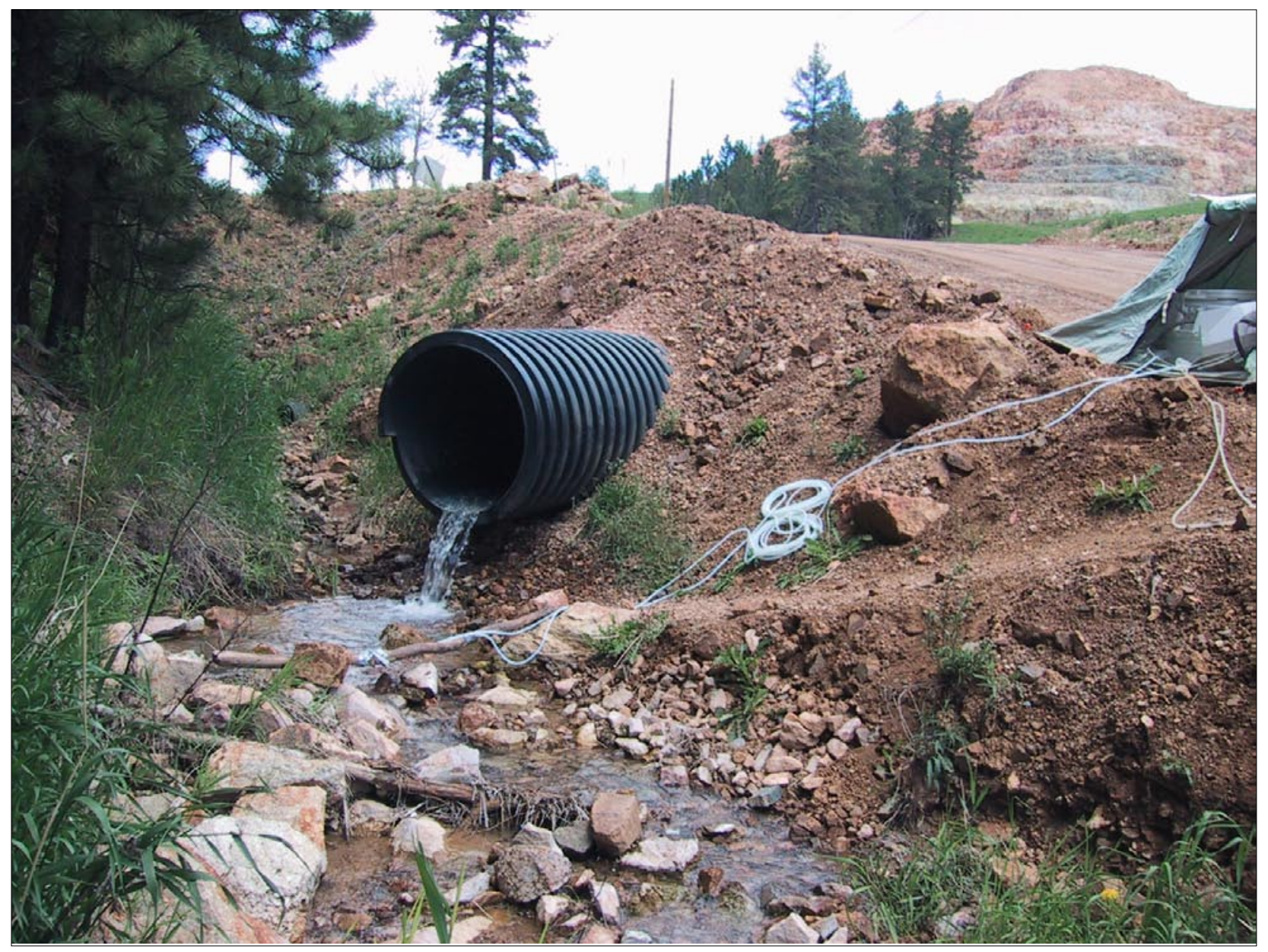

Prepared in cooperation with the

U.S. Environmental Protection Agency

\section{Scientific Investigations Report 2006-5006}

U.S. Department of the Interior

U.S. Geological Survey 
Cover photo: Pipe discharging the flow of Strawberry Creek from the Gilt Edge mine, South Dakota. The injection of lithium bromide tracer was from the tubing visible just downstream from the pipe. 


\section{Quantification of Mass Loading to Strawberry Creek near the Gilt Edge Mine, Lawrence County, South Dakota, June 2003}

By Briant A. Kimball, Robert L. Runkel, Katherine Walton-Day, and Joyce E. Williamson

Scientific Investigations Report 2006-5006

Prepared in cooperation with the

U.S. Environmental Protection Agency

U.S. Department of the Interior

U.S. Geological Survey 


\section{U.S. Department of the Interior \\ P. Lynn Scarlett, Acting Secretary}

\section{U.S. Geological Survey \\ P. Patrick Leahy, Acting Director}

Salt Lake City, 2006

For additional information write to:

U.S. Geological Survey

Director, USGS Utah Water Science Center

2329 W. Orton Circle

Salt Lake City, UT 84119-2047

Email: GS-W-UTpublic-info@usgs.gov

URL: http://ut.water.usgs.gov/

For more information about the USGS and its products:

Telephone: 1-888-ASK-USGS

World Wide Web: http://www.usgs.gov/

Any use of trade, firm, or product names is for descriptive purposes only and does not imply endorsement by the U.S. Government

Although this report is in the public domain, permission must be secured from the individual copyright owners to reproduce any copyrighted materials contained within this report.

Suggested citation:

Kimball, B.A., Runkel, R.L., Walton-Day, K., and Williamson, J.E., 2006, Quantification of mass loading to

Strawberry Creek near the Gilt Edge mine, Lawrence County, South Dakota, June 2003: U.S. Geological Survey

Scientific Investigations Report 2006-5006, 41 p. 


\section{Contents}

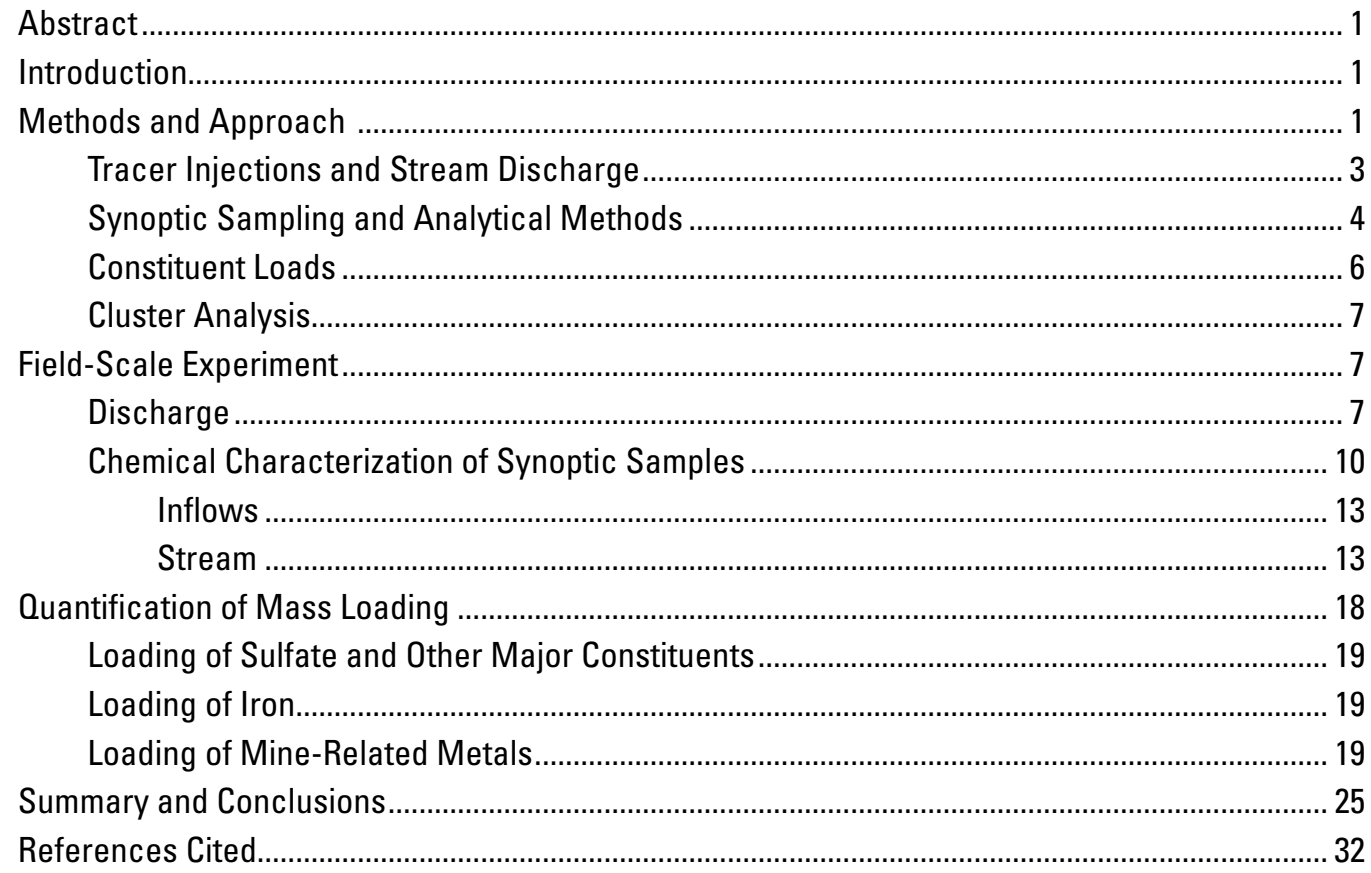

\section{Figures}

Figure 1. Location of sampling sites and the general geologic setting with pit lakes and shear zones, Strawberry Creek, South Dakota.

Figure 2. Variation of bromide concentration and calculated discharge with distance along the study reach, Strawberry Creek, South Dakota.

Figure 3. Variation of (A) bromide and (B) sulfate concentrations with time during the injection period, Strawberry Creek, South Dakota.

Figure 4. Variation of $(\mathrm{A}) \mathrm{pH}$ and $(\mathrm{B})$ sulfate concentration with distance along the study reach, Strawberry Creek, South Dakota.

Figure 5. Variation of (A) sum of base metal concentrations with $\mathrm{pH}$ and (B) manganese concentration with sulfate concentration for inflow samples and for the Sunday pit lake, Strawberry Creek, South Dakota..

Figure 6. Variation of dissolved and colloidal (A) iron, (B) copper, and (C) zinc concentrations with distance along the study reach, Strawberry Creek, South Dakota.

Figure 7. Normalized cumulative instream load for total (A) calcium, magnesium, sodium, potassium, alkalinity, sulfate, silica, arsenic, strontium; (B) aluminum, cadmium, copper, manganese, nickel, zinc; and (C) iron

Figure 8. Variation of (A) sulfate load with distance along the study reach and (B) change in total sulfate load for individual segments along Strawberry Creek, South Dakota.

Figure 9. (A) Gilt Edge mine discharge, (B) seeps typical of those from 358 to 858 meters, and (C) iron-rich seeps from 1,708 to 1,982 meters.

Figure 10. Variation of (A) total silica load with distance along the study reach and (B) change in total silica load for individual catchments along Strawberry Creek, South Dakota. 
Figure 11. Variation of $(A)$ iron load with distance along the study reach and $(B)$ change in iron load for individual catchments along Strawberry Creek, South Dakota.

Figure 12. Variation of $(A)$ copper load with distance along the study reach and $(B)$ change in copper load for individual catchments along Strawberry Creek, South Dakota.

Figure 13. Variation of (A) zinc load with distance along the study reach and (B) change in zinc load for individual catchments along Strawberry Creek, South Dakota.

\section{Tables}

Table 1. Accuracy, method detection limit, and analytical and sampling precision for synoptic samples.

Table 2. Sample identification, source, downstream distance, description, site number, $\mathrm{pH}$, specific conductance, and cluster analysis group for synoptic samples, Strawberry and Bear Butte Creeks, South Dakota...

Table 3. Bromide tracer, pump rate, injectate concentration, and calculated discharge for synoptic stream samples, Strawberry Creek, South Dakota

Table 4. Concentration of major ions in synoptic samples collected from Strawberry Creek, South Dakota, June 27, 2003.

Table 5. Concentration of trace elements in synoptic samples collected from Strawberry and Bear Butte Creeks, South Dakota, June 27, 2003.

Table 6. Median values of dissolved concentrations for selected constituents for inflow groups defined by cluster analysis.

Table 7. Median values of dissolved and colloidal concentrations for selected constituents for stream groups defined by cluster analysis.

Table 8. Mass loading for individual stream segments and summary of loading for Strawberry Creek, South Dakota 


\section{Conversion Factors, Datums, and Abbreviated Water-Quality Units}

\begin{tabular}{lcl}
\hline \multicolumn{1}{c}{ Multiply } & \multicolumn{1}{c}{ By } & \multicolumn{1}{c}{ To obtain } \\
\hline kilogram per day $(\mathrm{kg} /$ day) & 2.2 & pound per day $(\mathrm{lb} / \mathrm{day})$ \\
liter per second $(\mathrm{L} / \mathrm{s})$ & 28.3 & cubic foot per second $\left(\mathrm{ft}{ }^{3} / \mathrm{s}\right)$ \\
meter $(\mathrm{m})$ & 3.281 & foot $(\mathrm{ft})$ \\
micrometer $(\mu \mathrm{m})$ & 0.00003937 & inch $(\mathrm{in})$. \\
milligram per second & 0.0000022 & pound per second $(\mathrm{lb} / \mathrm{s})$ \\
milliliter $(\mathrm{mL})$ & 0.03382 & ounce, fluid $(\mathrm{fl} . \mathrm{oz})$ \\
\hline
\end{tabular}

Temperature in degrees Celsius $\left({ }^{\circ} \mathrm{C}\right)$ may be converted to degrees Fahrenheit $\left({ }^{\circ} \mathrm{F}\right)$ as follows:

${ }^{\circ} \mathrm{F}=\left(1.8 x^{\circ} \mathrm{C}\right)+32$.

Horizontal coordinate information is referenced to North American Datum of 1983 (NAD 83). Vertical coordinate information and altitude are referenced to the North American Vertical Datum of 1988 (NAVD 88).

Specific conductance is reported in microsiemens per centimeter at 25 degrees Celsius $\left(\mu \mathrm{S} / \mathrm{cm}\right.$ at $\left.25^{\circ} \mathrm{C}\right)$.

Concentrations of chemical constituents in water are reported either in milligrams per liter (mg/L), micrograms per liter $(\mu \mathrm{g} / \mathrm{L})$, or millimoles per liter $(\mathrm{mM} / \mathrm{L})$. 



\title{
Quantification of Mass Loading to Strawberry Creek near the Gilt Edge Mine, Lawrence County, South Dakota, June 2003
}

\author{
By Briant A. Kimball, Robert L. Runkel, Katherine Walton-Day, and Joyce E. Williamson
}

\section{Abstract}

Although remedial actions have taken place at the Gilt Edge mine in the Black Hills of South Dakota, questions remain about a possible hydrologic connection along shear zones between some of the pit lakes at the mine site and Strawberry Creek. Spatially detailed chemical sampling of stream and inflow sites occurred during low-flow conditions in June 2003 as part of a mass-loading study by the U.S. Geological Survey to investigate the possible connection of shear zones to the stream. Stream discharge was calculated by tracer dilution; discharge increased by 25.3 liters per second along the study reach, with 9.73 liters per second coming from three tributaries and the remaining increase coming from small springs and dispersed, subsurface inflow. Chemical differences among inflow samples were distinguished by cluster analysis and indicated that inflows ranged from those unaffected by interaction with mine wastes to those that could have been affected by drainage from pit lakes. Mass loading to the stream from several inflows resulted in distinct chemical changes in stream water along the study reach. Mass loading of the minerelated metals, including cadmium, copper, nickel, and zinc, principally occurred from the discharge from the Gilt Edge mine, and those metals were substantially attenuated downstream. Secondary loadings of metals occurred in the vicinity of the Oro Fino shaft and from two more inflows about $200 \mathrm{~m}$ downstream from there. These are both locations where shear zones intersect the stream and may indicate loading associated with these zones. Loading downstream from the Oro Fino shaft had a unique chemical character, high in base-metal concentrations, that could indicate an association with water in the pit lakes. The loading from these downstream sources, however, is small in comparison to that from the initial mine discharge and does not appear to have a substantial impact on Strawberry Creek.

\section{Introduction}

The Gilt Edge mine, near Deadwood in Lawrence County, South Dakota, is part of the famous mining district in the northern Black Hills. Mining for gold, copper, and tungsten started in the Gilt Edge deposits in 1876. In the early mining days, small mines began dumping metal-rich mill tailings into nearby Strawberry Creek and Bear Butte Creek (U.S. Environmental Protection Agency, 2005). A larger open-pit mine began operation in 1986. Three open pits were constructed along with a cyanide heap-leach pad and a large waste-rock dump. Although some clean up of historical tailings was done, the operator of the mine went out of business and was unable to continue site controls. The open pit lakes filled, and eventually, in 2000, the site was proposed for the Superfund National Priorities List and the U.S. Environmental Protection Agency (EPA) has developed plans for clean up and control of contaminants (U.S. Environmental Protection Agency, 2005).

As work on the site has progressed it has become necessary to understand if there is a connection, through shear zones associated with the ore bodies, between metal-rich water in the pits and in Strawberry Creek (H. Dawson, U.S. Environmental Protection Agency, written commun., 2002). To answer this question, the U.S. Geological Survey (USGS) designed a mass-loading study to identify the locations of metal loading to Strawberry Creek and to quantify the extent of that loading. The purpose of this report is to present results of that massloading study and to evaluate the possibility of a connection between the mine pits and Strawberry Creek. Strawberry Creek discharges from the area of the Gilt Edge mine to its confluence with Bear Butte Creek (fig. 1). Several remedial actions have taken place at the Gilt Edge mine and in tributaries of Strawberry Creek, but the treatment operations were not in operation at the time of the mass-loading study.

This study was done cooperatively by the EPA and the USGS Toxic Substances Hydrology Program. Valuable field assistance was provided by Helen Dawson from the EPA, George Ritz of the USGS and EPA, and Francesco Bianchi, of Florence, Italy.

\section{Methods and Approach}

The mass-loading approach used here addresses the problem of solute source determination (Kimball and others, 2002). The approach is based on two well-established techniques: the tracer-dilution method (Kilpatrick and Cobb, 1985) and synoptic sampling (Bencala and McKnight, 1987). The tracer-dilution method provides estimates of stream discharge that are in turn used to quantify the amount of water entering 

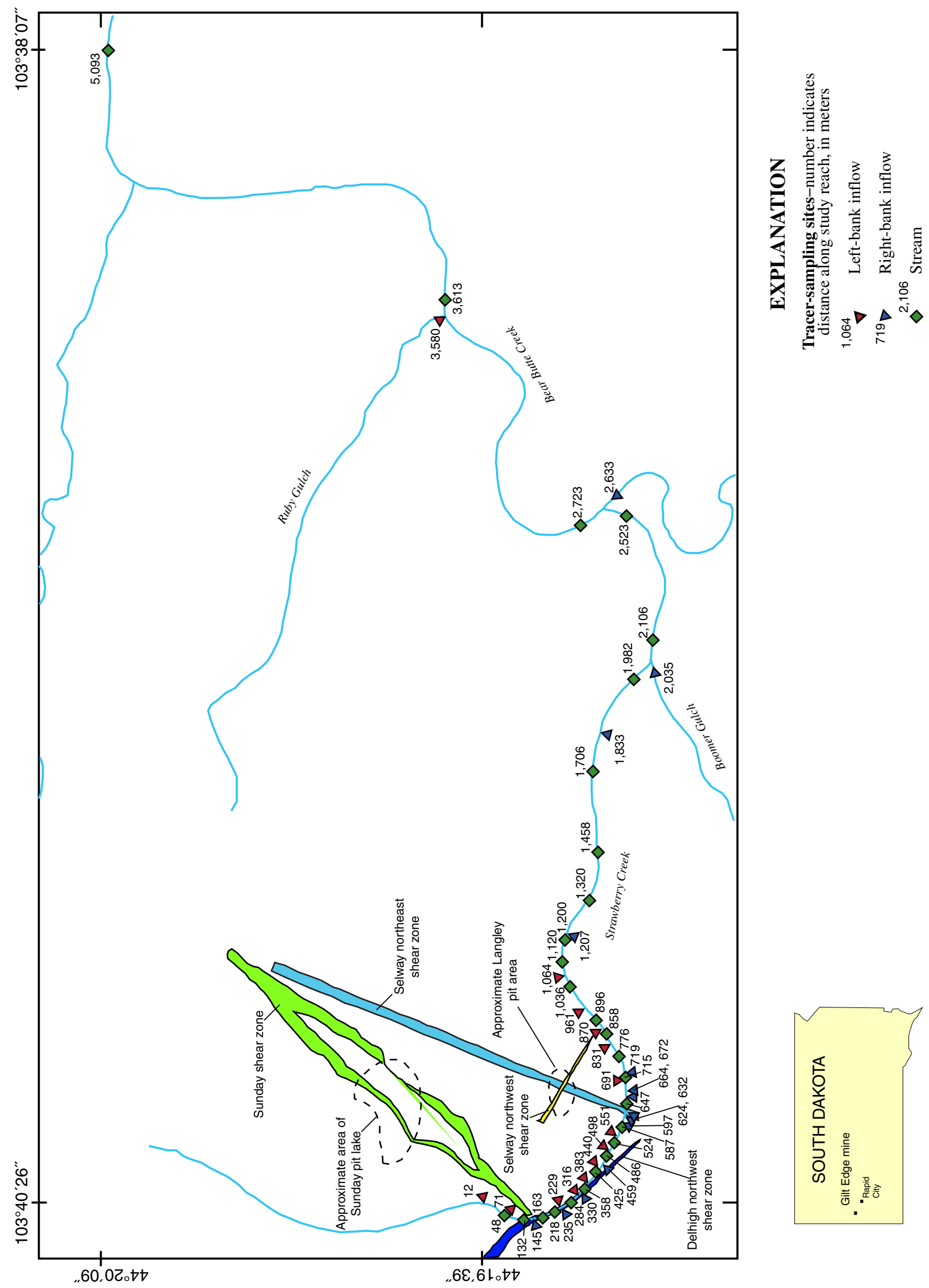

त्] 
the stream in a given stream segment through tributary and ground-water inflow. Synoptic sampling of stream and inflow chemistry provides a spatially detailed 'snapshot' of water quality in the stream and the inflows that influence changes in the stream. When used together, these techniques provide a description of a watershed that includes both discharge and concentration that may then be used to determine mass loading of chemical constituents associated with different sources of surface and ground water. Resulting longitudinal loading profiles will quantify any possible connection between the mine and Strawberry Creek.

This study was undertaken during low-flow conditions in June 2003. Application of the method to low-flow conditions provides a focus on metals that enter the stream on a continuous basis, but the values of loading from the low-flow study may not be representative of a mean annual value needed for remediation engineering. A critical step in this approach was to walk the entire study reach and identify visible inflows and areas of likely ground-water inflow. Stream sampling sites were located upstream and downstream from these inflows and in locations that appeared to bracket areas of potential ground-water inflow. These areas were identified during stream reconnaissance by considering changes in vegetation, geomorphologic controls, and geologic structure. Distance along the study reach was measured from the tracer-injection site, which was assigned a distance of $0 \mathrm{~m}$. This downstream metric provides an ordinate for the study and for any future computer simulation studies that might be conducted to better understand loading and geochemical reactions (Runkel and Kimball, 2002). Each stream site represents the downstream end of a stream segment, and the stream segments divide the watershed into increments to account for instream and inflow loads. At this level of spatial detail, changes in stream chemistry and discharge between stream sampling sites reflect a net metal load for each segment. Specific sources that are responsible for the loading within specific stream segments, however, cannot always be identified at this stream reach scale.

\section{Tracer Injections and Stream Discharge}

Quantifying discharge in mountain streams by the traditional velocity-area method (Rantz, 1982) can be compromised becasue of the roughness of the streambed and the variability caused by pools and riffles (Jarrett, 1992). Furthermore, a substantial percentage of stream water may be discharging through porous areas of the streambed that make up the hyporheic zone (Zellweger and others, 1989). Discharge measured with the velocity-area method does not account for discharge through the hyporheic zone, and therefore discharge estimates based on the velocity-area method may result in an underestimate of metal loads (Zellweger and others, 1989). Another limitation of the velocity-area method for the characterization of metal loads is the time limit it may place on the number of sites that can be measured in one day. In some studies, numerous (often, about 60) instream samples were collected dur- ing a single day to characterize stream and inflow chemistry. Velocity-area discharge measurements made in conjunction with sample collection at such a large number of sites can be problematic, if not impossible.

An alternative means of estimating discharge used here is the tracer-dilution method (Kilpatrick and Cobb, 1985). To apply the tracer-dilution method, an inert tracer is continuously injected into the stream at a constant rate and concentration. A key factor is the ability to maintain a constant rate during the continuous tracer injection. For this study, the tracer injection was controlled with precision metering pumps linked to a data logger. The data logger regulates the time that the pump runs during each 6-second period. As battery voltage decreases, the data logger increases the time that the pump runs during the 6 -second period to maintain a constant injection rate. Given sufficient time with a constant injection rate, all parts of the stream, including side pools and hyporheic zones, will become saturated with tracer, and instream concentrations will reach a plateau (Broshears and others, 1993). Decreases in plateau concentration reflect downstream dilution of the tracer by additional surface and ground water entering the channel. Consideration of this dilution allows for the calculation of discharge at each stream site. Application of the tracer-dilution method addresses both of the problems noted above: (1) the tracer enters porous areas of the streambed, accounting for discharge through the hyporheic zone; and (2) collection of tracer samples after plateau concentrations are achieved provides the ability to obtain discharge estimates at numerous locations.

Mass-balance equations were used to determine stream discharge based on the observed dilution of the bromide tracer. At near-neutral $\mathrm{pH}$ values measured in Strawberry Creek, lithium bromide was used because bromide has little tendency to sorb in neutral $\mathrm{pH}$ waters. Injected bromide provided a large concentration contrast with background bromide. In addition, spatial variability in background concentrations was low, such that background concentrations were nominally uniform. Given these conditions, stream discharge at any location downstream from the injection is given by:

where:

$$
Q_{A}=\frac{Q_{I N J} C_{I N J}}{C_{A}-C_{b g}}
$$

$Q_{A} \quad$ is the stream discharge, in $\mathrm{L} / \mathrm{s}$,

$Q_{I N J} \quad$ is the injection rate, in $\mathrm{L} / \mathrm{s}$,

$C_{I N J} \quad$ is the injectate concentration, in $\mathrm{mg} / \mathrm{L}$,

$C_{A} \quad$ is the tracer concentration at plateau, in $\mathrm{mg} / \mathrm{L}$, and

$C_{b g} \quad$ is the naturally occurring background concentration, in $\mathrm{mg} / \mathrm{L}$.

Additional information on tracer-dilution is available in Kimball and others (2002). Previous studies have documented the transport, chemistry, and toxicity of lithium as an inorganic tracer (Bencala and others, 1990; Broshears and others, 1993; Tate and others, 1995; Zellweger, 1994). At higher concen- 
trations than used in this study, bromide has been shown to be toxic, but no effects have been identified at these lower instream concentrations (Flury and Papritz, 1993).

Discharge of an inflow is assigned the difference in discharge between the downstream and upstream stream sites:

$$
Q_{I}=\left(Q_{B}-Q_{A}\right)
$$

where:

$$
\begin{array}{ll}
Q_{I} & \text { is the inflow discharge, in } \mathrm{L} / \mathrm{s}, \\
Q_{B} & \text { is the downstream discharge, in } \mathrm{L} / \mathrm{s}, \text { and } \\
Q_{A} & \text { is the upstream discharge, in } \mathrm{L} / \mathrm{s} .
\end{array}
$$

Dilution of the tracer can occur in several ways. If there is no visible inflow or there are no seeps or springs in a stream segment, the change in stream discharge comes from dispersed, subsurface inflow. If there is a tributary inflow, the change calculated by tracer dilution includes both the surface-water tributary inflow and any dispersed, subsurface inflow that is associated with the tributary or with other sources of subsurface inflow. Individual measurements of tributary surfacewater inflow were not made. In the case where more than one inflow was sampled between stream sites, the discharge increase was divided equally among the inflows. Generally, these were small seeps for which there could be no visual determination of differences in discharge.

\section{Synoptic Sampling and Analytical Methods}

The spatial distribution of metal sources may be characterized by synoptic sampling. Under ideal conditions, samples at all of the sampling locations would be collected simultaneously, providing an instantaneous description of stream water quality along the study reach. Personnel limitations generally preclude simultaneous sample collection, but samples were collected over a relatively short time period (less than 8 hours) to minimize the effect of transient conditions, such as diurnal discharge variations.

Stream and inflow samples were collected at the predetermined locations, beginning at the downstream end of the study reach and ending upstream of the tracer-injection site. This downstream-to-upstream sampling order was followed in order to avoid disturbing the streambed prior to sampling. Inflow and stream sites that were considered well-mixed were sampled by using grab techniques. Sites that were not wellmixed were sampled by equal-width integration (Ward and Harr, 1990). Water temperature was measured on site, and water samples were transported to a central location for further processing. Samples were divided into several $125 \mathrm{~mL}$ bottles with different treatments at the central processing location: a raw (unfiltered) unacidified sample (RU), a raw acidified sample (RA), a filtered unacidified sample (FU), and a filtered acidified sample (FA). At $132 \mathrm{~m}$ an ultra-filtered, acidified (UFA) sample was obtained by using a 10,000 Dalton tangen- tial flow filtration device. This sample was for comparison to the FA sample, similar to comparisons in other streams affected by mine drainage (Kimball and others, 1995).

Specific conductance and $\mathrm{pH}$ were determined from the RU sample within hours of sample collection. In-line $0.45-\mu \mathrm{m}$ capsule filters were used to obtain the FU and FA samples. Metal concentrations for the RA, FA, and UFA treatments were determined by inductively coupled plasma-atomic emission spectrometry/mass spectrometry (Lichte and others, 1987). Anion concentrations were determined from FU samples by using ion chromatography (Brinton and others, 1996; Kimball and others, 1999). Total alkalinity was determined by titration from the FU sample (Barringer and Johnsson, 1989).

Use of both filtered and unfiltered treatments provides two operationally defined concentrations for each metal. Metal concentration from the unfiltered sample (RA) is a measure of the total-recoverable concentration (dissolved + colloidal) and the filtered concentration (FA) is an operational measure of the dissolved metal concentration. Colloidal metal concentrations are defined here as the difference between the total-recoverable (RA) and the filtered metal concentrations (FA) for stream samples (Kimball and others, 1995). Aquatic standards for toxicity in South Dakota are based on $0.45-\mu \mathrm{m}$ filtration.

Measures of accuracy, method detection limits, and parameters for equations to calculate analytical and sampling precision (measured as the coefficient of variation in this report; Davis, 2002), are provided in table 1. Standard reference waters that represented the range of concentrations for each constituent were analyzed at regular intervals during the analytical work (Kimball and others, 1999). For each reference sample, both the mean and the coefficient of variation (CV) were calculated for each constituent, along with the percent difference between that mean and a certified or most probable value. The value for accuracy in table 1 is the median percent difference from these calculations and represents the bias of the analytical determinations. Sampling variability was addressed by collecting replicate samples at two stream sites, 132 and 1, $982 \mathrm{~m}$. The percent difference, calculated as the difference between the replicates divided by the mean of the replicates, was calculated and linearly regressed against the mean concentration for the stream site. This percent difference is analogous to the CV. The slope and intercept for these regressions are listed in table 1 . To determine analytical precision, the CV was regressed as a function of the mean concentration for all the standard reference samples, using a power function of the form:

$$
\text { Precision }(\text { as } C V)=(\text { coefficient })\left(C_{A}\right)^{\text {exponent }}
$$
where:

$$
C_{A} \text { is the mean concentration, in } \mathrm{mg} / \mathrm{L} \text {. }
$$

This form for the calculation fits the data better than a linear regression because, in general, the $\mathrm{CV}$ increases at lower concentrations in a non-linear pattern. The coefficient and exponent for each constituent are listed in table 1. This power 
Table 1. Accuracy, method detection limit, and analytical and sampling precision for synoptic samples

[Only those constituents with an RA concentration substantially different from the FA concentration have an entry for RA; Treatment, FA: filtered, RA, unfiltered; Units: $\mathrm{mg} / \mathrm{L}$, milligrams per liter, $\mu \mathrm{g} / \mathrm{L}$, micrograms per liter; Accuracy, median percent difference from certified standards; Mean of replicate samples, mean concentration using all four sampling replicates;Sampling and analytical precision of mean, in percent; NA, standard reference sample not analyzed]

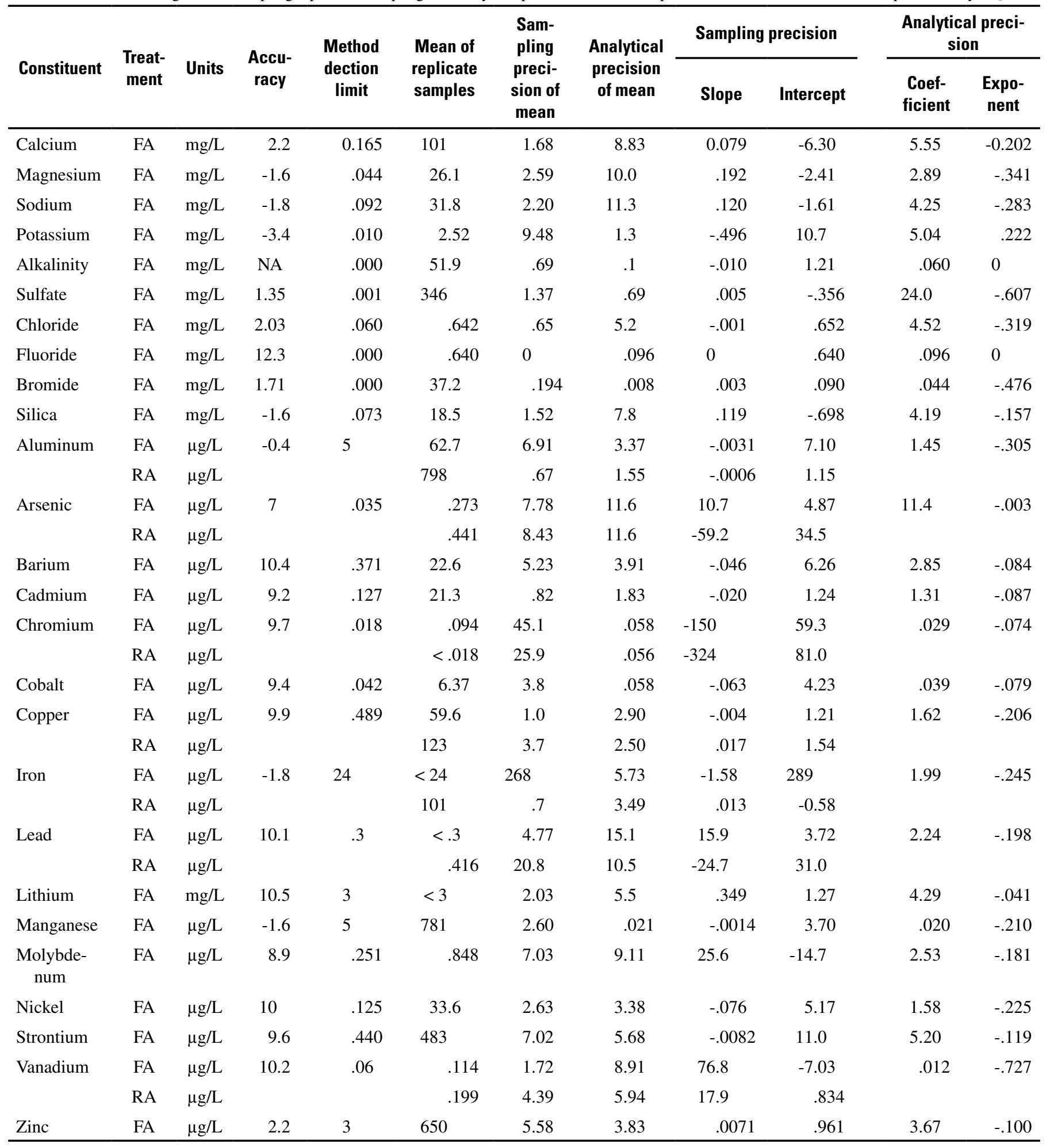


equation was used to calculate the $\Delta C$ term in the load error calculation (see equation 8), where $\Delta C$ was the indicated percentage of the measured concentration for the given sample. Finally, table 1 contains the method detection limit for each constituent.

To compare sampling and analytical variability, the $\mathrm{CV}$ was calculated for sampling and analytical variation by using the mean concentration for all four sampling replicates. Values for the mean sampling replicate, indicated in table 1, represent a typical instream concentration for each constituent, and the sampling and analytical CV of the mean provides the comparison.

\section{Constituent Loads}

Mass load was calculated for each stream sampling site along the study reach as:

where:

$$
M_{A}=C_{A} Q_{A}(0.0864)
$$

$M_{A}$ is the constituent load, or mass flux, at location A, in $\mathrm{kg} / \mathrm{day}$,

$C_{A} \quad$ is the concentration of the selected constituent at location $\mathrm{A}$, in $\mathrm{mg} / \mathrm{L}$,

$Q_{A} \quad$ is the discharge at location $\mathrm{A}$, in $\mathrm{L} / \mathrm{s}$, and

0.0864 is the conversion factor from $\mathrm{mg} / \mathrm{s}$ to $\mathrm{kg} / \mathrm{day}$.

Total sampled instream load is calculated from the total-recoverable concentration of the constituent; dissolved and colloidal loads were calculated individually for some metals. The longitudinal profiles of sampled instream loads (total or dissolved plus colloidal) constitute the basic data from the mass-loading study.

For each stream segment, the change in load between a pair of stream sites accounts for the gain or loss of constituent load for that segment. The change in load for the segment starting at location $A$ and ending at location $B$ is:

$$
\Delta M_{S}=\left(C_{B} Q_{B}-C_{A} Q_{A}\right)(0.0864)
$$

where:

$$
\begin{gathered}
\Delta M_{S} \quad \begin{array}{l}
\text { is the change in sampled instream load from } \\
\text { location } A \text { to } B, \text { in } \mathrm{kg} / \mathrm{day},
\end{array} \\
C_{B} \quad \begin{array}{l}
\text { is the concentration of the selected constituent at } \\
\text { location } B, \text { in } \mathrm{mg} / \mathrm{L},
\end{array} \\
Q_{B} \quad \text { is the discharge at location } B, \text { in } \mathrm{L} / \mathrm{s}, \text { and } \\
C_{A}, Q_{A} \text {, and } 0.0864 \text { are defined in equation } 4 .
\end{gathered}
$$

Gains in constituent load ( $\Delta M_{S}$ is greater than zero) imply that there is a source that contributes to the stream between the two stream sites. However, there could be instream processes that reduce the net gain; thus, the measured change may not indicate the total magnitude of the source. Instream load also can decrease within a stream segment $\left(\Delta M_{S}\right.$ is less than zero), meaning that there is a net loss of the constituent as a result of physical, chemical, or biological processes. A net loss does not preclude the presence of a source of loading for a particular stream segment, but it does preclude quantifying the magnitude of that source. Summing all the increases in load between sampling sites along the study reach (positive values of $\Delta M_{S}$ ) leads to the cumulative instream load. At the end of the study reach, the cumulative instream load is the best estimate of the total load added to the stream but is likely a minimum estimate because it only measures the net loading between sites and does not account for metal loads added to and then lost from the water column within individual stream segments.

For those segments that include one or more sampled inflows, it is possible to evaluate how well the sampled inflow accounts for the instream changes. If stream sites $A$ and $B$ bracket one inflow sample, location $I$ :

$$
\Delta M_{I}=C_{I}\left(Q_{B}-Q_{A}\right)(0.0864)
$$

where:

$$
\begin{gathered}
\Delta M_{I} \quad \begin{array}{l}
\text { is the sampled inflow load between location } A \text { and } \\
B, \text { in } \mathrm{kg} / \mathrm{day},
\end{array} \\
C_{I} \quad \begin{array}{l}
\text { is the concentration of the selected constituent at } \\
\text { inflow location } I, \text { in } \mathrm{mg} / \mathrm{L}, \text { and }
\end{array} \\
Q_{A}, Q_{B}, 0.0864 \text { are defined in equations } 4 \text { and } 5 .
\end{gathered}
$$

Equation 6 assumes that the entire increase in discharge between locations $A$ and $B$ is contributed by the sampled inflow and that $C_{I}$ represents the concentration of the solute for all the water entering the stream between locations $A$ and $B\left(Q_{B}-Q_{A}\right)$. Where more than one inflow was sampled in a stream segment, the overall change in discharge was divided by the number of inflows and that fraction was multiplied by the individual concentrations of the inflow samples, and the parts were summed to get a value for $\Delta M_{r}$. Summing the calculated inflow loads along the study reach produces a longitudinal profile of the cumulative inflow load that can be compared to the cumulative instream load. Commonly in streams affected by mine drainage, the cumulative instream load is greater than cumulative inflow load. This result can indicate important areas of unsampled inflow, defined as:

$$
\Delta M_{U}=\Delta M_{S}-\Delta M_{I}
$$

where:

$$
\begin{aligned}
& \Delta M_{U} \quad \text { is unsampled inflow load between locations } A \text { and } \\
& B, \text { in } \mathrm{kg} / \mathrm{day}, \text { and } \\
& \Delta M_{S}, \Delta M_{I} \text { are defined in equations } 5 \text { and } 6 .
\end{aligned}
$$

In the case that $\Delta M_{I}$ is greater than $\Delta M_{S}$ for a given stream segment, two explanations are possible, but they cannot be distinguished from the experimental data alone. First, it could mean that the solute is lost from the water column through chemical or biological processes, resulting in a smaller net value of $\Delta M_{S}$. Second, it could mean that the sampled inflow concen- 
tration, $\mathrm{C}_{l}$, was not representative of all the water entering the stream segment. Despite these limitations, the quantification of $\Delta M_{S}, \Delta M_{I}$, and $\Delta M_{U}$ provides useful information for understanding the dynamics of solute loading to the stream (Bencala and Ortiz, 1999). Unsampled inflow can be calculated for individual stream segments, or for the entire study reach. A negative value for the entire study reach does not preclude positive values for some individual stream segments.

In considering estimates of stream discharge and metal concentration at each stream site, it is possible to predict an error for the change in load along a stream segment. The error is determined by the precision of both discharge and chemical measurements (Taylor, 1997), according to the equation (McKinnon, 2002):

$$
\text { Load error }=\sqrt{Q_{A}^{2} \Delta C_{A}^{2}+C_{A}^{2} \Delta Q_{A}^{2}}(0.0864)
$$

where:

$$
\begin{gathered}
\Delta C_{A} \quad \text { is the concentration error at site } A, \text { in } \mathrm{mg} / \mathrm{L}, \\
\Delta Q_{A} \quad \text { is the discharge error at site } A, \text { and } \\
Q_{A}, C_{A} \text {, and } 0.0864 \text { are defined in equation } 4 .
\end{gathered}
$$

The value of $\Delta C_{A}$ is based on the analytical $\mathrm{CV}$ for each constituent. The value of $\Delta Q_{A}$ is based on the $\mathrm{CV}$ for the tracer concentration at the transport sites during the period of synoptic sampling. This results in a value of $\mathrm{CV}$ as a function of discharge, calculated for each value of $Q$. Load error is calculated for the upstream sampling site of each stream segment and compared to the change in load for the stream segment, $\Delta M_{S}$. If the absolute value of $\Delta M_{S}$ is greater than the load error, then there has been a significant change in load. Only the values of $\Delta M_{S}$ that are greater than the load error are included in the longitudinal profiles of sampled instream load and the cumulative instream load.

\section{Cluster Analysis}

An important objective of synoptic sampling is to recognize patterns or chemical characteristics among samples that can indicate the different sources of solutes. As water interacts with different mineral assemblages, it obtains a distinct chemical signature. Distinctions among inflow groups may lead to the interpretation of differences in drainage from a specific mineralogical assemblage.

A method of cluster analysis called partitioning around medoids was used to evaluate distinctions among the samples (Kaufman and Rousseeuw, 1990). The method operates on a dissimilarity index by computing the number of representative objects (medoids) specified by the user. Using Euclidian distance as a measure of similarity, each sample is then assigned to the cluster of the nearest medoid. Choosing the number of groups for inflows and stream sites was guided by the ability to explain a grouping in terms of geologic, hydrologic, or geo- chemical information. Any cluster that could not be explained in relatively simple physical or chemical terms was not added.

To emphasize the linear relations among variables, the chemical concentration of each constituent, expressed in millimoles per liter, was log transformed to improve correlations that may be related to the stoichiometry of particular chemical reactions and mineral equilibrium constraints. Total-recoverable concentrations were not determined for all inflow samples because many sampling locations were small pits near the stream where it was easy to stir up mud into the sample. Thus, only filtered concentrations were used in the cluster analysis for inflow samples. Both filtered and colloidal concentrations (total-recoverable less filtered) were available for stream samples and both were used for the cluster analysis. Changes in colloidal concentrations of stream samples often indicate important distinctions along the study reach (Kimball and others, 2003; Kimball and others, 1995).

\section{Field-Scale Experiment}

A mass-loading study was conducted during June 26-27, 2003, to investigate a 2,523-m reach along Strawberry Creek (fig. 1). Stream and inflow sampling sites were chosen during a reconnaissance of the stream reach. The location of stream sampling sites defined 25 stream segments along Strawberry Creek. These segments are referenced by the name of the stream sampling site at the downstream end of the segment. Twenty-six inflow sites werre sampled along the study reach. Additional sampling sites were located in Bear Butte Creek upstream and downstream from Strawberry Creek, in Ruby Gulch, downstream from Ruby Gulch, and at the USGS streamflow-gaging station Bear Butte Creek near Galena, South Dakota (06437200). Details of the sampling sites are listed in table 2 . The site at $12 \mathrm{~m}$ is listed as a left-bank inflow because it was the end of the discharge pipe, but it also is considered the end of the most upstream stream segment, representing the input from the Gilt Edge mine. Because there was essentially no discharge upstream from the pipe at $12 \mathrm{~m}$, the sample at $12 \mathrm{~m}$ was considered to be the background site, and the tracer was injected just downstream from where the pipe discharged.

\section{Discharge}

A lithium bromide tracer was injected just downstream from the pipe at $12 \mathrm{~m}$ that discharged the discharge of Strawberry Creek from the Gilt Edge mine site (fig. 1). Samples of the injectate solution were collected several times throughout the injection period to measure rate and concentration of the injection. These samples indicated that variations in the mass flux of lithium bromide to the stream occurred. These variations are accounted for in the calculation of discharge (table 3 ). The injection rate varied from 0.00310 to $0.00363 \mathrm{~L} / \mathrm{s}$ and the injectate concentration varied from 65,528 to 68,730 
Table 2. Sample identification, source, downstream distance, description, site number, $\mathrm{pH}$, specific conductance, and cluster analysis group for synoptic samples, Strawberry and Bear Butte Creeks, South Dakota

[Source: LBI, left-bank inflow; S, stream; RBI, right-bank inflow; $\mu$ S/cm, microsiemens per centimeter at 25 degrees Celsius; NA, not included in analysis]

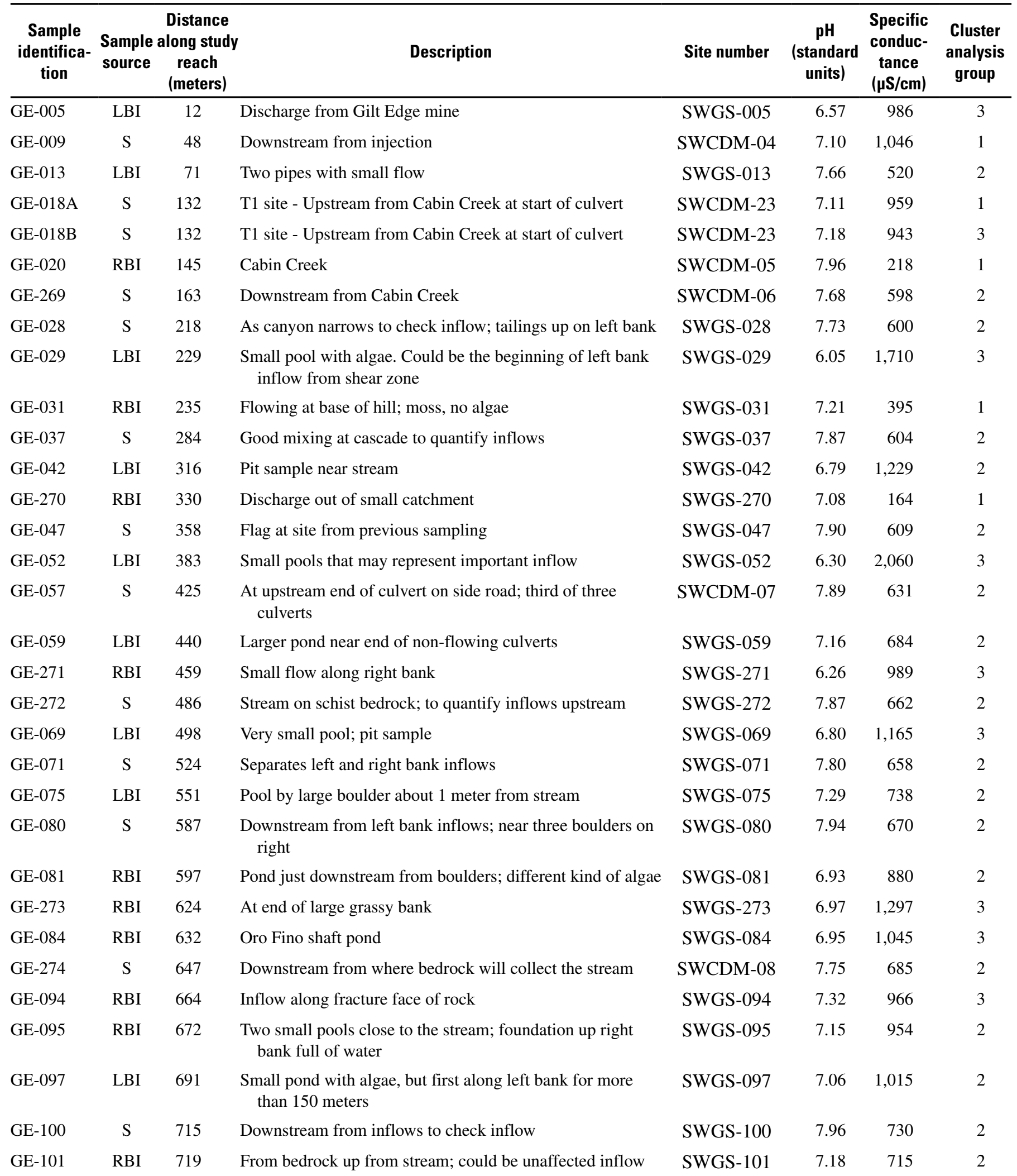


Table 2. Sample identification, source, downstream distance, description, site number, pH, specific conductance, and cluster analysis group for synoptic samples, Strawberry and Bear Butte Creeks, South Dakota-Continued

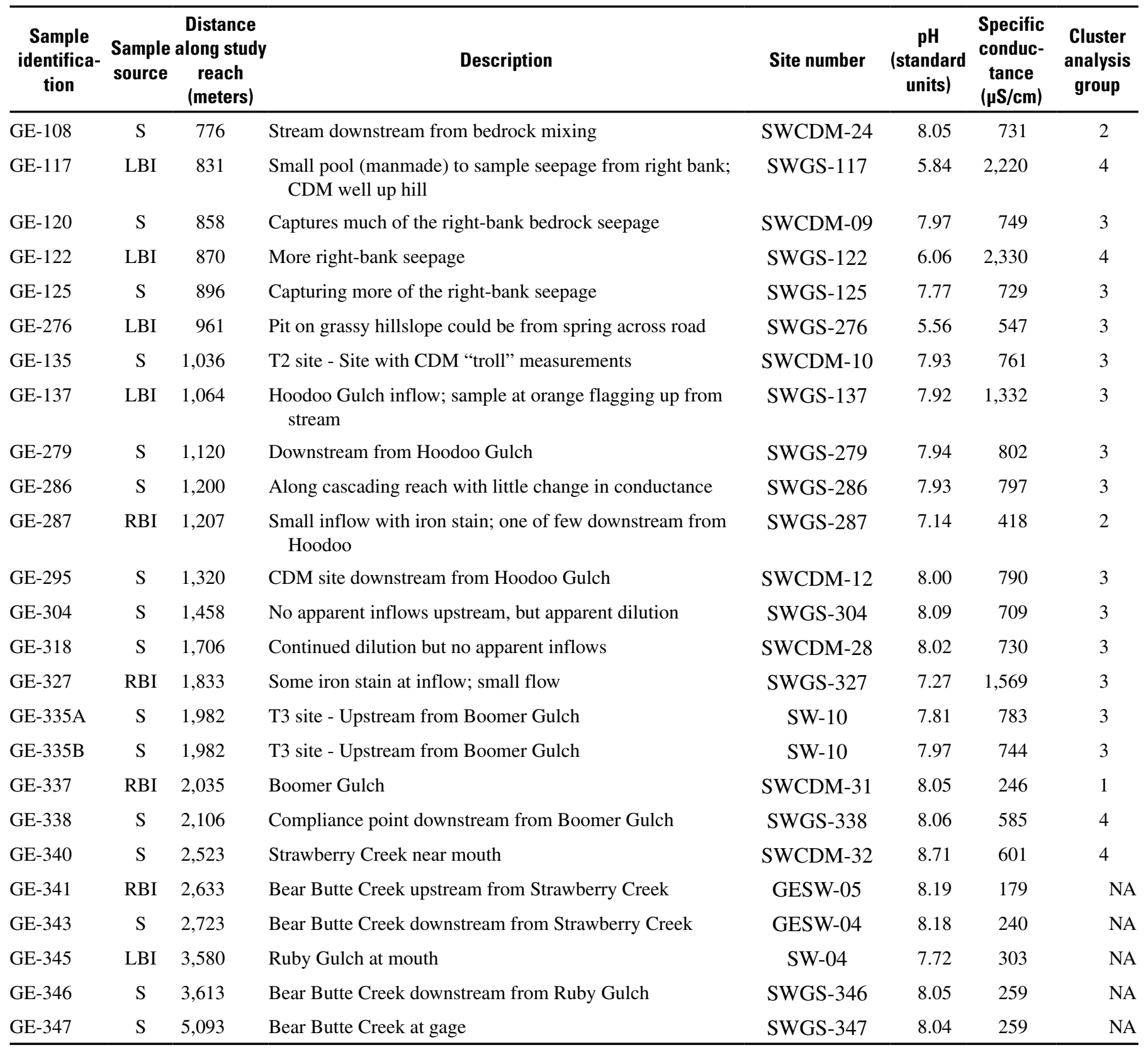

$\mathrm{mg} / \mathrm{L}$ as bromide. During the tracer injection, injected bromide concentrations were substantially higher than ambient background concentrations (fig. 2). Five inflows had bromide concentrations comparable to the stream concentration and likely contained some stream water. Samples from these sites were not used to calculate the background bromide concentration. Background concentrations of bromide in the other 21 sampled inflows had an average of $0.06 \mathrm{mg} / \mathrm{L}$. The background concentration of bromide upstream from the injection was $0.03 \mathrm{mg} / \mathrm{L}$, and this value was used as the background concentration in equation 1 along with the sampled bromide concentrations to calculate discharge. Variation of bromide concentration along the study reach and the calculated discharge are shown in figure 2.

During the study, discharge increased along Strawberry Creek from 2.6 L/s to $27.9 \mathrm{~L} / \mathrm{s}$, an increase of $25.3 \mathrm{~L} / \mathrm{s}$. All but a small fraction of the initial $2.6 \mathrm{~L} / \mathrm{s}$ was from the Gilt Edge mine discharge, accounted for at $12 \mathrm{~m}$. Three tributaries added discharge to Strawberry Creek. Cabin Creek added 3.45 L/s, Hoodoo Creek added $0.83 \mathrm{~L} / \mathrm{s}$, and Boomer Gulch added 9.73 $\mathrm{L} / \mathrm{s}$. The additional increase in discharge along Strawberry Creek, after accounting for these three tributaries, was 11.3 $\mathrm{L} / \mathrm{s}$. The greatest rate of inflow (per meter of stream) was in the area near the Oro Fino shaft, in the area indicated by a hatched box in figure 2. This is the area where the Selway NE 
Table 3. Bromide tracer, pump rate, injectate concentration, and calculated discharge for synoptic stream samples, Strawberry Creek, South Dakota

\begin{tabular}{|c|c|c|c|c|}
\hline $\begin{array}{l}\text { Distance along study } \\
\text { reach } \\
\text { (meters) }\end{array}$ & $\begin{array}{l}\text { Concentration of bro- } \\
\text { mide in steam water } \\
\text { (milligrams per liter) }\end{array}$ & $\begin{array}{l}\text { Pump rate } \\
\text { (liters } \\
\text { per second) }\end{array}$ & $\begin{array}{l}\text { Concentration of injectate } \\
\text { (milligrams per liter, } \\
\text { as bromide) }\end{array}$ & $\begin{array}{c}\text { Calculated discharge from } \\
\text { equation } 1 \\
\text { (liters per second) }\end{array}$ \\
\hline 48 & 74.8 & 0.00310 & 62,528 & 2.59 \\
\hline 132 & 59.2 & .00310 & 62,528 & 3.28 \\
\hline 163 & 28.9 & .00310 & 62,528 & 6.73 \\
\hline 218 & 28.6 & .00310 & 62,528 & 6.78 \\
\hline 284 & 27.8 & .00310 & 62,528 & 6.98 \\
\hline 358 & 27.4 & .00314 & 63,278 & 7.25 \\
\hline 425 & 26.8 & .00319 & 63,957 & 7.63 \\
\hline 486 & 26.0 & .00323 & 64,575 & 8.03 \\
\hline 524 & 25.5 & .00327 & 64,960 & 8.34 \\
\hline 587 & 24.9 & .00331 & 65,599 & 8.74 \\
\hline 647 & 22.7 & .00335 & 66,207 & 9.81 \\
\hline 715 & 21.0 & .00350 & 66,896 & 11.2 \\
\hline 776 & 20.6 & .00351 & 67,514 & 11.5 \\
\hline 858 & 20.6 & .00357 & 68,345 & 11.9 \\
\hline 896 & 20.9 & .00363 & 68,730 & 12.0 \\
\hline 1,036 & 20.6 & .00363 & 68,730 & 12.1 \\
\hline 1,120 & 19.2 & .00363 & 68,730 & 13.0 \\
\hline 1,200 & 18.6 & .00363 & 68,730 & 13.5 \\
\hline 1,320 & 18.3 & .00363 & 68,730 & 13.6 \\
\hline 1,458 & 17.4 & .00363 & 68,730 & 14.3 \\
\hline 1,706 & 16.7 & .00363 & 68,730 & 14.9 \\
\hline 1,982 & 15.2 & .00363 & 68,730 & 16.5 \\
\hline 2,106 & 9.55 & .00363 & 68,730 & 26.2 \\
\hline 2,523 & 8.96 & .00363 & 68,730 & 27.9 \\
\hline
\end{tabular}

shear zone intersects the stream; this shear zone could be a connection between the mine pool and Strawberry Creek (fig. 1). The remaining ground-water inflow appears evenly dispersed along the study reach. Upstream from Hoodoo Gulch, most of this inflow was visible as seeps near stream level, while downstream from Hoodoo Gulch less of the inflow was visible. Discharge of Bear Butte Creek was $122 \mathrm{~L} / \mathrm{s}$ upstream from Strawberry Creek and increased to $192 \mathrm{~L} / \mathrm{s}$ at the gaging station about 2,000 m downstream.

As noted, ground-water discharge might have been temporarily high as a result of rain storms in the preceding 24 hours. A concentration history of the tracer was obtained by using auto-samplers at three sites along the stream. These data help to evaluate if the rain could have resulted in transient conditions during the synoptic sampling (fig. 3). The concentration of bromide at site $\mathrm{T} 1$ varied about 6 percent during the plateau, with a small increase from the beginning of the plateau period until 03:00 hrs on June 27, 2003 (fig. 3A). This increase in bromide could indicate a slight decrease in dis- charge after the rain. At sites T2 and T3, bromide concentration also increased during the period before synoptic sampling, which also could suggest a small, steady decrease in discharge (fig. 3A). During the synoptic sampling, however, bromide concentration at all three sites was essentially constant. Sulfate concentration (fig. 3B) only varied by about 3 percent during the plateau period at the most upstream transport site (T1, at $132 \mathrm{~m}$ ), which does not suggest a change from recession of storm discharge. At transport sites T2 and T3, there was little variation in sulfate concentration. Subsequent variations in sulfate concentration occurred but were not related to a transient condition after the storm.

\section{Chemical Characterization of Synoptic Samples}

Synoptic sampling provided detailed spatial information about the chemical changes that occurred in each stream segment along Strawberry Creek. Results of chemical analyses for 


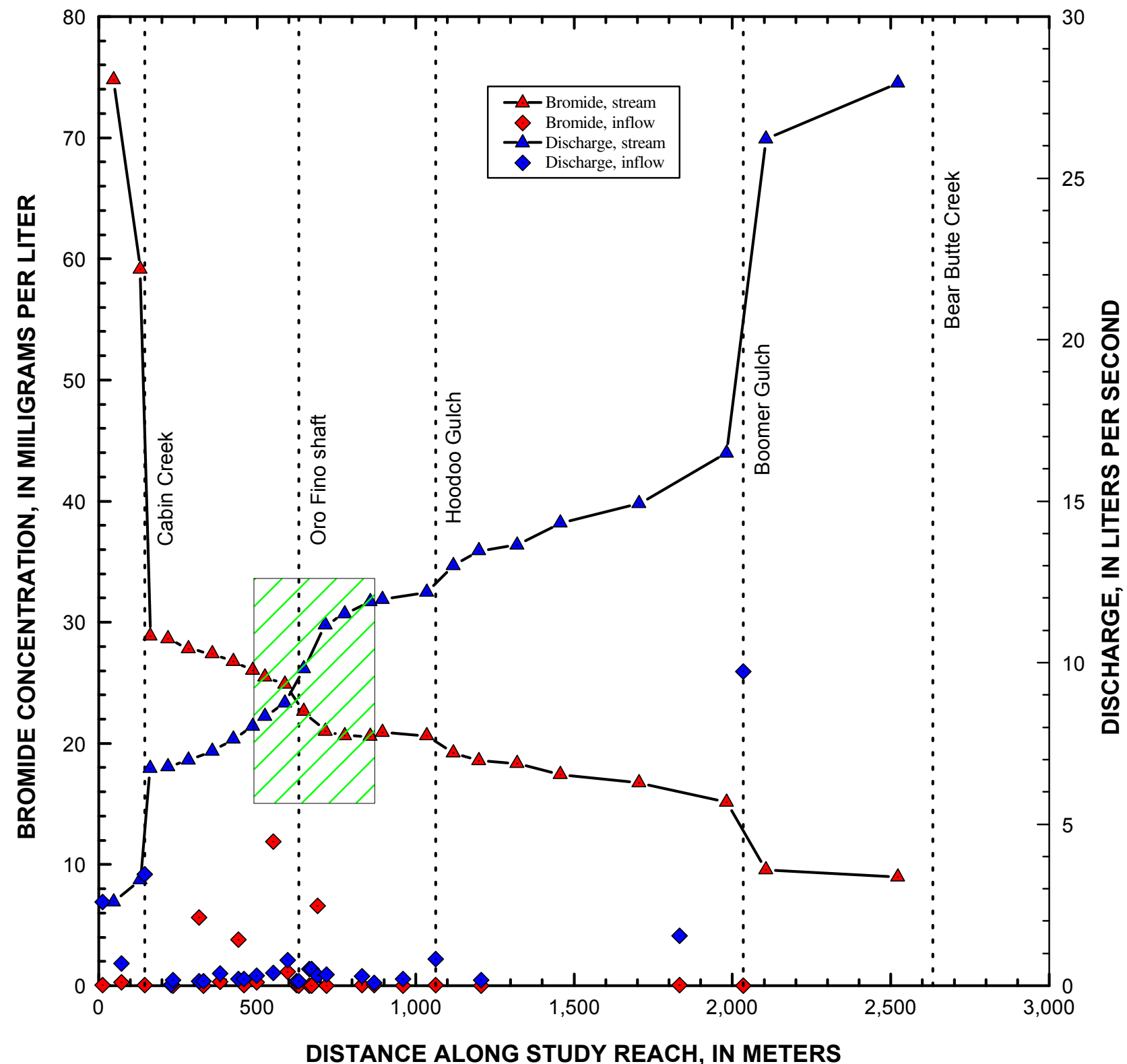

Figure 2. Variation of bromide concentration and calculated discharge with distance along the study reach, Strawberry Creek, South Dakota.

all of the synoptic samples are listed for major ions (table 4, located at the back of the report) and for trace elements (table 5 located at the back of the report). Accuracy, and measures of sampling and analytical precision are listed in table 1. For all stream samples there are at least two rows of data-the first row for the FA, or filtered sample, and the second for the RA, or total-recoverable sample. For many inflow samples only an FA row is listed in the table because these samples were collected from shallow pits dug next to the stream and the RA samples contained stirred up mud, which invalidates the sample. Inflow samples with both FA and RA concentrations generally were free flowing to the stream, and not bailed from pits. Colloidal concentrations that are plotted in figures and used in the loading calculations were calculated from these data as the difference between the RA and the FA concentrations. Occasionally, the FA concentration was greater than the RA concentration, but in all cases the two concentrations were within analytical precision. When this occurred, the FA concentration was used for both the filtered and total-recoverable concentrations and the colloidal concentration was considered 


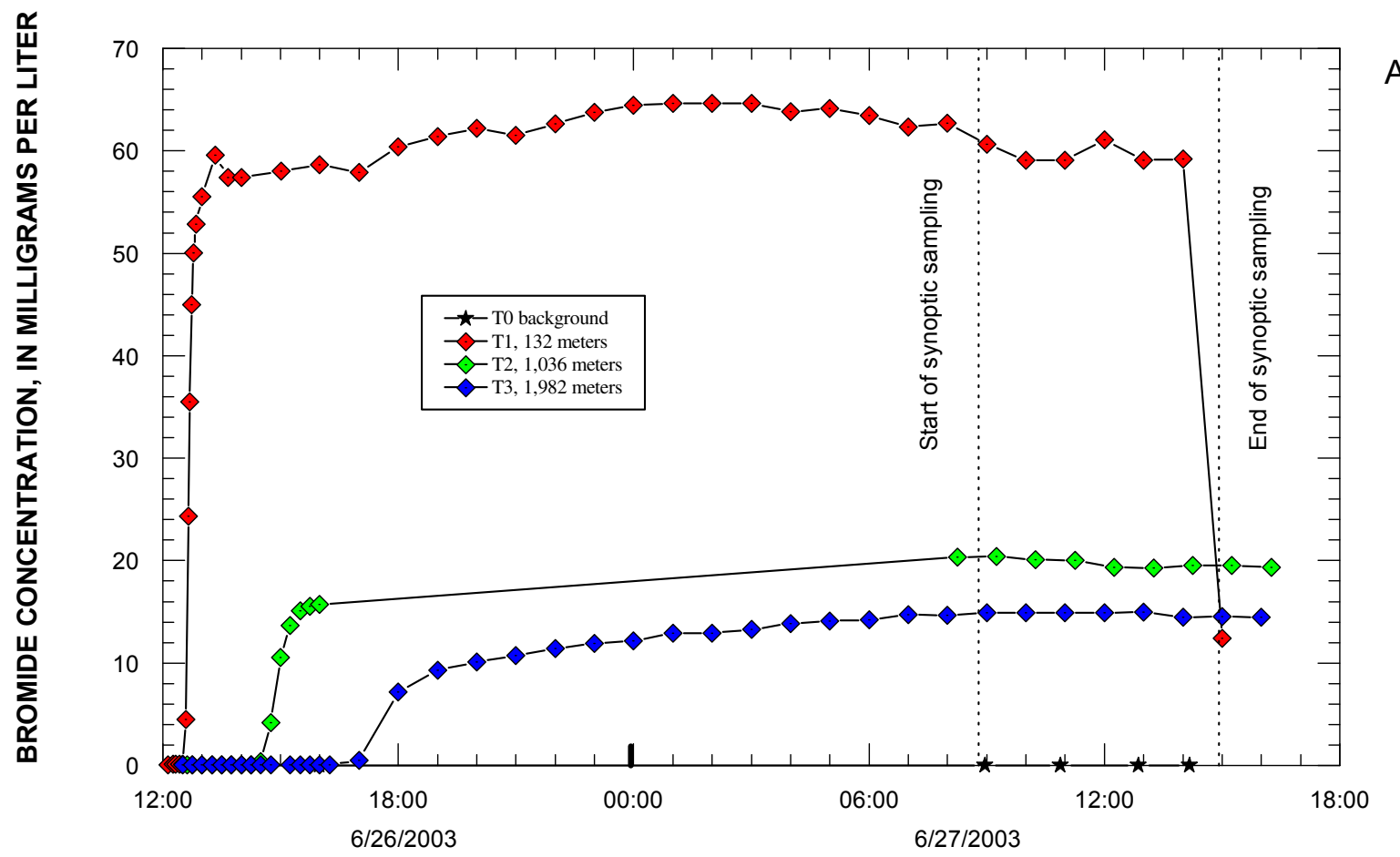

A

TIME, IN HOURS

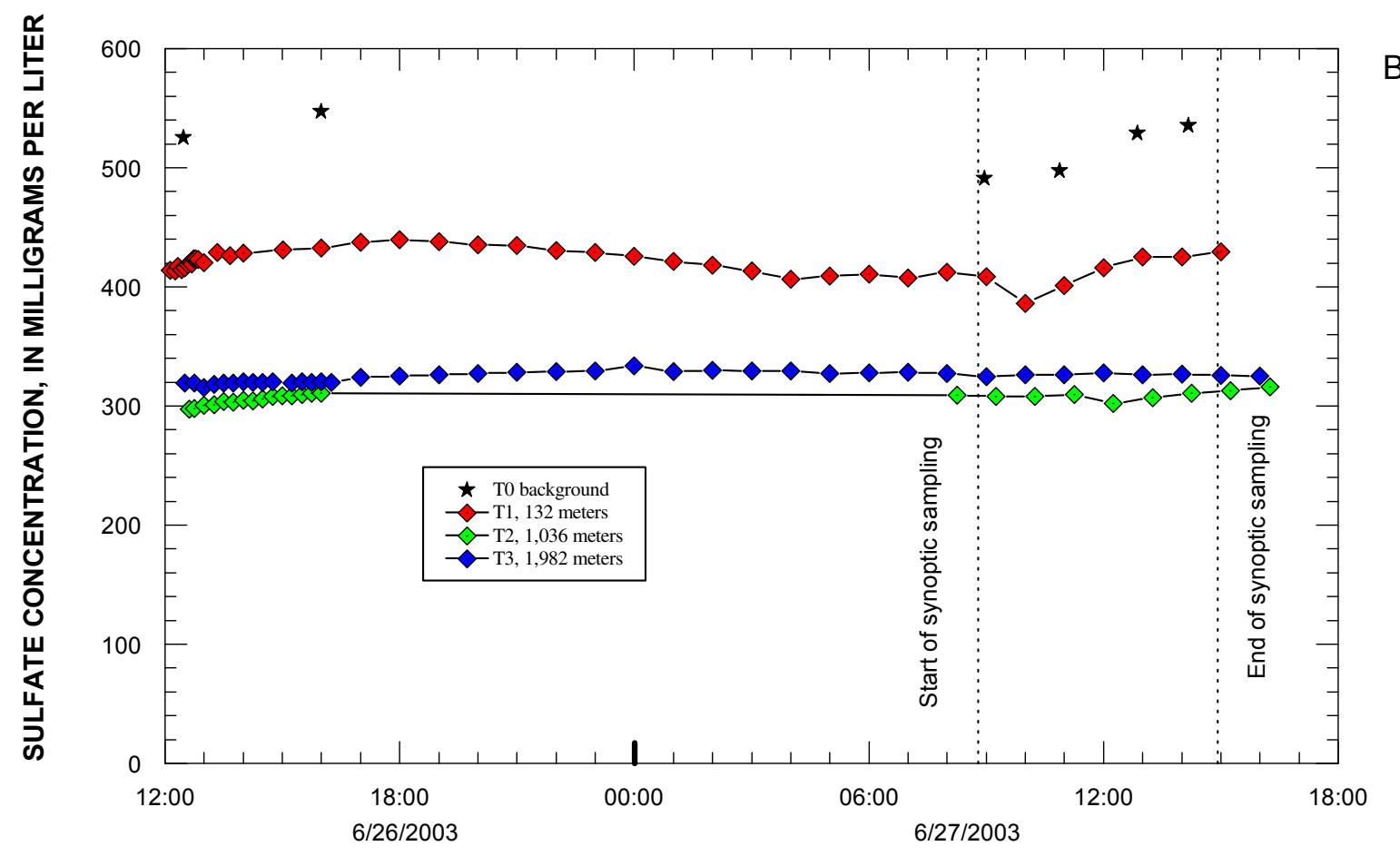

TIME, IN HOURS

Figure 3. Variation of (A) bromide and (B) sulfate concentrations with time during the injection period, Strawberry Creek, South Dakota. 
less than detection. Field replicates of stream samples at 132 and $1,982 \mathrm{~m}$ are distinguished in the tables by different sample times.

Distinct differences in concentrations between UFA (ultra-filtered) and FA (0.45- $\mu \mathrm{m}$ filtered) samples have been noted in streams affected by acid mine drainage (Benoit and Rozan, 1999; Buffle and Leppard, 1995; Church and others, 1997; Hoffman and others, 1981; Kimball and others, 1995; Morel and Gschwend, 1987; Schemel and others, 2000; Sullivan and Drever, 2001). The UFA treatment was used on the sample at $163 \mathrm{~m}$ to evaluate if ultrafiltration was necessary for the stream samples collected from Strawberry Creek. The site at $163 \mathrm{~m}$ was chosen for the comparison because it was downstream from Cabin Creek, a neutral inflow diluting the more acidic discharge from Gilt Edge mine, and a site likely to contain colloids. The results for the UFA treatment clearly indicate colloids present in the stream at $163 \mathrm{~m}$. Calculations done using the UFA concentration to calculate a colloidal concentration for aluminum gives $617 \mu \mathrm{g} / \mathrm{L}$ ( 87 percent of the total aluminum). Calculations done using the FA concentration gives a colloidal concentration of $589 \mu \mathrm{g} / \mathrm{L}$ ( 83 percent of the total aluminum). Because both UFA and FA concentrations of iron were less than the method detection limit, there is no difference in the colloidal concentration calculated. The colloidal concentration was essentially 100 percent of the iron in the stream (table 5). Copper, strontium, vanadium, and zinc also had UFA concentrations less than FA and RA concentrations. Copper and zinc, in particular, tend to sorb to the iron colloids in mixing zones (Schemel and others, 2000). Of the remaining trace metals, five had UFA concentrations that were less than RA concentrations, but slightly greater than FA concentrations; three had UFA concentrations that were greater than both the FA and RA concentrations, but generally by only a small amount. Thus, at this relatively high $\mathrm{pH}$, it should be reasonable to use FA concentrations for an operationally defined dissolved concentration, keeping in mind that the actual dissolved concentration may be slightly lower and that the colloidal concentrations may be slightly higher for those trace elements that are commonly part of colloids in mine drainage.

\section{Inflows}

These chemical data distinguish four groups of inflow samples and four groups of stream samples. An assignment, made by cluster analysis, to one of the stream or inflow groups is listed for each sample in table 2. Inflow groups are chemically distinct and for inflow group 1 through inflow group 4, most concentrations vary from low to high (table 6). A variation from low to high concentrations is best seen by increases in the concentrations of sulfate, with median concentrations increasing from 38.4 to $1,360 \mathrm{mg} / \mathrm{L}$; iron, with median concentrations increasing from less than detection to $34,800 \mu \mathrm{g} / \mathrm{L}$; manganese, increasing from 7.97 to 6,490 $\mu \mathrm{g} / \mathrm{L}$; and zinc, increasing from 46.7 to $2,540 \mu \mathrm{g} / \mathrm{L}$ (table 6). Higher concentrations most likely are an impact of mining that results from mixing or from water-rock interaction. Whichever process is responsible, concentrations of samples in the inflow groups represent varying degrees of mining impact. The "least affected" waters are part of inflow group 1, and the "most affected" waters are part of inflow group 4. Inflow group 1 includes right-bank sources, opposite from the Gilt Edge mine, including Cabin Creek (145 m), Boomer Gulch (2,035 $\mathrm{m}$ ), and right-bank inflows downstream from Cabin Creek at 858 and $896 \mathrm{~m}$ (table 2). Among those samples substantially affected (inflow group 3) are the discharge from the Gilt Edge mine $(12 \mathrm{~m})$, the Oro Fino shaft inflow $(632 \mathrm{~m})$, and Hoodoo Gulch $(1,064 \mathrm{~m})$. Samples of inflow groups 2 and 3 mostly occur from the beginning of the study reach to $776 \mathrm{~m}$ (fig. 4). Samples of inflow group 3 , which have higher concentrations, include left bank inflows at $229 \mathrm{~m}, 383 \mathrm{~m}$, and $498 \mathrm{~m}$ that could be influenced by water from the Sunday pit lake through the Sunday shear zone (fig. 1). Two samples "most affected" by mining (inflow group 4) are left-bank samples at $831 \mathrm{~m}$ and $870 \mathrm{~m}$. They were chemically distinct from other inflow samples, having the highest concentrations of sulfate, most metals, and lower $\mathrm{pH}$ (fig. 4). These chemically distinct inflows occurred about $200 \mathrm{~m}$ downstream from where the Selway northeast shear zone may connect the Langley pit area with Strawberry Creek and are near the Selway northwest shear zone (fig. 1).

To evaluate the possibility of mixing, the chemistry of the Sunday pit lake (U.S. Environmental Protection Agency, 2005) is compared to the synoptic inflow samples (figs. 5A and 5B). The sum of dissolved base-metal concentrations is highest in waters with lower $\mathrm{pH}$ (Ficklin and others, 1992). The trend of the samples that are most affected by mining (inflow groups 3 and 4) is in the direction of the Sunday pit lake sample, which is consistent with a process of mixing (fig. 5A). The Sunday pit lake sample also plots with a pattern that is consistent with mixing, with respect to manganese and sulfate concentrations (fig. 5B). Thus, mixing with the Sunday pit lake water could explain the chemical variation among many inflow samples. Another possible source of solutes for samples of inflow groups 2 and 3 could be the discharge of water from the alluvium that has interacted with historical tailings. Efforts have been made, however to remove the tailings material upstream from the Oro Fino shaft (U.S. Environmental Protection Agency, 2005).

\section{Stream}

Chemical distinctions among the four groups of steam samples represent the sequential downstream changes that result from the contribution of particular inflows along the study reach. Median concentrations of constituents are compared for the stream groups in table 7. Discharge from the Gilt Edge mine (stream group 1; table 7) established the initial chemical character of the stream. Chemical changes then occurred at $145 \mathrm{~m}$ with the inflow of Cabin Creek (change to stream group 2), at $776 \mathrm{~m}$ after the group 4 inflow at $831 \mathrm{~m}$ 
Table 6. Median values of dissolved concentrations for selected constituents for inflow groups defined by cluster analysis.

$[\mathrm{mg} / \mathrm{L}$ milligrams per liter, $\mu \mathrm{g} / \mathrm{L}$, micrograms per liter, $<$ less than $]$

\begin{tabular}{|c|c|c|c|c|}
\hline \multirow{3}{*}{ Constituent } & \multicolumn{4}{|c|}{ Inflow group } \\
\hline & 1 & 2 & 3 & 4 \\
\hline & Least affected & Affected & $\begin{array}{c}\text { Substantially } \\
\text { affected }\end{array}$ & Most affected \\
\hline Number of samples & 4 & 9 & 10 & 2 \\
\hline $\mathrm{pH}$, in standard units & 7.58 & 7.15 & 6.74 & 5.95 \\
\hline Calcium, mg/L & 35.6 & 84.3 & 158 & 357 \\
\hline Magnesium, mg/L & 6.00 & 17.6 & 31.3 & 105 \\
\hline Sodium, mg/L & 2.65 & 52.4 & 90.5 & 31.1 \\
\hline Alkalinity, as $\mathrm{CaCO} 3, \mathrm{mg} / \mathrm{L}$ & 86.5 & 97.1 & 74.2 & 10.6 \\
\hline Sulfate, mg/L & 38.4 & 277 & 617 & 1,360 \\
\hline Chloride, mg/L & 2.82 & 11.6 & 8.34 & 2.34 \\
\hline Silica, mg/L & 12.4 & 13.9 & 18.7 & 32.6 \\
\hline Aluminum, $\mu \mathrm{g} / \mathrm{L}$ & 20.5 & 73.7 & 156 & 194 \\
\hline Arsenic, $\mu \mathrm{g} / \mathrm{L}$ & .530 & .550 & .823 & .865 \\
\hline Barium, $\mu \mathrm{g} / \mathrm{L}$ & 11.3 & 21.3 & 31.6 & 27.3 \\
\hline Cadmium, $\mu \mathrm{g} / \mathrm{L}$ & $<.13$ & .594 & .722 & 13.5 \\
\hline Chromium, $\mu \mathrm{g} / \mathrm{L}$ & .073 & .084 & .094 & .045 \\
\hline Cobalt, $\mu \mathrm{g} / \mathrm{L}$ & .140 & 1.73 & 2.21 & 148 \\
\hline Copper, $\mu \mathrm{g} / \mathrm{L}$ & 1.03 & 4.84 & 7.36 & 17.1 \\
\hline Iron, $\mu \mathrm{g} / \mathrm{L}$ & $<24$ & 186 & 280 & 34,800 \\
\hline Lead, $\mu \mathrm{g} / \mathrm{L}$ & $<.3$ & $<.3$ & $<.3$ & $<.3$ \\
\hline Manganese, $\mu \mathrm{g} / \mathrm{L}$ & 7.97 & 47.1 & 388 & 6,490 \\
\hline Molybdenum, $\mu \mathrm{g} / \mathrm{L}$ & .343 & .646 & .514 & .270 \\
\hline Nickel, $\mu \mathrm{g} / \mathrm{L}$ & .210 & 3.30 & 13.5 & 355 \\
\hline Strontium, $\mu \mathrm{g} / \mathrm{L}$ & 183 & 277 & 583 & 1,020 \\
\hline Vanadium, $\mu \mathrm{g} / \mathrm{L}$ & .338 & .094 & .106 & $<.06$ \\
\hline Zinc, $\mu \mathrm{g} / \mathrm{L}$ & 46.7 & 77.1 & 154 & 2,540 \\
\hline
\end{tabular}

(change to stream group 3), and at 2,035 $\mathrm{m}$ with the inflow of Boomer Gulch (change to stream group 4).

Stream samples of stream group 1, downstream from the Gilt Edge mine discharge, had relatively low $\mathrm{pH}$ (fig. 4A; table 7), with a median of 6.94. Downstream from Cabin Creek, the median $\mathrm{pH}$ increased to 7.86 and remained mostly the same until the inflow of Boomer Gulch that raised the $\mathrm{pH}$ to a median of 8.39 in stream group 4. Chemical distinctions also are evident in the variation in sulfate concentration (fig. 4B). The highest instream concentrations occurred upstream from Cabin Creek, with a median concentration of $438 \mathrm{mg} / \mathrm{L}$ in stream group 1. Sulfate concentration was diluted by Cabin Creek to a median of $220 \mathrm{mg} / \mathrm{L}$ in stream group 2. Downstream from Cabin Creek the sulfate concentrations steadily increased from the many inflows that had higher sulfate concentrations, reaching a median concentration of $288 \mathrm{mg} / \mathrm{L}$ for stream group 3. Downstream from Boomer Gulch, the sulfate concentration was diluted to a median of $194 \mathrm{mg} / \mathrm{L}$.
Iron concentrations had some very distinct changes. Although dissolved iron concentrations generally were near the lower limit of detection, colloidal iron concentrations were measurable along the study reach (fig. 6A). Colloidal iron concentration increased substantially at the Oro Fino shaft inflow (at $\mathrm{C}$ in fig. 6A), but the greatest increase occurred downstream from $776 \mathrm{~m}$ (at D in fig. 6A), where the median instream colloidal concentration for stream group 3 was 235 $\mu \mathrm{g} / \mathrm{L}$, an increase from $47.7 \mu \mathrm{g} / \mathrm{L}$ for stream group 2 . The increase was in response to the iron-rich inflows at $831 \mathrm{~m}$ and $870 \mathrm{~m}$. Downstream from $896 \mathrm{~m}$, a steady decrease in the colloidal iron concentration occurred, suggesting that there were no more inflows with high iron concentrations.

Concentrations of dissolved and colloidal copper were greater than the method detection limits all along the study reach and were greater than concentrations of dissolved copper for part of the study reach (fig. 6B). Downstream from the Gilt Edge mine discharge, the median dissolved copper concentra- 

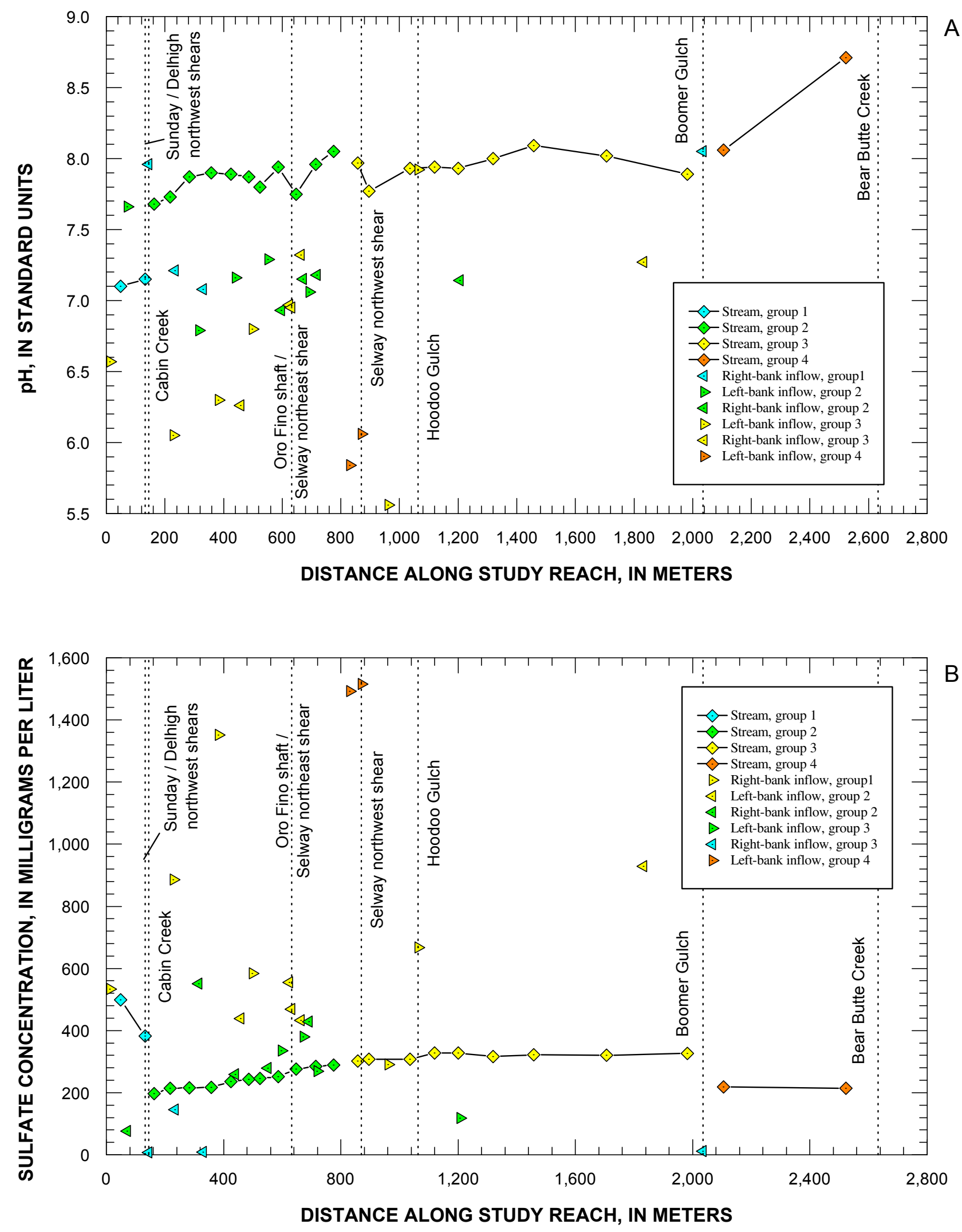

Figure 4. Variation of $(\mathrm{A}) \mathrm{pH}$ and (B) sulfate concentration with distance along the study reach, Strawberry Creek, South Dakota. 

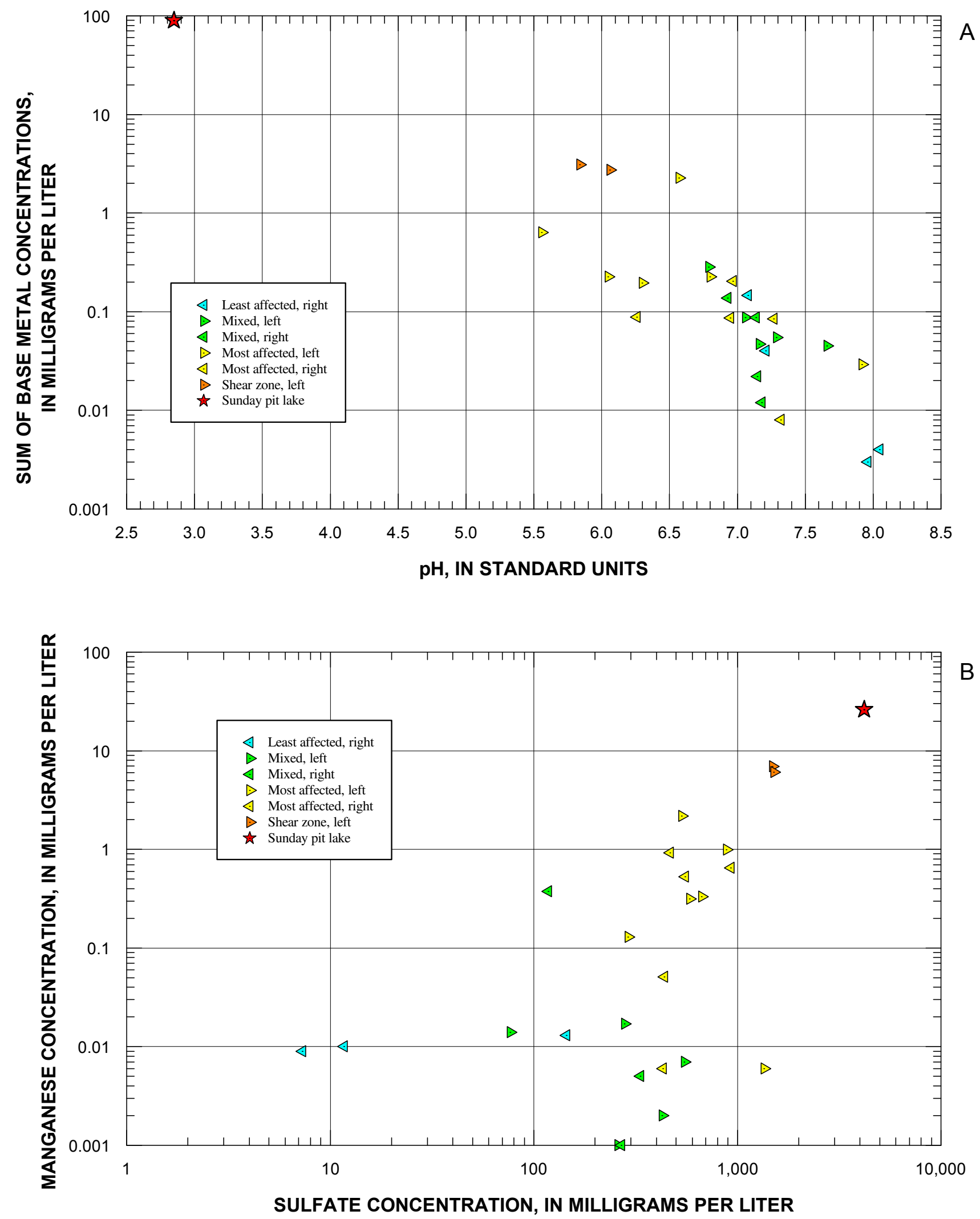

Figure 5. Variation of $(A)$ sum of base metal concentrations with $\mathrm{pH}$ and $(\mathrm{B})$ manganese concentration with sulfate concentration for inflow samples and for the Sunday pit lake, Strawberry Creek, South Dakota. 
Table 7. Median values of dissolved and colloidal concentrations for selected constituents for stream groups defined by cluster analysis [m, meters; mg/L milligrams per liter; $\mu \mathrm{g} / \mathrm{L}$, micrograms per liter; $<$ less than]

\begin{tabular}{|c|c|c|c|c|}
\hline \multirow[b]{2}{*}{ Constituent } & \multicolumn{4}{|c|}{ Stream group } \\
\hline & $\begin{array}{c}1 \\
\text { Discharge from } \\
\text { Gilt Edge mine to } \\
\text { Cabin Creek }\end{array}$ & $\begin{array}{c}2 \\
\text { Downstream } \\
\text { from Cabin } \\
\text { Creek to } 776 \mathrm{~m}\end{array}$ & $\begin{array}{c}3 \\
\text { Downstream from } \\
776 \mathrm{~m} \text { to Boomer } \\
\text { Gulch }\end{array}$ & $\begin{array}{c}4 \\
\text { Downstream from } \\
\text { Boomer Gulch }\end{array}$ \\
\hline Number of samples & 3 & 11 & 9 & 2 \\
\hline $\mathrm{pH}$, in standard units & 6.94 & 7.86 & 7.95 & 8.39 \\
\hline Calcium, dissolved, mg/L & 118 & 77.7 & 89.9 & 66.3 \\
\hline Magnesium, dissolved, mg/L & 35.5 & 18.1 & 20.5 & 14.9 \\
\hline Sodium, dissolved, mg/L & 20.5 & 20.6 & 35.5 & 27.3 \\
\hline Alkalinity as $\mathrm{CaCO}_{3}, \mathrm{mg} / \mathrm{L}$ & 23.2 & 68.8 & 73.3 & 88.3 \\
\hline Sulfate, dissolved, mg/L & 438 & 220 & 288 & 194 \\
\hline Sulfate, colloidal, mg/L & $<4.7$ & 4.92 & $<4.7$ & $<4.7$ \\
\hline Chloride, dissolved, $\mathrm{mg} / \mathrm{L}$ & 9.12 & 10.9 & 9.26 & 6.12 \\
\hline Silica as $\mathrm{SiO}_{2}$, dissolved, $\mathrm{mg} / \mathrm{L}$ & 24.4 & 17.3 & 16.0 & 14.6 \\
\hline Silica as $\mathrm{SiO}_{2}$, colloidal, $\mathrm{mg} / \mathrm{L}$ & 1.08 & .338 & $<0.156$ & $<0.156$ \\
\hline Aluminum, dissolved, $\mu \mathrm{g} / \mathrm{L}$ & 118 & 106 & 43.8 & 20.3 \\
\hline Aluminum, colloidal, $\mu \mathrm{g} / \mathrm{L}$ & 1,730 & 310 & 111 & 61.3 \\
\hline Arsenic, dissolved, $\mu \mathrm{g} / \mathrm{L}$ & .143 & .453 & .360 & .335 \\
\hline Arsenic, colloidal, $\mu \mathrm{g} / \mathrm{L}$ & .283 & .161 & .150 & .090 \\
\hline Barium, dissolved, $\mu \mathrm{g} / \mathrm{L}$ & 24.5 & 18.8 & 17.4 & 16.5 \\
\hline Barium, colloidal, $\mu \mathrm{g} / \mathrm{L}$ & .190 & 1.00 & .819 & 2.43 \\
\hline Cadmium, dissolved, $\mu \mathrm{g} / \mathrm{L}$ & 51.7 & 11.9 & 6.06 & 2.22 \\
\hline Cadmium, colloidal, $\mu \mathrm{g} / \mathrm{L}$ & .477 & .281 & .520 & .240 \\
\hline Chromium, dissolved, $\mu \mathrm{g} / \mathrm{L}$ & .080 & .086 & .072 & .055 \\
\hline Chromium, colloidal, $\mu \mathrm{g} / \mathrm{L}$ & .133 & .055 & .051 & .070 \\
\hline Cobalt, dissolved, $\mu \mathrm{g} / \mathrm{L}$ & 12.7 & 3.62 & 2.46 & .700 \\
\hline Cobalt, colloidal, $\mu \mathrm{g} / \mathrm{L}$ & .357 & .060 & .068 & .110 \\
\hline Copper, dissolved, $\mu \mathrm{g} / \mathrm{L}$ & 124 & 29.3 & 7.22 & 3.35 \\
\hline Copper, colloidal, $\mu \mathrm{g} / \mathrm{L}$ & 74.4 & 21.2 & 11.7 & 3.39 \\
\hline Iron, dissolved, $\mu \mathrm{g} / \mathrm{L}$ & $<24$ & $<24$ & $<24$ & $<24$ \\
\hline Iron, colloidal, $\mu \mathrm{g} / \mathrm{L}$ & 57.7 & 47.7 & 235 & 90.7 \\
\hline Lead, dissolved, $\mu \mathrm{g} / \mathrm{L}$ & $<0.3$ & $<0.3$ & $<0.3$ & $<0.3$ \\
\hline Lead, colloidal, $\mu \mathrm{g} / \mathrm{L}$ & .370 & $<0.3$ & $<0.3$ & .320 \\
\hline Manganese, dissolved, $\mu \mathrm{g} / \mathrm{L}$ & 1,820 & 444 & 267 & 78.5 \\
\hline Manganese, colloidal, $\mu \mathrm{g} / \mathrm{L}$ & 27.2 & 12.4 & 7.68 & $<5$ \\
\hline Molybdenum, dissolved, $\mu \mathrm{g} / \mathrm{L}$ & .843 & .735 & .702 & .605 \\
\hline Molybdenum, colloidal, $\mu \mathrm{g} / \mathrm{L}$ & $<0.25$ & $<0.25$ & $<0.25$ & $<0.25$ \\
\hline Nickel, dissolved, $\mu \mathrm{g} / \mathrm{L}$ & 75.8 & 17.9 & 12.7 & 5.02 \\
\hline Nickel, colloidal, $\mu \mathrm{g} / \mathrm{L}$ & 1.36 & $<0.13$ & .244 & .440 \\
\hline Strontium, dissolved, $\mu \mathrm{g} / \mathrm{L}$ & 612 & 350 & 384 & 294 \\
\hline Strontium, colloidal, $\mu \mathrm{g} / \mathrm{L}$ & .860 & 9.95 & 14.6 & 6.99 \\
\hline
\end{tabular}


Table 7. Median values of dissolved and colloidal concentrations for selected constituents for stream groups defined by cluster analysis-Continued

\begin{tabular}{lcccc}
\hline & \multicolumn{3}{c}{ Stream group } \\
\cline { 2 - 5 } \multicolumn{1}{c}{ Constituent } & $\mathbf{1}$ & $\mathbf{2}$ & $\mathbf{3}$ \\
& $\begin{array}{c}\text { Discharge from } \\
\text { Gilt Edge mine to } \\
\text { Cabin Creek }\end{array}$ & $\begin{array}{c}\text { Downstream } \\
\text { from Cabin } \\
\text { Creek to } \mathbf{7 7 6} \text { m }\end{array}$ & $\begin{array}{c}\text { Downstream from } \\
\text { 776 m to Boomer } \\
\text { Gulch }\end{array}$ & $\begin{array}{c}\text { Downstream from } \\
\text { Boomer Gulch }\end{array}$ \\
\hline Vanadium, dissolved, $\mu \mathrm{g} / \mathrm{L}$ & .143 & .200 & .094 & .098 \\
Vanadium, colloidal, $\mu \mathrm{g} / \mathrm{L}$ & .093 & $<0.06$ & 150 & .095 \\
Zinc, dissolved, $\mu \mathrm{g} / \mathrm{L}$ & 1,559 & 307 & 20.1 & 56.3 \\
Zinc, colloidal, $\mu \mathrm{g} / \mathrm{L}$ & 25.2 & 21.0 & $<3$ \\
\hline
\end{tabular}

tion was $124 \mu \mathrm{g} / \mathrm{L}$, and the colloidal concentration was 74.4 $\mu \mathrm{g} / \mathrm{L}$ (table 7 ). These concentrations were diluted by water from Cabin Creek to $29.3 \mu \mathrm{g} / \mathrm{L}$ for the dissolved concentration and $21.2 \mu \mathrm{g} / \mathrm{L}$ for the colloidal concentration for stream group 2. Both dissolved and colloidal concentrations continued to decrease downstream. At $776 \mathrm{~m}$, where stream group 3 began, dissolved and colloidal concentrations switched and the colloidal concentration was greater than the dissolved (table 7). This change most likely reflected the sorption or co-precipitation of dissolved copper to the colloidal iron that formed downstream from the iron-rich inflows at 831 and $870 \mathrm{~m}$. This process has been observed and modeled in other streams affected by mine drainage (Runkel and others, 1999).

Zinc concentration did not increase at $776 \mathrm{~m}$, even though concentrations of zinc in samples from 831 and $870 \mathrm{~m}$ were high (fig. 6C). Colloidal zinc concentrations were low compared to dissolved zinc concentrations (table 7). Upstream from about $400 \mathrm{~m}$, concentrations of both copper (fig. 6B) and zinc (fig. 6C) exceeded water-quality standards for the State of South Dakota (South Dakota Department of Environment and Natural Resources, 2004).

Most other trace metals followed this pattern of copper and zinc: with initially high concentrations from the Gilt Edge mine discharge, dilution by Cabin Creek, and general dilution most of the rest of the study reach (table 7). Colloidal aluminum concentrations were consistently higher than dissolved concentrations. Median colloidal lead concentrations were measurable upstream from Cabin Creek and downstream from Boomer Gulch, but both dissolved and colloidal concentrations were less than detection for the other stream groups. Dissolved concentrations of manganese and most other metals were greater than colloidal concentrations for each stream group. Colloidal concentrations were measurable, however, because of the low method detection limits that were possible with the ICP-MS measurement.

\section{Quantification of Mass Loading}

Changes in mass loading quantify instream changes of chemical character along the study reach. These changes result from physical, chemical, and biological processes. Loading quantities for individual stream segments are the basic data that point out the locations where loading occurs and indicate the relative importance of the different locations. Although the quantities of loading for the various constituents range from hundreds of $\mathrm{kg} /$ day to fractions of a $\mathrm{kg} /$ day, even the small quantities provide instructive patterns. The summary of cumulative instream and inflow loads at the end of table 8 is only for the segments of the study in Strawberry Creek, and the discussion of loading will focus on Strawberry Creek. Table 8 also contains the loading from Bear Butte Creek upstream from Strawberry Creek and at two locations downstream from Strawberry Creek (fig. 1; table 2). In general, the loading from Bear Butte Creek, upstream from Strawberry Creek, was greater for all the major constituents except for sodium and sulfate. Among trace constituents, the mining-related metals of cadmium, cobalt, copper, manganese, nickel, and zinc all had greater loads from Strawberry Creek than from Bear Butte Creek. For example, the aluminum load from Bear Butte Creek, upstream from Strawberry Creek, was $2.2 \mathrm{~kg} /$ day and from Strawberry Creek was $0.76 \mathrm{~kg} /$ day, but for copper the load from Bear Butte Creek was $0.013 \mathrm{~kg} /$ day while the load from Strawberry Creek was more than 6 times as much, at $0.085 \mathrm{~kg} /$ day. Thus, Strawberry Creek is a principal source of mine-related metals to Bear Butte Creek downstream from the confluence of the two.

Normalized profiles of loading are useful to indicate similarities or patterns of loading. For Strawberry Creek, normalized profiles indicate that there are three main patterns of mass loading among the constituents in this study (fig. 7). These profiles are normalized to the total cumulative instream load for each constituent, which is reported in table 8. A first group of constituents includes sulfate and other major constituents. These constituents followed a pattern characterized by multiple locations of loading along the study reach (fig. 7A). A second group of constituents includes most of the base metals (cadmium, copper, nickel, zinc), aluminum, and man- 
ganese. The group was characterized by a principal location of loading at the Gilt Edge mine discharge and a few, smaller downstream sources (fig. 7B). Iron loading differed from other metals because only one principal location of loading occurred between the Oro Fino shaft and Hoodoo Gulch (fig. 7C).

Looking in more detail at selected loading profiles will help to explain these patterns.

\section{Loading of Sulfate and Other Major Constituents}

Because the mineralogical sources of sulfate include ore, gangue, and bedrock minerals, the pattern of sulfate loading indicates aspects of weathering of all of these sources (fig. 8). In figure 8 and in subsequent plots of loading, the detailed loading profiles include the total or dissolved instream load with the colloidal instream load also included for most metals (from equation 4), the total cumulative instream load (sum of positive values of equation 5), and the cumulative inflow load (sum of values of equation 6). These profiles include calculations for each stream segment along the study reach, and the locations of important inflows are indicated by vertical lines on the graph. In figure $8 \mathrm{~B}$, the contribution of sampled inflow (equation 6), unsampled inflow (equation 7), and mass loss (negative values of equation 5) are summed for each of the stream segments.

Instream load of total sulfate increased in all but five stream segments, with the greatest individual increase from the discharge of the Gilt Edge mine at the beginning of the study reach (fig. 8B). Substantial increases also occurred downstream near the Oro Fino shaft (587 to $715 \mathrm{~m}$ ), Hoodoo Gulch (1,036 to $1,120 \mathrm{~m})$, and upstream from Boomer Gulch (1,706 to $1,982 \mathrm{~m}$, fig. 9C). Several stream segments from about 358 to $858 \mathrm{~m}$, both upstream and downstream from the Oro Fino shaft, contributed a substantial portion of the sulfate load (fig. 9B). This loading corresponds to several small seeps at stream level that were sampled along the stream in those segments, similar to the seeps shown in figure 9. These inflows had relatively high sulfate concentrations (fig. 4B) that could result from weathering of tailings material mixed with the alluvial deposits in the reach from Cabin Creek to Hoodoo Gulch (James Jonas, CDM Corp., oral commun., 2003). Other ore-related constituents, including aluminum, copper, manganese, nickel, and zinc, were added to the stream in segments between 358 and $858 \mathrm{~m}$, but these inputs were small compared to inputs of these constituents from the Gilt Edge mine $(12 \mathrm{~m}$, table 8).

Among the first group of constituents, loading of alkalinity (principally bicarbonate), barium, and silica principally occurred at Boomer Gulch (segment from 1,982 to 2,106 m), as illustrated by the loading profile of silica (fig. 10). These constituents are the products of weathering of the unaltered bedrock, which is indicated as undifferentiated Ordovician (fig. 1). This would primarily be the Winnipeg and Whitewood Formations that consist of sandstones and siltstones (Rocky Mountain Association of Geologists, 1972). Loadings of arse- nic, chromium, and vanadium; three metals that form anions, also occurred at Boomer Gulch (table 8). The amount of loading for these constituents was small compared to base-metal loading, but the low levels of detection limits enables quantification of their loading. Perhaps these constituents were more mobile because of the high alkalinity in Boomer Gulch - they may have had a source in the shale units up the Boomer Gulch drainage.

\section{Loading of Iron}

The loading pattern of iron (fig. 11) differed from that of the other constituents. The highest inflow concentrations of iron were in samples from the inflows at $831 \mathrm{~m}$ and $870 \mathrm{~m}$, and the greatest loading of iron was in the segments from 776 to $896 \mathrm{~m}$ (fig. 11B). Ferrous iron discharged to the stream rapidly oxidizes and forms colloidal iron in the stream (Kimball and others, 1994b). The rapid transformation occurs at a $\mathrm{pH}$ greater than 7.0 because of the fast rate of abiotic oxidation at higher $\mathrm{pH}$ (McKnight and others, 1988; McKnight and others, 2001; Singer and Stumm, 1970). Loading in segments from 776 to $896 \mathrm{~m}$ is dominated by iron, but there also was a small but measurable loading of cobalt, manganese, nickel, and zinc (table 8). Loading of these metals could have been greater than measured if sorption reactions with iron precipitates on the streambed removed them to the streambed rapidly (Nordstrom and Alpers, 1999; Smith, 1999). Downstream from these ironrich inflows, the colloidal iron load consistently decreased, indicating that the decrease in iron concentration (fig. 11A) was a result of removal from the water column to the stream bed, and not a result of dilution (Kimball and others, 1994a).

The unique pattern of iron loading could, in part, be a result of the reactive nature of iron at the relatively high $\mathrm{pH}$ of Strawberry Creek. The rate of the iron oxidation and precipitation reactions within the water column is on the order of seconds (Broshears and others, 1996; Grundl and Delwiche, 1993; Kimball and others, 1994b). Iron could have been added within a stream segment, but could have reacted and been removed from the water column all within the distance between stream-sampling sites. Thus, iron load is more likely to remain relatively low unless there is an overwhelming inflow like those in segments between 776 to $896 \mathrm{~m}$. Even within stream segments, the inflow load (green line, fig. 11A) was much greater than the cumulative instream load (red line, fig. 11A), which can be an indication that most of the iron that came into the stream was removed through these chemical reactions.

\section{Loading of Mine-Related Metals}

Loading from the Gilt Edge mine, accounted for by loads at $12 \mathrm{~m}$, was the greatest source of loading for aluminum, cadmium, copper, manganese, nickel, strontium, and zinc (table 8; fig. 7B). This loading is illustrated by the profiles of copper (fig. 12) and zinc (fig. 13). Downstream from this principal 

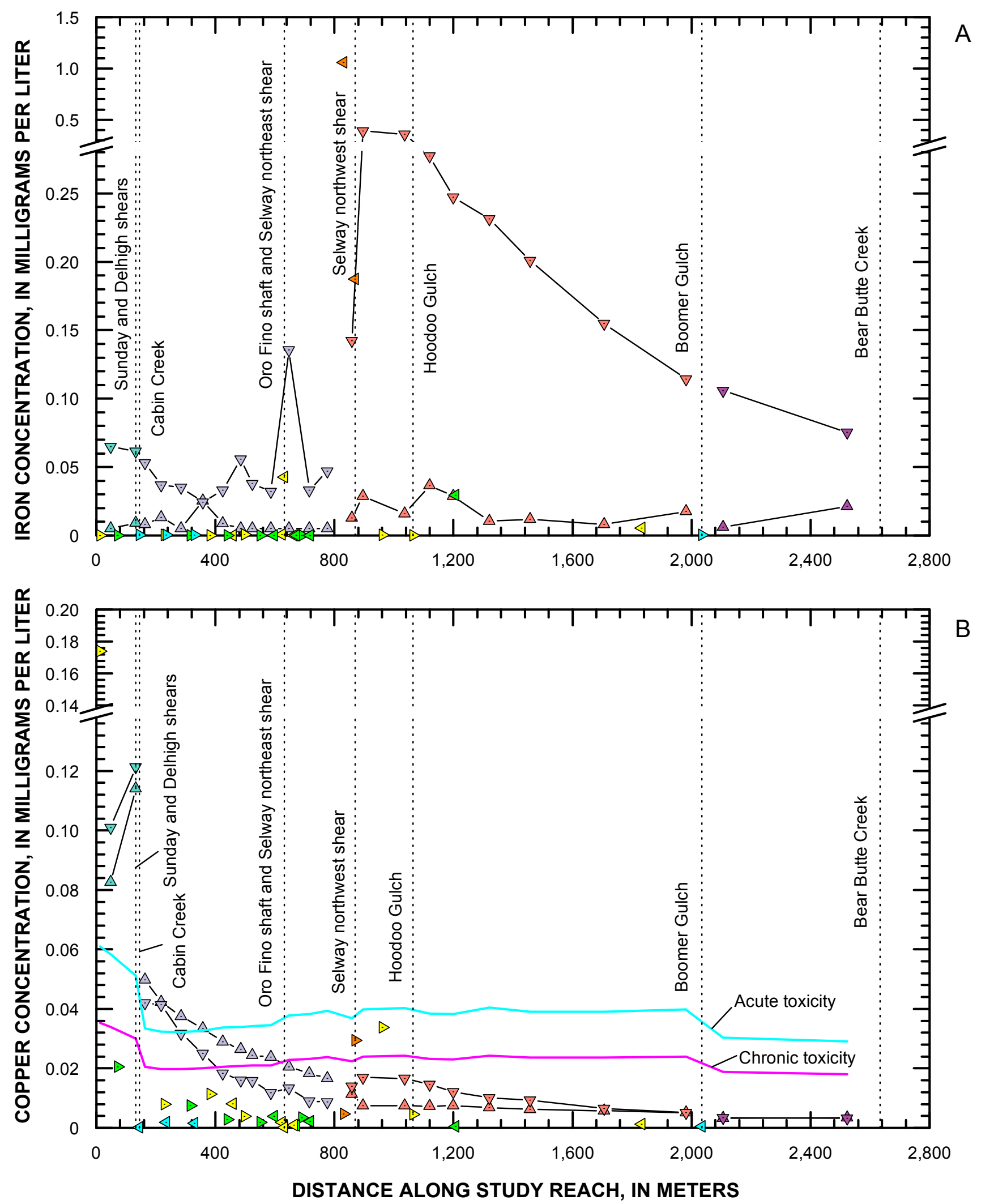

Figure 6. Variation of dissolved and colloidal (A) iron, $(B)$ copper, and $(C)$ zinc concentrations with distance along the study reach, Strawberry Creek, South Dakota. 


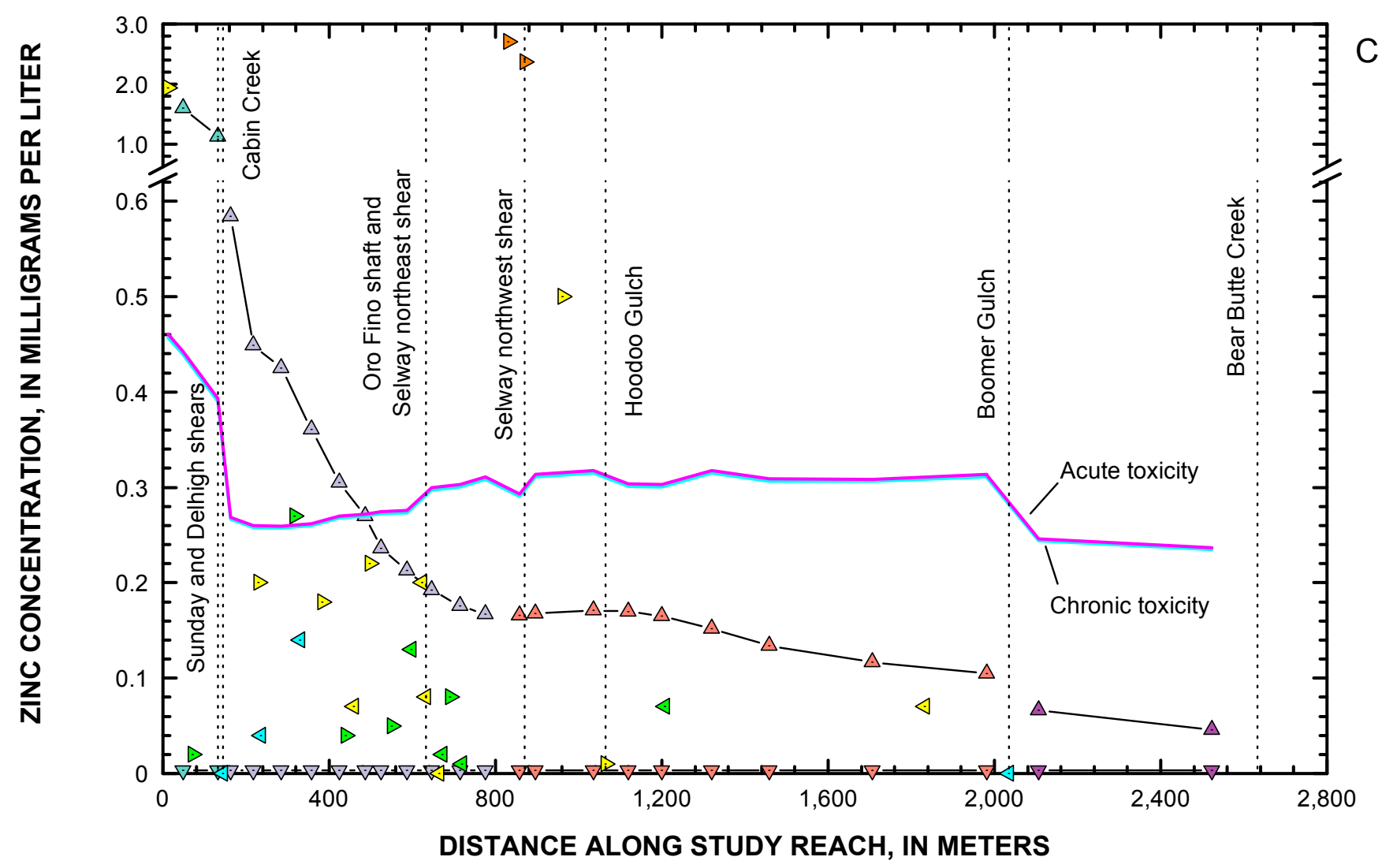

EXPLANATION

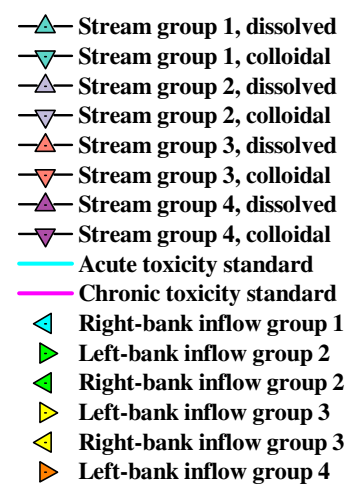

Figure 6. Variation of dissolved and colloidal (A) iron, $(B)$ copper, and (C) zinc concentrations with distance along the study reach, Strawberry Creek, South Dakota-Continued. 
Table 8. Mass loading for individual stream segments and summary of loading for Strawberry Creek, South Dakota

[All loads in kilograms per day; distance, in meters at the end of stream segment; color of cells indicates the rank of the loading: red. greatest load; orange, second greatest; yellow, third greatest; green, fourth greatest; blue, fifth greatest; blank entries indicate that the loading was less than load error]

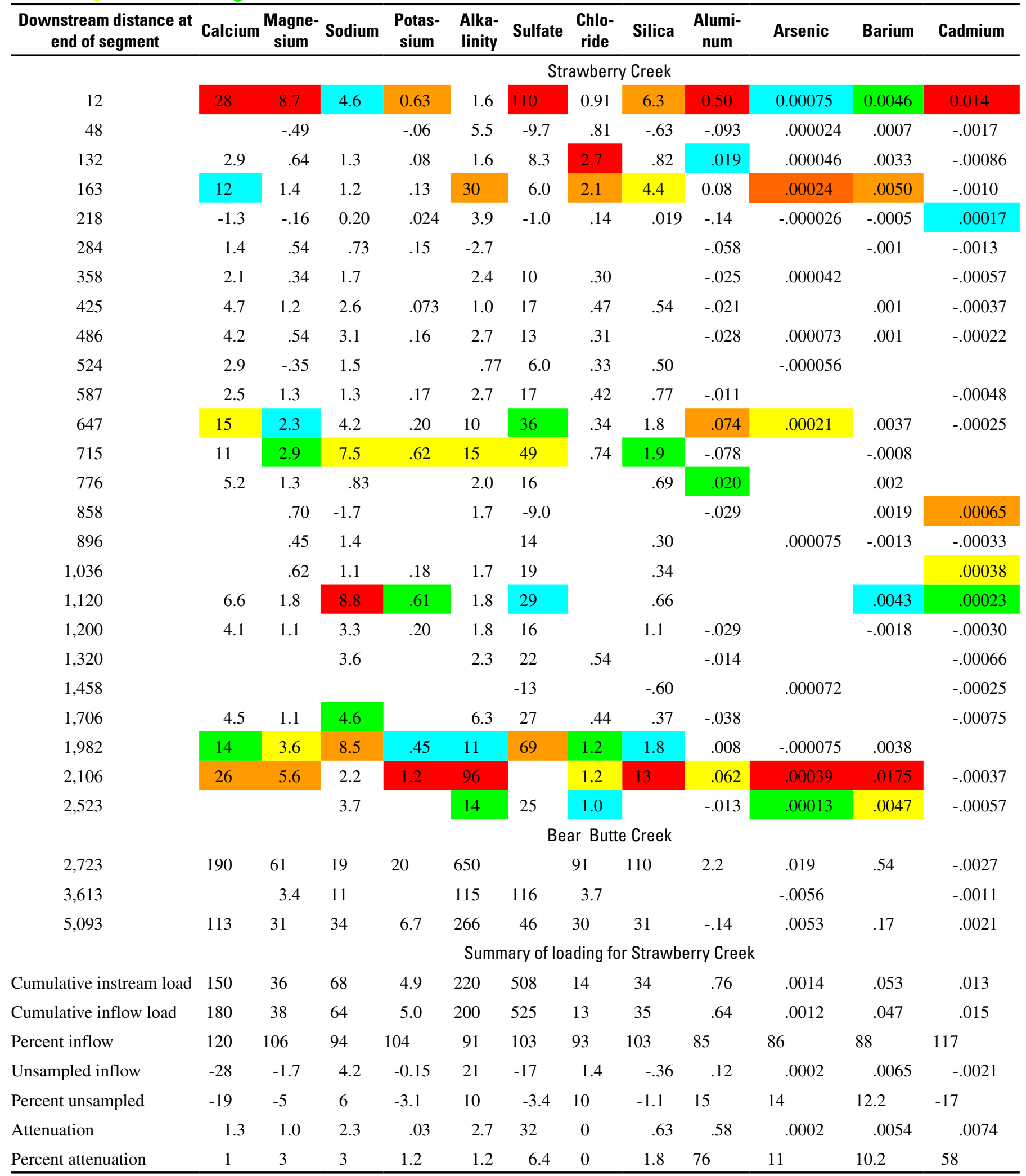


Table 8. Mass loading for individual stream segments and summary of loading for Strawberry Creek, South Dakota—Continued

\begin{tabular}{|c|c|c|c|c|c|c|c|c|c|c|}
\hline Chromium & Cobalt & Copper & Iron & Lead & Manganese & Molybdenum & Nickel & Strontium & Vanadium & Zinc \\
\hline \multicolumn{11}{|c|}{ Strawberry Creek } \\
\hline 0.000044 & 0.0032 & 0.056 & 0.011 & 0.000075 & 0.49 & 0.00015 & 0.020 & 0.15 & 0.000048 & 0.44 \\
\hline .000005 & -.00043 & -.0154 & .004 & .000018 & -.049 & .000063 & -.0022 & & .000004 & -.067 \\
\hline .000014 & .00065 & .026 & .005 & .000085 & -.046 & .000056 & -.0014 & .017 & .000019 & -.039 \\
\hline .00003 & -.00045 & -.0133 & .016 & .000090 & .0075 & .00018 & -.0020 & .063 & .00010 & \\
\hline .0000051 & .00037 & -.0043 & -.006 & -.000071 & -.038 & -.000022 & .0011 & -.008 & -.000013 & -.049 \\
\hline-.0000029 & -.00059 & -.0073 & -.005 & -.000039 & -.021 & & -.0024 & & & -.030 \\
\hline-.0000089 & -.00010 & -.0052 & .007 & & -.009 & & & & & -.030 \\
\hline-.0000023 & -.00016 & -.0053 & -.003 & & -.018 & .000073 & & .025 & & -.020 \\
\hline .0000093 & & -.0017 & .013 & .000045 & -.013 & & & & .000016 & -.018 \\
\hline-.000015 & .00008 & & -.010 & -.000057 & & & & .020 & & .046 \\
\hline .000017 & \multirow[t]{2}{*}{-.0004} & -.0022 & -.004 & & -.010 & .000084 & -.0012 & & -.000012 & -.064 \\
\hline .000065 & & .0018 & .092 & \multirow[t]{2}{*}{.000042} & & & & .096 & .000028 & \\
\hline-.000042 & -.000098 & -.0023 & -.084 & & -.013 & .00015 & & & & \\
\hline-.000042 & -.000042 & \multirow[t]{5}{*}{-.0011} & .014 & \multirow[t]{7}{*}{.000043} & & \multirow[t]{4}{*}{-.00011} & & \multirow{4}{*}{.045} & .000018 & .014 \\
\hline .000023 & .00078 & & .111 & & .029 & & .0038 & & .000026 & \\
\hline-.000028 & .00035 & & .272 & & .055 & & -.0011 & & -.000044 & .025 \\
\hline .000015 & .00029 & & -.035 & & & & .0018 & & & \\
\hline .000027 & .00017 & & -.044 & & -.015 & .00013 & .0013 & .069 & .000023 & -.012 \\
\hline .0000094 & -.00038 & -.0018 & -.032 & & -.008 & & & & & \\
\hline-.00002 & -.00040 & -.0029 & -.036 & & & & -.0019 & & -.000040 & \\
\hline .000047 & -.00014 & & -.021 & .00015 & -.038 & .00015 & -.0007 & & .000047 & -.020 \\
\hline-.000042 & -.00052 & -.0036 & -.054 & -.00014 & -.050 & & -.0014 & .030 & -.000041 & -.018 \\
\hline .000023 & \multirow[t]{2}{*}{-.00010} & -.0009 & -.022 & .000055 & \multirow[t]{2}{*}{-.031} & .00014 & & .047 & & \multirow[t]{2}{*}{-.008} \\
\hline .000095 & & .0007 & .067 & .00017 & & .00034 & & .097 & .00028 & \\
\hline .000087 & -.00033 & & -.021 & .00077 & -.063 & & -.0009 & .12 & .000090 & -.028 \\
\hline \multicolumn{11}{|c|}{ Bear Butte Creek } \\
\hline .0035 & .0021 & .013 & 6.56 & .0045 & .23 & .0018 & .0099 & .79 & .0063 & -.033 \\
\hline-.0011 & -.0006 & & -1.5 & -.0019 & .017 & & & & -.0017 & .013 \\
\hline .0012 & .0009 & .011 & .65 & .0014 & & .0018 & .0056 & .57 & .0011 & .041 \\
\hline \multicolumn{11}{|c|}{ Summary of loading for Strawberry Creek } \\
\hline .00051 & .0029 & .085 & .611 & .0015 & .58 & .0015 & .028 & .78 & .00070 & .52 \\
\hline .00024 & .0094 & .062 & 1.83 & .0004 & .90 & .0011 & .037 & .71 & .00055 & .58 \\
\hline 47 & 326 & 73 & 299 & 28 & 155 & 69 & 131 & 91 & 78 & 112 \\
\hline .00027 & -.0065 & .023 & -1.22 & .0011 & -.32 & .00047 & -.0089 & .071 & .00016 & -.06 \\
\hline 53 & -226 & 27 & -199 & 72 & -55 & 31 & -31 & 9.0 & 22 & -12 \\
\hline .00016 & .0011 & .067 & .356 & .00031 & .42 & .00013 & .015 & .008 & .00015 & .40 \\
\hline 32 & 38 & 80 & 58 & 20 & 73 & 9 & 54 & 1.0 & 21 & 78 \\
\hline
\end{tabular}



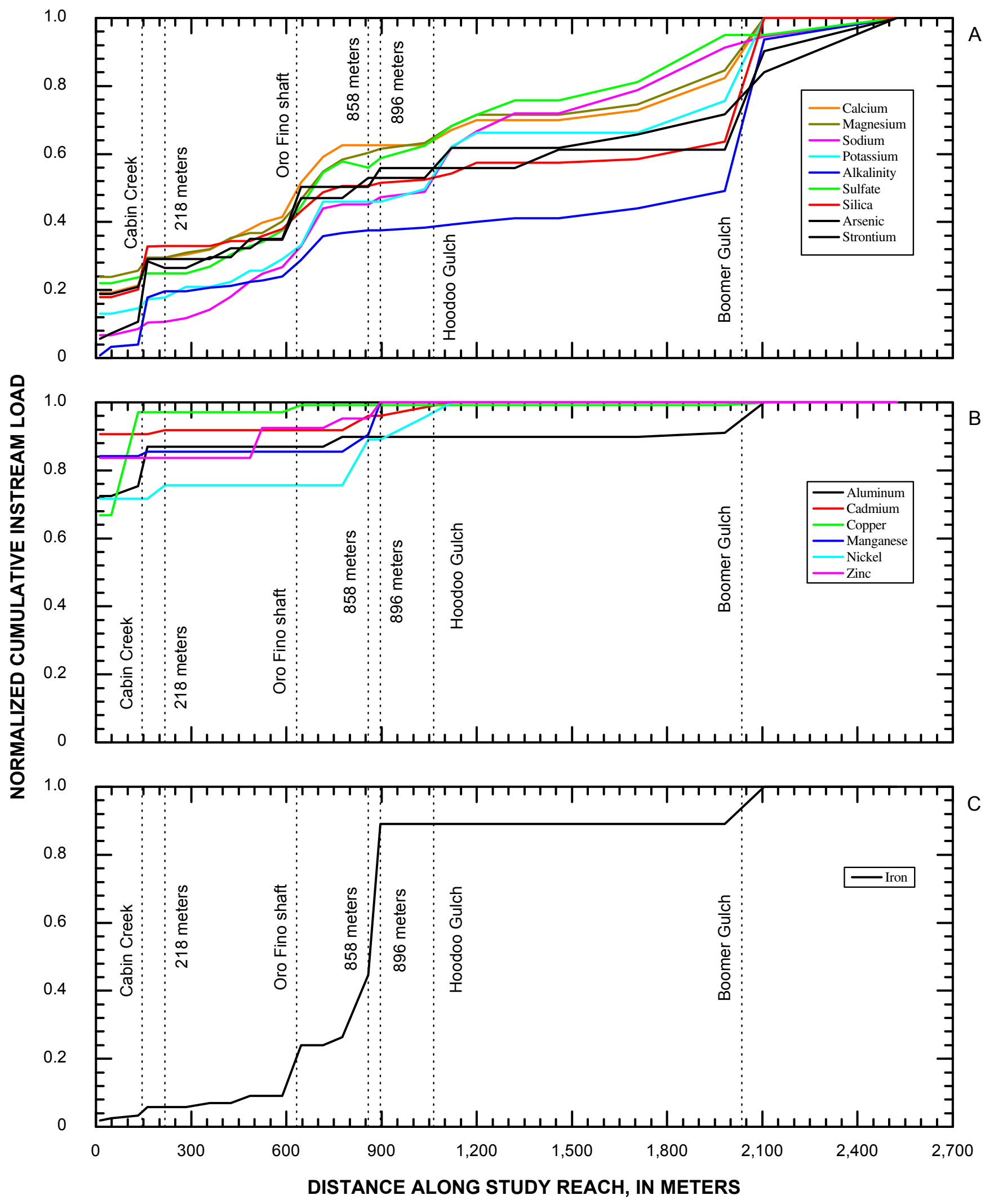

Figure 7. Normalized cumulative instream load for total (A) calcium, magnesium, sodium, potassium, alkalinity, sulfate, silica, arsenic, strontium; (B) aluminum, cadmium, copper, manganese, nickel, zinc; and (C) iron. 
location of loading, both these metals were progressively lost from the water column along the first $600 \mathrm{~m}$ of the study reach (fig. 12B and fig. 13B). An exception was some copper loading in the segment from 48 to $132 \mathrm{~m}$, but the source of this loading was uncertain. If the source of this second copper loading was related to the Gilt Edge mine, other metal loads besides copper should have increased, but copper was the only metal that had a measurable loading in that segment (table 8). Samples from inflows at 830 and $871 \mathrm{~m}$ that had high concentrations of copper (fig. 6B) and zinc (fig. 6C) occurred downstream from the reach where copper and zinc loads decreased. Despite the high inflow concentrations, no measurable loading of copper (fig. 12B) and only a small loading of zinc (fig. 13B) occurred in the segment from 858 to $896 \mathrm{~m}$. Perhaps increases in loads of copper and zinc in segments from 776 to $896 \mathrm{~m}$ were masked by a net loss from the stream. One indication of this possibility would be the substantial change in the partitioning of copper load from the dissolved to colloidal phase (fig. 12A), and by the increase in colloidal zinc load (fig. 13A). Both these results were likely tied to sorption reactions with the iron colloids, which were substantially removed from the water column downstream from $900 \mathrm{~m}$ (fig. 11A).

\section{Summary and Conclusions}

A mass-loading study addressed the possible hydrologic connection of pit lakes at the Gilt Edge mine in the Black Hills of South Dakota to Strawberry Creek, which discharges from the mine area. The connection could occur through shear zones that underlie the pit lakes and the stream. Numerous inflows occurred along the 2,523 m study reach of Strawberry Creek, mostly as small seeps near the stream. Classification of inflow and stream samples by cluster analysis indicated distinct chemical differences among the inflow samples and also the locations where the chemical composition of the stream substantially changed. One of the inflow groups included samples draining from areas unaffected by any mining. Two other inflow groups included samples affected by interaction with mine wastes to varying degrees, and a fourth group included two inflow samples most affected by mining that occurred near the Selway northwest shear zone. These two inflows had the highest concentrations of metals among all the inflow samples. The location of these particular samples and their distinct chemical composition are consistent with the possible connection to the pit lake. Instream metal loads of copper and zinc downstream from the two inflows indicate an increase in colloidal transport of these metals, most likely associated with sorption of the metals to iron colloids, but the overall impact on copper and zinc loading to the stream is minimal. 

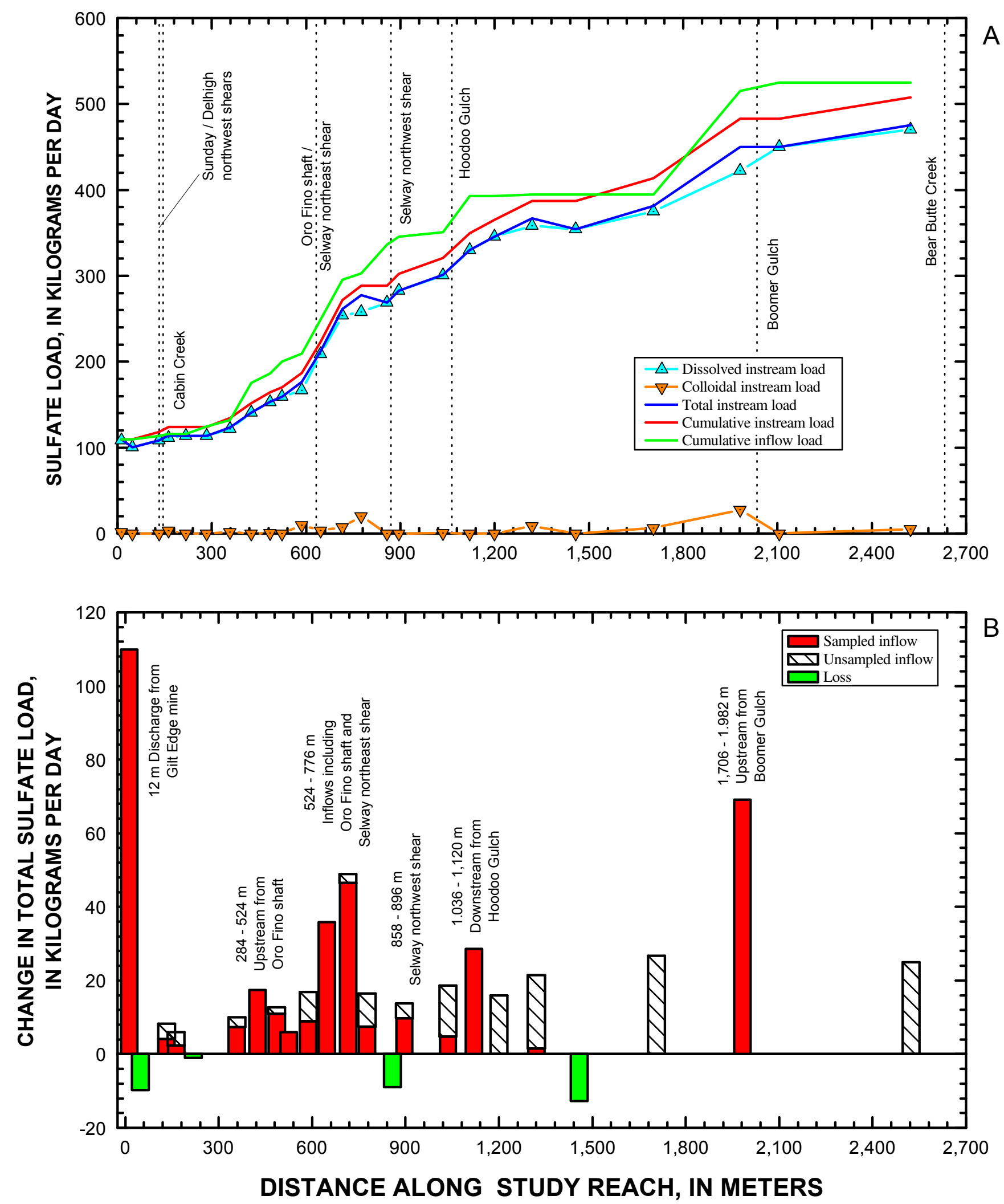

Figure 8. Variation of (A) sulfate load with distance along the study reach and (B) change in total sulfate load for individual segments along Strawberry Creek, South Dakota. 


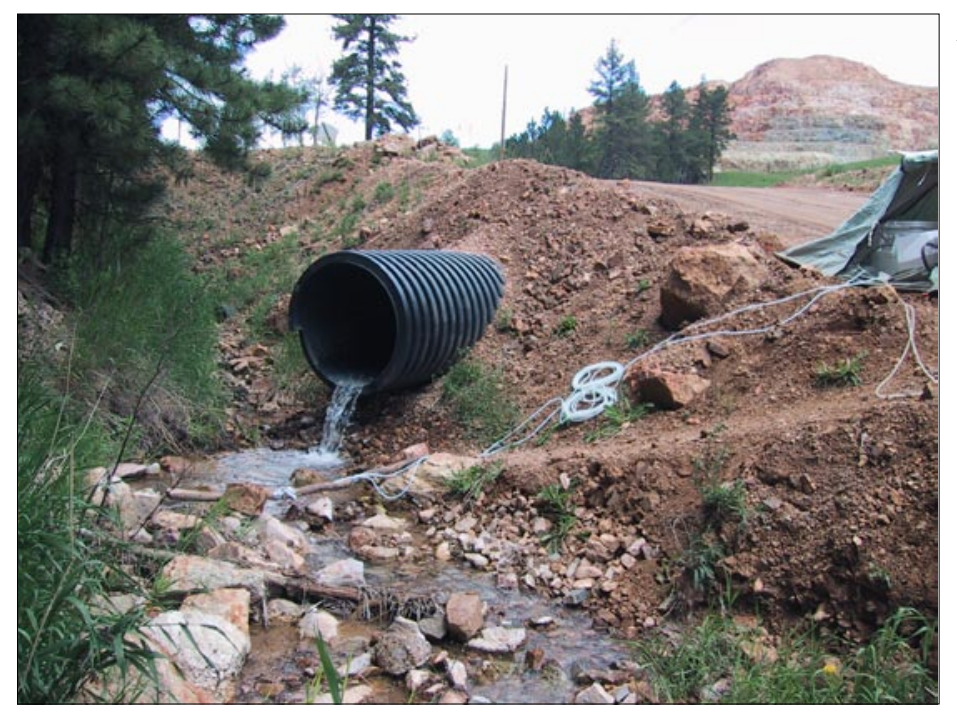

\section{A}

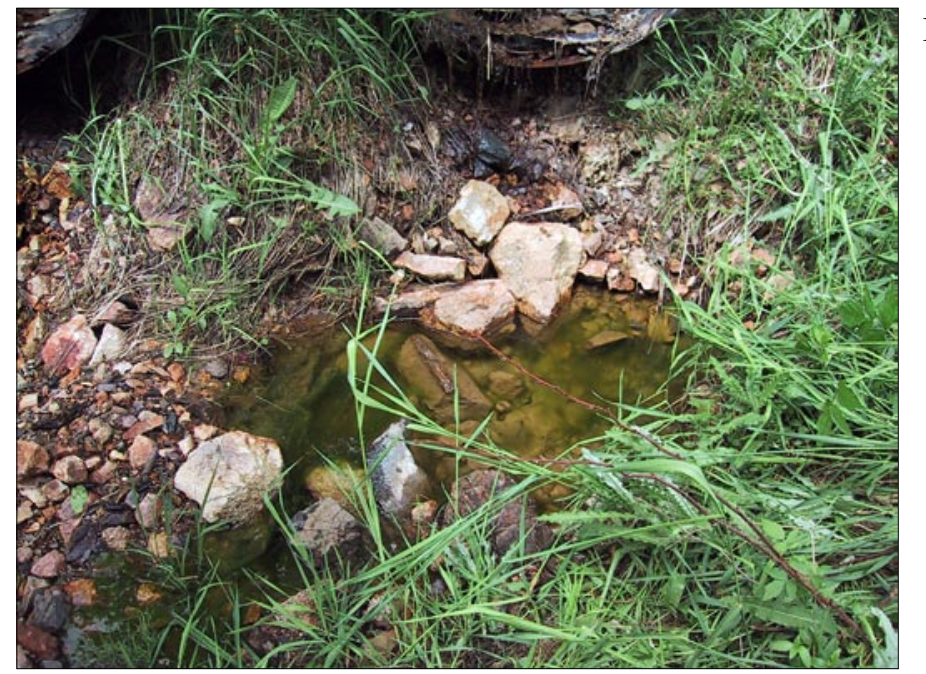

B

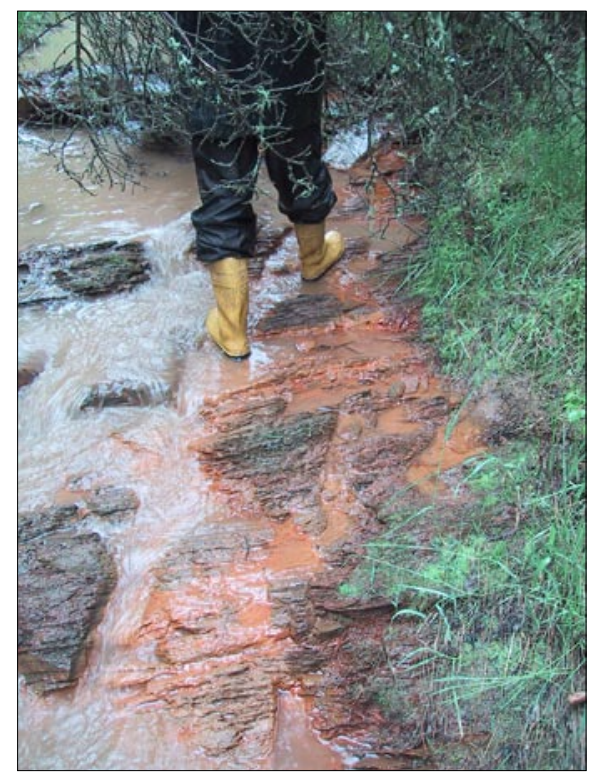

C

Figure 9. (A) Gilt Edge mine discharge, (B) seeps typical of those from 358 to 858 meters, and (C) iron-rich seeps from 1,708 to 1,982 meters. 

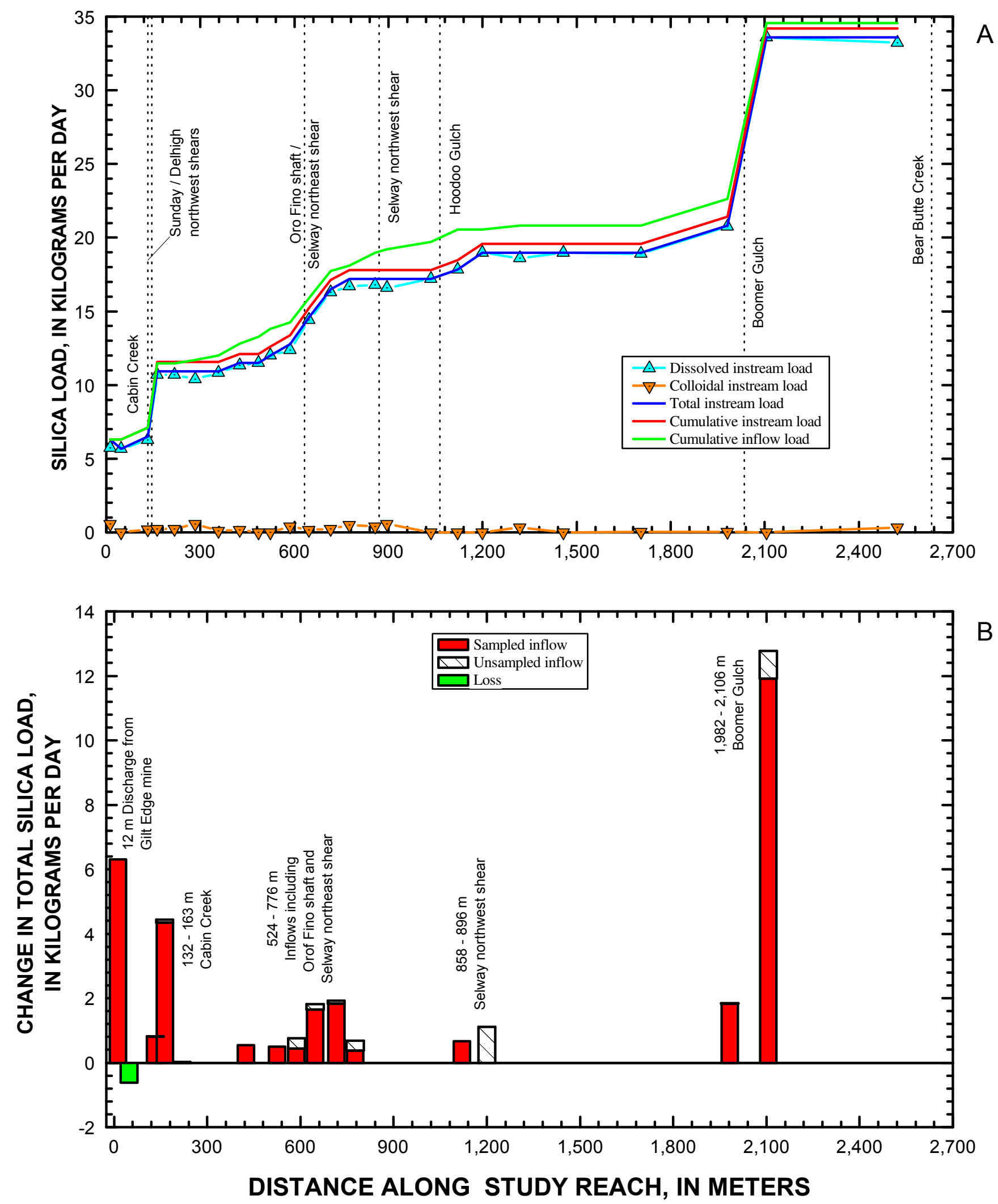

Figure 10. Variation of (A) total silica load with distance along the study reach and (B) change in total silica load for individual catchments along Strawberry Creek, South Dakota. 

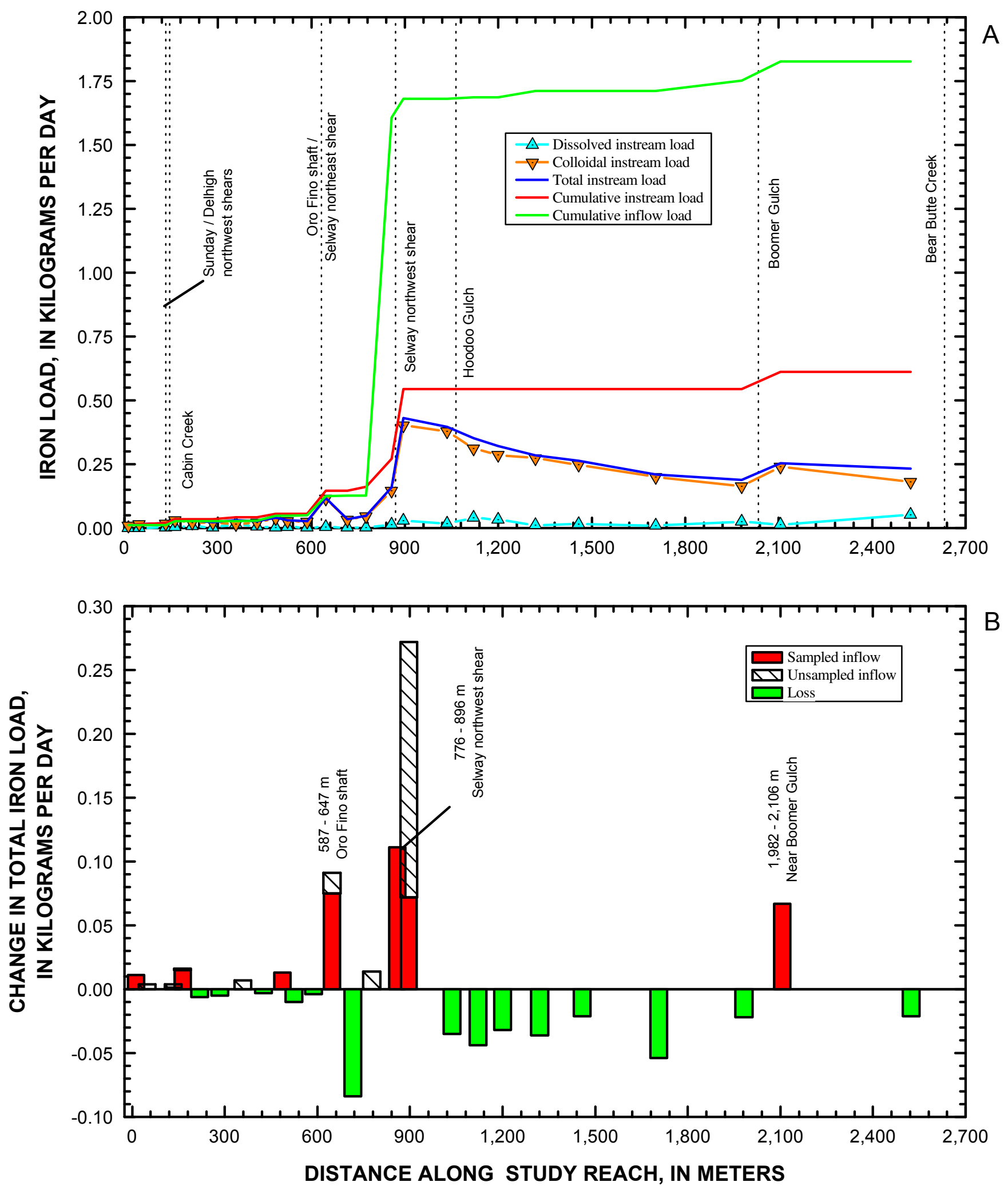

Figure 11. Variation of $(A)$ iron load with distance along the study reach and $(B)$ change in iron load for individual catchments along Strawberry Creek, South Dakota. 

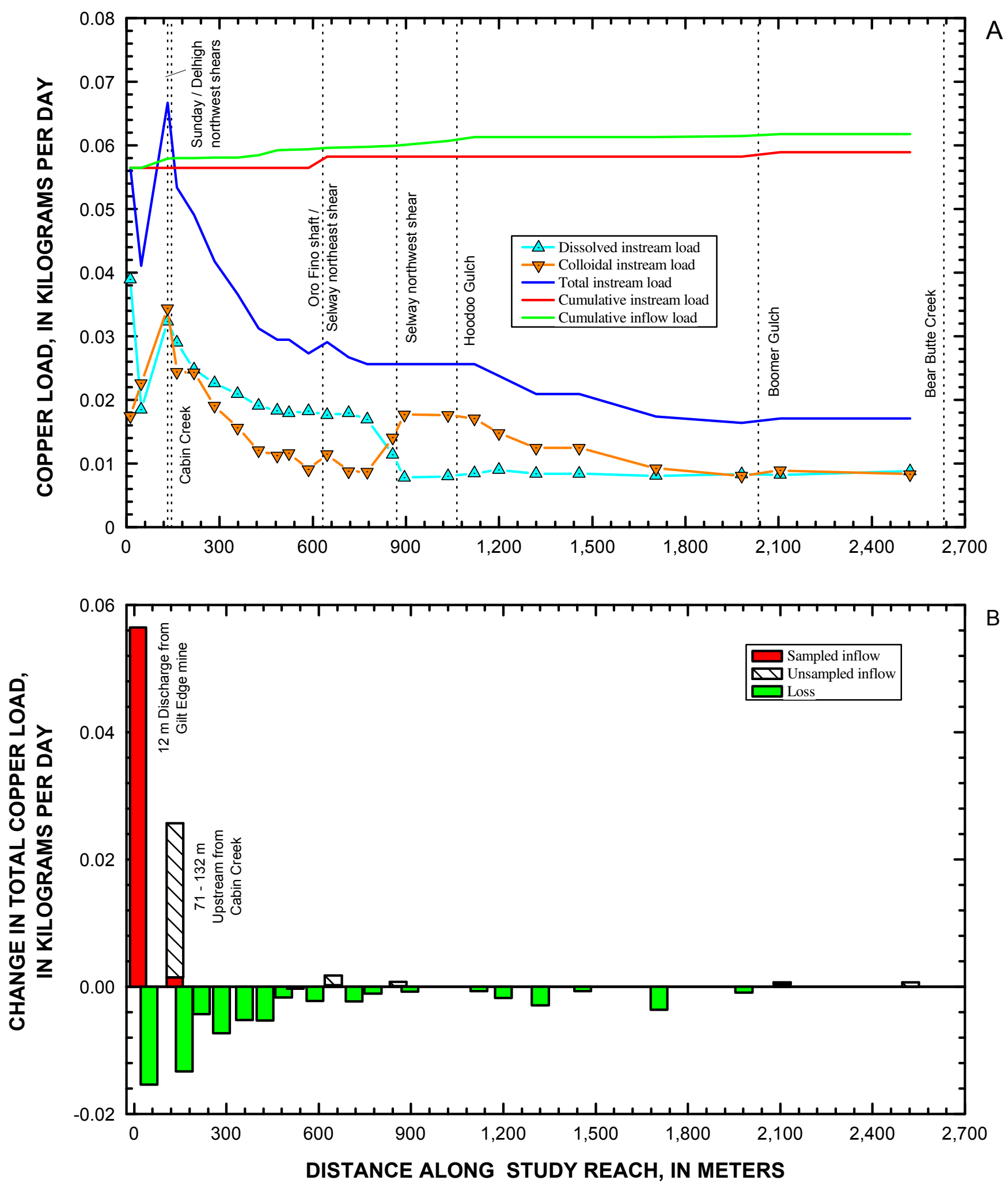

Figure 12. Variation of $(A)$ copper load with distance along the study reach and (B) change in copper load for individual catchments along Strawberry Creek, South Dakota. 

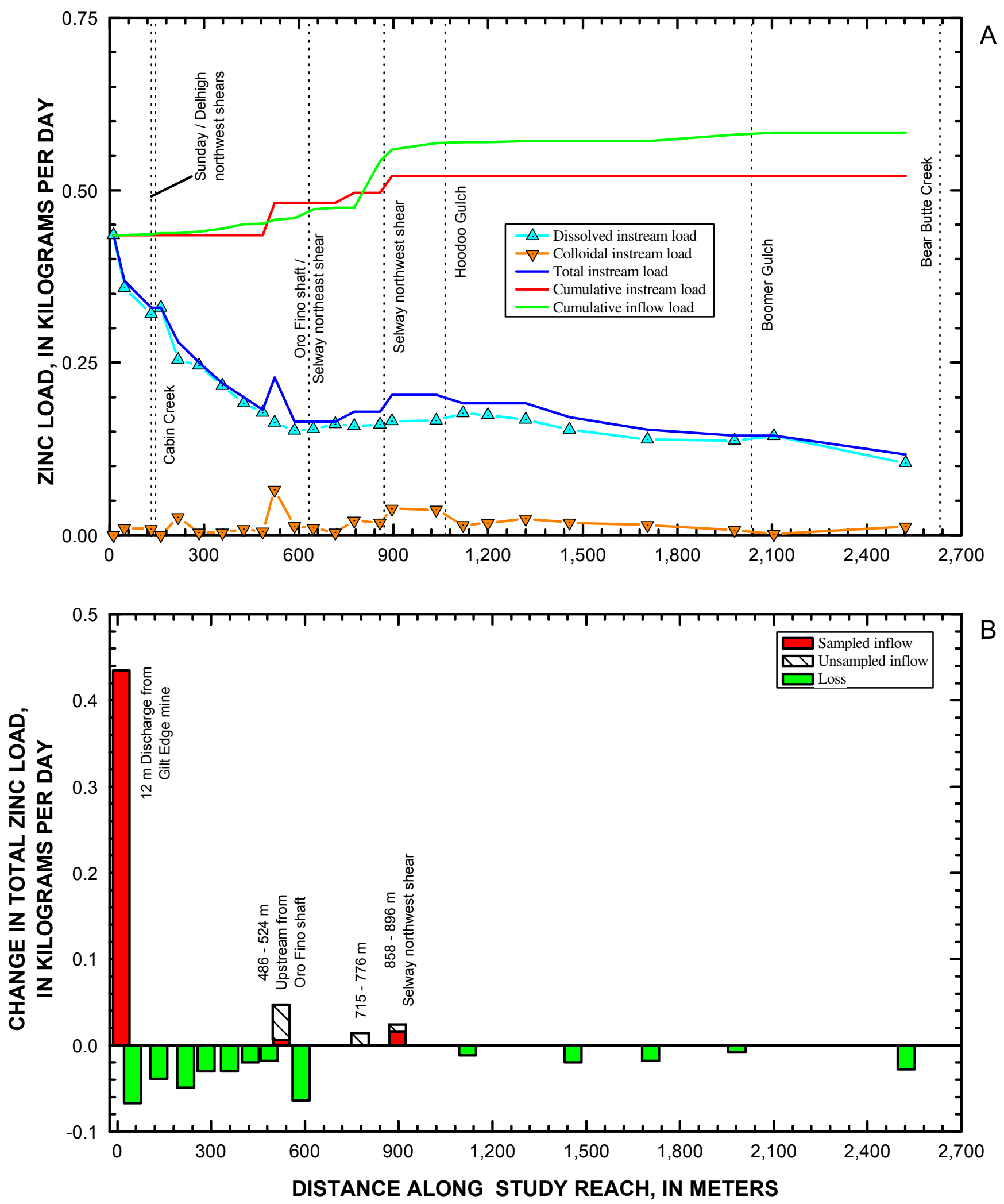

Figure 13. Variation of (A) zinc load with distance along the study reach and (B) change in zinc load for individual catchments along Strawberry Creek, South Dakota. 


\section{References Cited}

Barringer, J.L., and Johnsson, P.A., 1989, Theoretical considerations and a simple method for measuring alkalinity and acidity in low-pH waters by gran titration: U.S. Geological Survey Water-Resources Investigations Report 89-4029, 35 p.

Bencala, K.E., and McKnight, D.M., 1987, Identifying instream variability: Sampling iron in an acidic stream., in Averett, R.C. and McKnight, D.M., eds., Chemical Quality of Water and the Hydrologic Cycle: Chelsea, Michigan, Lewis Publishers, Inc., p. 255-269.

Bencala, K.E., McKnight, D.M., and Zellweger, G.W., 1990, Characterization of transport in an acidic and metal-rich mountain stream based on a lithium tracer injection and simulations of transient storage: Water Resources Research, v. 26, p. $989-1000$.

Bencala, K.E. and Ortiz, R.F., 1999, Theory and(or) reality: Analysis of sulfate mass-balance at Summitville, Colorado, poses process questions about the estimation of metal loadings, in Morganwalp, D.W. and Buxton, H.T., eds., U.S. Geological Survey Toxic Substances Hydrology Program-Proceedings of the technical meeting, Charleston, South Carolina, March 8-12, 1999--Volume 1 of 3--Contamination from hardrock mining: U.S. Geological Survey WaterResources Investigations Report 99-4018A. U.S. Geological Survey, p. 119-122.

Benoit, G., and Rozan, T.F., 1999, The influence of size distribution on the particle concentration effect and trace metal partitioning in rivers: Geochimica et Cosmochimica Acta, v. 63 , no. 1 , p. 113-127.

Brinton, T.I., Antweiler, R.C., and Taylor, H.E., 1996, Method for the determination of dissolved chloride, nitrate, and sulfate in natural water using ion chromatography: U.S. Geological Survey Open-File Report 95-426A, 16 p.

Broshears, R.E., Bencala, K.E., Kimball, B.A., and McKnight, D.M., 1993, Tracer-dilution experiments and solute-transport simulations for a mountain stream, Saint Kevin Gulch, Colorado: U.S. Geological Survey Water-Resources Investigations Report 92-4081, 18 p.

Broshears, R.E., Runkel, R.L., Kimball, B.A., Bencala, K.E., and McKnight, D.M., 1996, Reactive solute transport in an acidic stream: Experimental $\mathrm{pH}$ increase and simulation of controls on $\mathrm{pH}$, aluminum, and iron: Environmental Science \& Technology, v. 30, no. 10, p. 3016-3024.

Buffle, J., and Leppard, G.G., 1995, Characterization of aquatic colloids and macromolecules. 1. Structure and behavior of colloidal material: Environmental Science \& Technology, v. 29, no. 9, p. 2169-2175.
Church, S.E., Kimball, B.A., Fey, D.L., Ferderer, D.A., Yager, T.J., and Vaughn, R.B., 1997, Source, transport, and partitioning of metals between water, colloids, and bed sediments of the Animas River, Colorado: Denver, Colorado, U.S. Geological Survey Open-File Report 97-151, 135 p.

Davis, J.C., 2002, Statistics and data analysis in geology, $3^{\text {rd }}$ edition: New York, John Wiley \& Sons, Inc., 638 p.

Ficklin, W.H., Plumlee, G.S., Smith, K.S., and McHugh, J., 1992, Geochemical classification of mine drainages and natural drainages in mineralized areas, in Kharaka, Y.K. and Maest, A.S., eds., Water-rock interaction: Low temperature environments: Rotterdam, Netherlands, A.A. Balkema, p. 381-384.

Flury, M., and Papritz, A., 1993, Bromide in the natural environment: Occurrence and toxicity: Journal of Environmental Quality, v. 22, no. 4, p. 747-758.

Grundl, T., and Delwiche, J., 1993, Kinetics of ferric oxyhydroxide precipitation: Journal of Contaminant Hydrology, v. 14, p. 71-97.

Hoffman, M.R., Yost, E.C., Eisenreich, S.J., and Maier, W.J., 1981, Characterization of soluble and colloidal-phase metal complexes in river water by ultrafiltration: A mass-balance approach: Environmental Science \& Technology, v. 15, p. 655-661.

Jarrett, R.D., 1992, Hydraulics of mountain rivers, in Yen, B.C., ed., Channel flow resistance centennial of Manning's and Kuichling's rational formula: Littleton, Colorado, Water Resources Publications, p. 287-298.

Kaufman, L. and Rousseeuw, P.J., 1990, Finding groups in data: An introduction to cluster analysis: New York, Wiley, $368 \mathrm{p}$.

Kilpatrick, F.A., and Cobb, E.D., 1985, Measurement of discharge using tracers: U.S. Geological Survey Techniques of Water-Resources Investigations book 3, chap. A16, 27 p.

Kimball, B.A., Bencala, K.E., and Broshears, R.E., 1994a, Geochemical processes in the context of hydrologic transport: Reactions of metals in St. Kevin Gulch, Colorado, in Dutton, A., ed., Toxic Substances in the Hydrologic Sciences: Minneapolis, Minn., American Institute of Hydrology, p. 80-94.

Kimball, B.A., Broshears, R.E., Bencala, K.E., and McKnight, D.M., 1994b, Coupling of hydrologic transport and chemical reactions in a stream affected by acid mine drainage: Environmental Science \& Technology, v. 28, p. 2065-2073.

Kimball, B.A., Callender, E., and Axtmann, E.V., 1995, Effects of colloids on metal transport in a river receiving acid mine drainage, upper Arkansas River, Colorado, U.S.A.: Applied Geochemistry, v. 10, p. 285-306. 
Kimball, B.A., Nimick, D.A., Gerner, L.J., and Runkel, R.L., 1999, Quantification of metal loading in Fisher Creek by tracer injection and synoptic sampling, Park County, Montana, August 1997: U.S. Geological Survey WaterResources Investigations Report 99-4119, 40 p.

Kimball, B.A., Runkel, R.L., and Walton-Day, Katherine, 2003, Use of field-scale experiments and reactive solutetransport modelling to evaluate remediation alternatives in streams affected by acid mine drainage, in Jambor, J.L., Blowes, D.W., and Ritchie, A.I.M., eds., Environmental aspects of mine wastes: Vancouver, British Columbia, Mineralogical Association of Canada, p. 261-282.

Kimball, B.A., Runkel, R.L., Walton-Day, Katherine, and Bencala, K.E., 2002, Assessment of metal loads in watersheds affected by acid mine drainage by using tracer injection and synoptic sampling: Cement Creek, Colorado, USA: Applied Geochemistry, v. 17, no. 9, p. 1183-1207.

Lichte, F.E., Golightly, D.W., and Lamothe, P.J., 1987, Inductively coupled plasma-atomic emission spectrometry: U.S. Geological Survey Bulletin 1770, 10 p.

McKinnon, T.E., 2002, Sources and seasonal variability of metal and arsenic concentrations in the surface water of the Clark Fork River Basin, Montana: University of Montana, unpublished master's thesis, $115 \mathrm{p}$.

McKnight, D.M., Kimball, B.A., and Bencala, K.E., 1988, Iron photoreduction and oxidation in an acidic mountain stream.: Science, v. 240, p. 637-640.

McKnight, D.M., Kimball, B.A., and Runkel, R.L., 2001, pH dependence of iron photoreduction in a Rocky Mountain stream affected by acid mine drainage: Hydrological Processes, v. 15, no. 10, p. 1979-1992.

Morel, F.M.M., and Gschwend, P.M., 1987, The role of colloids in the partitioning of solutes in natural waters, in Stumm, W., ed., Aquatic surface chemistry: New York, Wiley-Interscience, p. 405-422.

Nordstrom, D.K., and Alpers, C.N., 1999, Geochemistry of acid mine waters, in Plumlee, G.S. and Logsdon, M.J., eds., The environmental geochemistry of mineral deposits Part A: Processes, techniques, and health issues: Littleton, Colo., Society of Economic Geologists, p. 133-160.

Rantz, S.E., 1982, Measurement and computation of streamflow: Volume 1. Measurement of stage and discharge: U.S. Geological Survey Water-Supply Paper, 200 p.

Rocky Mountain Association of Geologists, 1972, Geologic atlas of the Rocky Mountain region, United States of America: Denver, Colo., Rocky Mountain Association of Geologists, $331 \mathrm{p}$.
Runkel, R.L., and Kimball, B.A., 2002, Evaluating remedial alternatives for an acid mine drainage stream: Application of a reactive transport model: Environmental Science \& Technology, v. 36, no. 5, p. 1093-1101.

Runkel, R.L., Kimball, B.A., McKnight, D.M., and Bencala, K.E., 1999, Reactive solute transport in streams: A surface complexation approach for trace metal sorption: Water Resources Research, v. 35, no. 12, p. 3829-3840.

Schemel, L.E., Kimball, B.A., and Bencala, K.E., 2000, Colloid formation and metal transport though two mixing zones affected by acid mine drainage near Silverton, Colorado: Applied Geochemistry, v. 15, no. 1003, p. 1018.

Singer, P.C., and Stumm, W., 1970, Acidic mine drainage: The rate-determining step: Science, v. 167, p. 1121-1123.

Smith, K.S., 1999, Metal sorption on mineral surfaces: An overview with examples relating to mineral deposits, in Plumlee, G.S. and Logsdon, M.J., eds., The environmental geochemistry of mineral deposits, Part A: Processes, techniques, and health issues: Littleton, Colo., Society of Economic Geologists, p. 161-182.

South Dakota Department of Environment and Natural Resources, 2004, Toxic pollutant criteria, accessed November 25, 2005, at http://legis.state.sd.us/rules/DisplayRule. aspx?Rule $=74: 51: 01: 0 B$

Strobel, M.L., Jarrell, G.J., Sawyer, J.F., Schleicher, J.R., and Fahrenbach, M.D., 1999, Distribution of hydrogeologic units in the Black Hills area, South Dakota: U.S. Geological survey Hydrologic Investigations Atlas HA-743, 3 sheets, scale 1:100,000.

Sullivan, A.B., and Drever, J.I., 2001, Geochemistry of suspended particles in a mine-affected mountain stream: Applied Geochemistry, v. 16, no. 15, p. 1663-1676.

Tate, C.M., Broshears, R.E., and McKnight, D.M., 1995, Phosphate dynamics in an acidic mountain stream: Interactions involving algal uptake, sorption by iron oxide, and photoreduction: Limnology and Oceanography, v. 40, no. 5, p. 938-946.

Taylor, J.R., 1997, An introduction to error analysis: The study of uncertainties in physical measurements, 2nd edition: Sausalito, California, University Science Books, 327 p.

U.S. Environmental Protection Agency, 2005, Gilt Edge mine clean up fact sheet, accessed September 13, 2005, at http:// www.epa.gov/region8/superfund/giltedge/gltfactsht.html

Ward, J.R. and Harr, C.A., 1990, Methods for collection and processing of surface-water and bed-material samples for physical and chemical analyses: U.S. Geological Survey Open-File Report 90-140, 71 p. 
Zellweger, G.W., 1994, Testing and comparison of four ionic tracers to measure stream flow loss by multiple tracer injection: Hydrological Processes, v. 8, p. 155-165.

Zellweger, G.W., Avanzino, R.J., and Bencala, K.E., 1989, Comparison of tracer-dilution and current-meter discharge measurements in a small gravel-bed stream, Little Lost Man Creek, California: U.S. Geological Survey Water-Resources Investigations Report 89-4150, 20 p. 
Table 4. Concentration of major ions in synoptic samples collected from Strawberry Creek, South Dakota, June 27, 2003

[All concentrations in milligrams per liter; Sample source: LBI, left-bank inflow; S, stream; RBI, right-bank inflow; Treatment: FA, filtered acidified; RA, unfiltered acidified; UFA, ultrafiltered acidified; alkalinity, as calcium carbonate]

\begin{tabular}{|c|c|c|c|c|c|c|c|c|c|c|c|}
\hline $\begin{array}{l}\text { Distance } \\
\text { along } \\
\text { study } \\
\text { reach } \\
\text { (meters) }\end{array}$ & $\begin{array}{l}\text { Sample } \\
\text { source }\end{array}$ & $\begin{array}{c}\text { Sample } \\
\text { time }\end{array}$ & $\begin{array}{l}\text { Treat- } \\
\text { ment }\end{array}$ & Calcium & $\begin{array}{l}\text { Magne- } \\
\text { sium }\end{array}$ & Sodium & $\begin{array}{l}\text { Potas- } \\
\text { sium }\end{array}$ & Alkalinity & Sulfate & Chloride & Silica \\
\hline \multirow[t]{2}{*}{12} & LBI & $14: 17$ & FA & 127 & 39.4 & 20.4 & 2.62 & 7.23 & 484 & 4.06 & 25.7 \\
\hline & & & RA & 127 & 38.9 & 20.5 & 2.83 & & 491 & & 28.2 \\
\hline 48 & & & RA & 124 & 36.7 & 20.4 & 2.57 & & 448 & & 25.4 \\
\hline \multirow[t]{2}{*}{71} & LBI & $14: 45$ & FA & 74.2 & 10.6 & 7.18 & 1.49 & 122 & 65.4 & 48.7 & 13.4 \\
\hline & & & $\mathrm{RA}$ & 74.2 & 10.7 & 7.19 & 1.52 & & 67.7 & & 13.4 \\
\hline 132 & $\mathrm{~S}$ & $13: 49$ & FA & 115 & 32.5 & 22.2 & 2.38 & 31.0 & 397 & 15.7 & 22.4 \\
\hline \multirow[t]{2}{*}{145} & RBI & $13: 50$ & FA & 33.3 & 3.99 & 3.03 & 0.56 & 98.3 & 6.72 & 7.33 & 14.3 \\
\hline & & & $\mathrm{RA}$ & 34.0 & 4.12 & 3.14 & 0.55 & & 7.69 & & 14.6 \\
\hline \multirow[t]{3}{*}{163} & $\mathrm{~S}$ & $13: 42$ & UFA & 74.4 & 17.9 & 12.1 & 1.40 & & 195 & 11.3 & 18.0 \\
\hline & & & FA & 75.4 & 17.7 & 12.5 & 1.34 & 66.1 & 191 & & 18.4 \\
\hline & & & RA & 73.7 & 17.7 & 12.4 & 1.35 & & 202 & & 18.8 \\
\hline \multirow[t]{2}{*}{218} & $\mathrm{~S}$ & $13: 37$ & FA & 73.0 & 17.9 & 12.7 & 1.43 & 72.2 & 195 & 11.4 & 18.3 \\
\hline & & & RA & 70.9 & 17.2 & 12.3 & 1.38 & & 194 & & 18.7 \\
\hline 229 & LBI & $14: 45$ & FA & 150 & 26.5 & 194 & 3.21 & 31.5 & 838 & 13.8 & 17.7 \\
\hline \multirow[t]{2}{*}{358} & $\mathrm{~S}$ & $13: 20$ & FA & 71.5 & 17.3 & 15.7 & 1.59 & 67.1 & 195 & 11.2 & 17.6 \\
\hline & & & $\mathrm{RA}$ & 71.9 & 17.5 & 15.4 & 1.54 & & 198 & & 17.7 \\
\hline 383 & LBI & $13: 10$ & FA & 403 & 76.0 & 59.6 & 7.63 & 47.5 & 1316 & 17.8 & 24.5 \\
\hline \multirow[t]{2}{*}{425} & $\mathrm{~S}$ & $13: 05$ & FA & 77.4 & 18.4 & 18.7 & 1.61 & 65.3 & 215 & 11.3 & 17.4 \\
\hline & & & RA & 75.4 & 17.8 & 18.5 & 1.57 & & 214 & & 17.7 \\
\hline 440 & LBI & $13: 00$ & FA & 76.1 & 16.9 & 38.0 & 1.43 & 66.3 & 239 & 12.5 & 11.7 \\
\hline \multirow[t]{2}{*}{459} & RBI & $12: 55$ & FA & 48.6 & 10.7 & 132 & 2.55 & 41.7 & 400 & 6.85 & 13.5 \\
\hline & & & RA & 48.1 & 10.8 & 132 & 2.83 & & 395 & & 16.6 \\
\hline \multirow[t]{2}{*}{486} & $\mathrm{~S}$ & $12: 50$ & FA & 78.4 & 18.3 & 22.8 & 1.75 & 65.8 & 221 & 11.2 & 17.2 \\
\hline & & & $\mathrm{RA}$ & 77.7 & 17.0 & 22.0 & 1.72 & & 222 & & 16.8 \\
\hline 498 & LBI & $12: 45$ & FA & 176 & 32.7 & 30.4 & 4.83 & 58.2 & 534 & 11.0 & 20.5 \\
\hline \multirow[t]{2}{*}{524} & $\mathrm{~S}$ & $12: 40$ & $\mathrm{FA}$ & 72.6 & 17.0 & 22.0 & 1.75 & 64.5 & 224 & 11.2 & 17.8 \\
\hline & & & $\mathrm{RA}$ & 78.8 & 17.1 & 23.3 & 1.62 & & 222 & & 16.9 \\
\hline
\end{tabular}


Table 4. Concentration of major ions in synoptic samples collected from Strawberry Creek, South Dakota, June 27, 2003 —Continued

\begin{tabular}{|c|c|c|c|c|c|c|c|c|c|c|c|}
\hline $\begin{array}{l}\text { Distance } \\
\text { along } \\
\text { study } \\
\text { reach } \\
\text { (meters) } \\
\end{array}$ & $\begin{array}{l}\text { Sample } \\
\text { source }\end{array}$ & $\begin{array}{c}\text { Sample } \\
\text { time }\end{array}$ & $\begin{array}{c}\text { Treat- } \\
\text { ment }\end{array}$ & Calcium & $\begin{array}{l}\text { Magne- } \\
\text { sium }\end{array}$ & Sodium & $\begin{array}{l}\text { Potas- } \\
\text { sium }\end{array}$ & Alkalinity & Sulfate & Chloride & Silica \\
\hline 551 & LBI & $12: 30$ & FA & 87.0 & 19.1 & 38.5 & 1.71 & 82.7 & 260 & 11.7 & 12.6 \\
\hline \multirow[t]{2}{*}{587} & $\mathrm{~S}$ & $12: 25$ & FA & 78.5 & 18.0 & 24.3 & 1.76 & 65.1 & 222 & 11.3 & 16.6 \\
\hline & & & RA & 78.4 & 17.7 & 24.0 & 1.76 & & 234 & & 17.1 \\
\hline 597 & RBI & $12: 20$ & FA & 114 & 17.9 & 45.8 & 3.31 & 107 & 321 & 5.64 & 12.8 \\
\hline 624 & RBI & $12: 10$ & FA & 102 & 19.0 & 153 & 3.62 & 127 & 512 & 7.00 & 13.4 \\
\hline 632 & RBI & $12: 03$ & FA & 172 & 31.1 & 15.1 & 4.84 & 131 & 434 & 3.17 & 27.1 \\
\hline \multirow[t]{2}{*}{647} & $\mathrm{~S}$ & $12: 13$ & FA & 86.8 & 18.8 & 27.1 & 2.03 & 70.5 & 247 & 10.4 & 17.2 \\
\hline & & & RA & 87.7 & 18.8 & 26.4 & 1.81 & & 251 & & 17.4 \\
\hline \multirow[t]{2}{*}{664} & RBI & $11: 51$ & FA & 132 & 29.8 & 43.9 & 4.11 & 140 & 389 & 3.27 & 17.7 \\
\hline & & & RA & 129 & 28.5 & 41.2 & 4.59 & & 392 & & 18.3 \\
\hline 672 & RBI & $11: 47$ & FA & 113 & 24.9 & 55.0 & 3.77 & 145 & 345 & 3.10 & 16.4 \\
\hline 691 & LBI & $11: 40$ & FA & 97.0 & 20.6 & 87.6 & 3.00 & 87.3 & 397 & 9.82 & 13.9 \\
\hline \multirow[t]{2}{*}{715} & $\mathrm{~S}$ & $11: 27$ & FA & 87.5 & 19.3 & 30.5 & 2.22 & 77.5 & 264 & 9.95 & 17.0 \\
\hline & & & RA & 88.4 & 19.6 & 31.0 & 2.24 & & 271 & & 17.3 \\
\hline 719 & RBI & $11: 30$ & FA & 89.5 & 21.5 & 24.5 & 3.00 & 114 & 247 & 2.46 & 12.3 \\
\hline \multirow[t]{2}{*}{776} & $\mathrm{~S}$ & $11: 22$ & FA & 87.4 & 19.2 & 30.0 & 2.18 & 77.1 & 260 & 9.84 & 16.9 \\
\hline & & & RA & 90.9 & 20.3 & 30.9 & 2.22 & & 280 & & 17.4 \\
\hline 831 & LBI & $11: 10$ & FA & 337 & 92.9 & 30.3 & 9.98 & 1.00 & 1324 & 2.35 & 35.0 \\
\hline \multirow[t]{2}{*}{858} & $\mathrm{~S}$ & 11:03 & FA & 88.1 & 19.7 & 29.6 & 2.37 & 76.3 & 270 & 9.78 & 16.2 \\
\hline & & & RA & 84.1 & 19.3 & 28.3 & 2.17 & & 262 & & 16.6 \\
\hline 870 & LBI & $10: 55$ & FA & 376 & 117 & 31.8 & 10.2 & 20.2 & 1402 & 2.33 & 30.2 \\
\hline \multirow[t]{2}{*}{896} & $S$ & $10: 45$ & FA & 90.7 & 20.6 & 30.3 & 2.23 & 75.5 & 277 & 9.74 & 16.2 \\
\hline & & & RA & 91.4 & 20.7 & 29.5 & 2.15 & & 274 & & 16.8 \\
\hline 961 & LBI & $10: 38$ & FA & 66.2 & 22.7 & 8.87 & 4.37 & 11.9 & 260 & 1.14 & 27.6 \\
\hline \multirow[t]{2}{*}{1,036} & $\mathrm{~S}$ & $10: 32$ & FA & 92.2 & 21.3 & 29.9 & 2.43 & 75.8 & 287 & 9.59 & 17.0 \\
\hline & & & RA & 92.9 & 20.9 & 30.0 & 2.29 & & 287 & & 16.8 \\
\hline \multirow[t]{2}{*}{1,064} & LBI & $10: 25$ & FA & 104 & 19.4 & 146 & 5.97 & 55.7 & 594 & 4.47 & 11.6 \\
\hline & & & RA & 109 & 20.1 & 151 & 5.40 & & 594 & & 11.7 \\
\hline \multirow[t]{2}{*}{1,120} & S & $10: 19$ & FA & 92.2 & 21.2 & 37.9 & 2.70 & 72.6 & 312 & 9.17 & 16.9 \\
\hline & & & RA & 86.5 & 19.9 & 36.0 & 2.69 & & 294 & & 16.4 \\
\hline \multirow[t]{2}{*}{1,200} & $S$ & $10: 07$ & FA & 92.6 & 21.5 & 40.7 & 2.62 & 71.7 & 319 & 9.09 & 17.1 \\
\hline & & & RA & 87.3 & 20.2 & 37.5 & 2.77 & & 298 & & 16.7 \\
\hline 1,207 & RBI & $10: 05$ & FA & 47.8 & 13.1 & 11.3 & 3.24 & 98.9 & 102 & 0.97 & 17.0 \\
\hline \multirow[t]{2}{*}{1,320} & $\mathrm{~S}$ & $9: 54$ & FA & 90.2 & 20.9 & 40.3 & 2.67 & 72.7 & 305 & 9.43 & 16.4 \\
\hline & & & RA & 93.3 & 20.9 & 40.1 & 2.60 & & 312 & & 16.7 \\
\hline \multirow[t]{2}{*}{1,458} & $S$ & $9: 47$ & FA & 88.2 & 19.9 & 39.0 & 2.55 & 69.8 & 298 & 8.86 & 15.8 \\
\hline & & & RA & 90.5 & 20.1 & 37.7 & 2.46 & & 287 & & 15.5 \\
\hline
\end{tabular}


Table 4. Concentration of major ions in synoptic samples collected from Strawberry Creek, South Dakota, June 27, 2003 -Continued

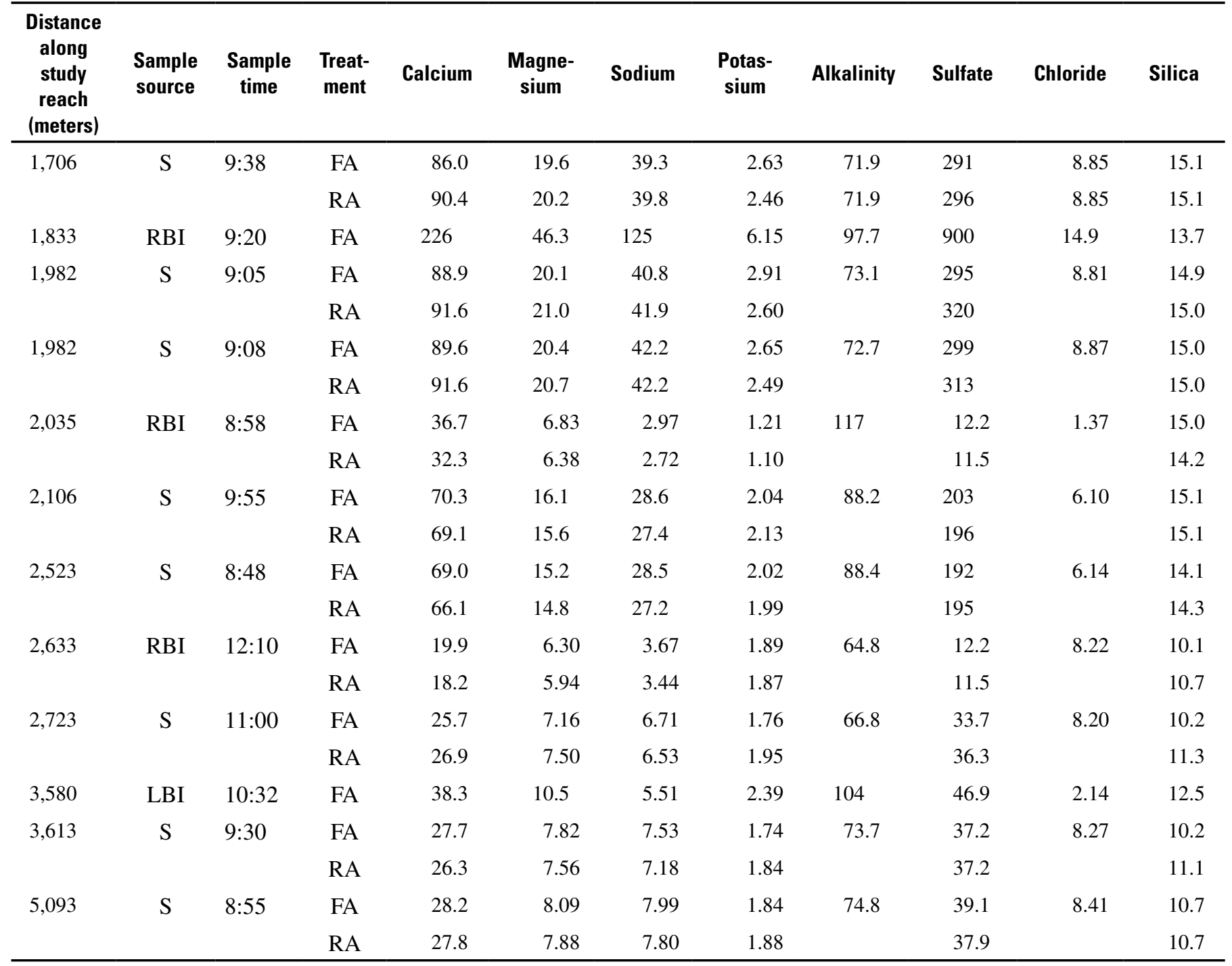


[All concentrations in micrograms per liter; Sample source: LBI, left-bank inflow; S, stream; RBI, right-bank inflow; Treatment: FA, filtered acidified; RA, unfiltered acidified; UFA, ultrafiltered acidified]

\begin{tabular}{|c|c|c|c|c|c|c|c|c|c|c|c|c|c|c|c|c|c|c|}
\hline $\begin{array}{c}\text { Dis- } \\
\text { tance } \\
\text { along } \\
\text { study } \\
\text { reach } \\
\text { (me- } \\
\text { ters) } \\
\end{array}$ & $\begin{array}{l}\text { Sample } \\
\text { source }\end{array}$ & $\begin{array}{l}\text { Sam- } \\
\text { ple } \\
\text { time }\end{array}$ & $\begin{array}{c}\text { Treat- } \\
\text { ment }\end{array}$ & $\begin{array}{c}\text { Alumi- } \\
\text { num }\end{array}$ & $\begin{array}{c}\text { Arse- } \\
\text { nic }\end{array}$ & $\begin{array}{c}\text { Bari- } \\
\text { um }\end{array}$ & $\begin{array}{l}\text { Cad- } \\
\text { mium }\end{array}$ & $\begin{array}{l}\text { Chro- } \\
\text { mium }\end{array}$ & Cobalt & Copper & Iron & Lead & $\begin{array}{l}\text { Manga- } \\
\text { nese }\end{array}$ & $\begin{array}{c}\text { Mo- } \\
\text { lybde- } \\
\text { num }\end{array}$ & $\begin{array}{c}\text { Nick- } \\
\text { el }\end{array}$ & $\begin{array}{c}\text { Stron- } \\
\text { tium }\end{array}$ & $\begin{array}{l}\text { Vana- } \\
\text { dium }\end{array}$ & Zinc \\
\hline \multirow[t]{2}{*}{12} & LBI & 14:17 & FA & 185 & $<0.4$ & 21.0 & 62.0 & 0.074 & 14.2 & 174 & $<24$ & $<0.3$ & 2,310 & 1.09 & 89.8 & 659 & .127 & 1,960 \\
\hline & & & RA & 2,230 & $<.4$ & 20.5 & 60.9 & .197 & 14.5 & 252 & 50.6 & .33 & 2,180 & .67 & 91.1 & 661 & .213 & 1,940 \\
\hline \multirow[t]{2}{*}{71} & LBI & $14: 45$ & FA & 15.8 & .74 & 59.6 & .48 & .081 & .57 & 20.6 & $<24$ & $<.3$ & 14.2 & 1.20 & 1.78 & 256 & .183 & 28.7 \\
\hline & & & RA & 47.6 & .82 & 58.1 & .60 & .101 & .56 & 24.6 & $<24$ & $<.3$ & 15.0 & 1.18 & 1.74 & 287 & .196 & 21.5 \\
\hline \multirow[t]{2}{*}{132} & S & $13: 49$ & FA & 98.7 & $<.4$ & 28.8 & 38.3 & .119 & 11.5 & 114 & $<24$ & $<.3$ & 1,400 & .95 & 57.9 & 594 & .161 & 1,140 \\
\hline & & & RA & 1,500 & .50 & 30.6 & 40.5 & .233 & 12.4 & 242 & 70.6 & .58 & 1,380 & .94 & 60.0 & 570 & .258 & 1,160 \\
\hline 132 & $S$ & $13: 50$ & FA & 96.3 & $<.4$ & 30.2 & 38.5 & .092 & 11.1 & 114 & $<24$ & $<.3$ & 1,430 & .87 & 58.3 & 557 & .142 & 1,250 \\
\hline \multirow{2}{*}{163} & & & $\mathrm{FA}$ & 120 & .40 & 20.3 & 17.0 & .065 & 5.23 & 49.9 & $<24$ & $<.3$ & 667 & .77 & 25.2 & 352 & .211 & 584 \\
\hline & & & RA & 709 & .66 & 23.3 & 17.8 & .164 & 5.17 & 91.8 & 60.7 & .46 & 688 & .78 & 25.4 & 378 & .303 & 557 \\
\hline \multirow[t]{2}{*}{218} & S & $13: 37$ & FA & 115 & .47 & 19.7 & 16.4 & .112 & 5.20 & 42.4 & $<24$ & $<.3$ & 628 & .73 & 24.9 & 319 & .203 & 449 \\
\hline & & & RA & 621 & .61 & 22.2 & 18.0 & .167 & 5.77 & 83.8 & 50.0 & .34 & 619 & .74 & 27.1 & 361 & .276 & 495 \\
\hline 229 & LBI & $14: 45$ & FA & 1,070 & $<.4$ & 23.4 & 1.63 & .136 & 4.68 & 8.0 & $<24$ & $<.3$ & 990 & $<.25$ & 18.6 & 682 & $<.16$ & 198 \\
\hline 235 & RBI & $14: 40$ & FA & 35.6 & .68 & 6.81 & .18 & .081 & .41 & 1.9 & $<24$ & $<.3$ & 12.8 & .43 & .26 & 291 & .474 & 37.7 \\
\hline \multirow[t]{2}{*}{284} & $\mathrm{~S}$ & $13: 32$ & FA & 103 & .46 & 21.2 & 15.3 & .080 & 4.76 & 37.5 & $<24$ & $<.3$ & 564 & .68 & 22.9 & 321 & .204 & 425 \\
\hline & & & RA & 507 & .57 & 20.0 & 15.2 & .158 & 4.62 & 69.2 & 39.5 & $<.3$ & 567 & .71 & 22.4 & 345 & .268 & 431 \\
\hline 316 & LBI & $14: 55$ & FA & 84.9 & $<.4$ & 11.9 & 1.40 & .093 & 1.35 & 7.5 & $<24$ & $<.3$ & 7.01 & .25 & 2.94 & 304 & .115 & 271 \\
\hline 330 & RBI & $13: 30$ & FA & 30.7 & $<.4$ & 4.51 & $<.13$ & .094 & .08 & 1.6 & $<24$ & $<.3$ & $<5$ & $<.25$ & .18 & 84.9 & .289 & 144 \\
\hline
\end{tabular}




\begin{tabular}{|c|c|c|c|c|c|c|c|c|c|c|c|c|c|c|c|c|c|c|}
\hline $\begin{array}{c}\text { Dis- } \\
\text { tance } \\
\text { along } \\
\text { study } \\
\text { reach } \\
\text { (me- } \\
\text { ters) }\end{array}$ & $\begin{array}{l}\text { Sample } \\
\text { source }\end{array}$ & $\begin{array}{c}\text { Sam- } \\
\text { ple } \\
\text { time }\end{array}$ & $\begin{array}{l}\text { Treat- } \\
\text { ment }\end{array}$ & $\begin{array}{c}\text { Alumi- } \\
\text { num }\end{array}$ & $\begin{array}{l}\text { Arse- } \\
\text { nic }\end{array}$ & $\begin{array}{c}\text { Bari- } \\
\text { um }\end{array}$ & $\begin{array}{l}\text { Cad- } \\
\text { mium }\end{array}$ & $\begin{array}{l}\text { Chro- } \\
\text { mium }\end{array}$ & Cobalt & Copper & Iron & Lead & $\begin{array}{c}\text { Manga- } \\
\text { nese }\end{array}$ & $\begin{array}{l}\text { Mo- } \\
\text { lybde- } \\
\text { num }\end{array}$ & $\begin{array}{l}\text { Nick- } \\
\text { el }\end{array}$ & $\begin{array}{c}\text { Stron- } \\
\text { tium }\end{array}$ & $\begin{array}{l}\text { Vana- } \\
\text { dium }\end{array}$ & Zinc \\
\hline \multirow[t]{2}{*}{425} & S & $13: 05$ & FA & 95.7 & .50 & 19.0 & 12.5 & .091 & 3.90 & 29.0 & $<24$ & $<.3$ & 479 & .78 & 19.1 & 385 & .207 & 305 \\
\hline & & & RA & 394 & .57 & 20.1 & 12.4 & .127 & 3.83 & 47.4 & 41.8 & $<.3$ & 477 & .76 & 19.0 & 342 & .254 & 319 \\
\hline 440 & LBI & $13: 00$ & FA & 53.5 & $<.4$ & 12.7 & .83 & .131 & .48 & 2.8 & $<24$ & $<.3$ & $<5$ & 1.05 & .66 & 280 & .066 & 42.3 \\
\hline \multirow[t]{2}{*}{459} & RBI & $12: 55$ & FA & 205 & $<.4$ & 12.5 & .65 & .077 & 1.02 & 8.1 & $<24$ & $<.3$ & $<5$ & $<.25$ & 7.93 & 207 & $<.06$ & 71.5 \\
\hline & & & RA & 1,410 & 3.4 & 18.9 & .74 & .854 & 2.04 & 43.6 & 1,170 & 4.61 & 50.9 & $<.25$ & 9.66 & 195 & 1.55 & 74.1 \\
\hline \multirow[t]{2}{*}{486} & $S$ & $12: 50$ & FA & 93.5 & .43 & 19.0 & 11.4 & .103 & 3.71 & 26.4 & $<24$ & $<.3$ & 434 & .72 & 18.1 & 351 & .197 & 275 \\
\hline & & & RA & 335 & .65 & 20.1 & 11.6 & .134 & 3.61 & 42.5 & 58.0 & .30 & 434 & .71 & 17.6 & 335 & .264 & 277 \\
\hline 498 & LBI & $12: 45$ & FA & 13.8 & .48 & 31.2 & 1.22 & .157 & 2.43 & 3.9 & 32.9 & $<.3$ & 313 & .34 & 4.38 & 615 & .162 & 216 \\
\hline \multirow[t]{2}{*}{524} & $S$ & $12: 40$ & FA & 90.5 & $<.4$ & 19.0 & 10.9 & .058 & 3.49 & 24.5 & $<24$ & $<.3$ & 388 & .79 & 17.3 & 384 & .196 & 229 \\
\hline & & & RA & 318 & .55 & 19.1 & 11.1 & .109 & 3.58 & 40.5 & 42.5 & $<.3$ & 413 & .73 & 17.2 & 351 & .260 & 331 \\
\hline 551 & LBI & $12: 30$ & FA & 10.4 & .41 & 14.1 & .517 & .133 & .580 & 1.8 & $<24$ & $<.3$ & 16.8 & .82 & .385 & 337 & .070 & 51.9 \\
\hline \multirow[t]{2}{*}{587} & $S$ & $12: 25$ & FA & 90.4 & .49 & 18.4 & 9.93 & .096 & 3.18 & 23.8 & $<24$ & $<.3$ & 370 & .80 & 16.0 & 373 & .197 & 221 \\
\hline & & & RA & 289 & .57 & 17.8 & 9.61 & .127 & 2.89 & 35.7 & 35.3 & $<.3$ & 381 & .81 & 14.8 & 351 & .232 & 231 \\
\hline 597 & RBI & $12: 20$ & FA & 25.6 & $<.4$ & 15.4 & .92 & .094 & .76 & 3.9 & $<24$ & $<.3$ & $<5$ & .58 & .92 & 321 & .076 & 131 \\
\hline 624 & RBI & $12: 10$ & FA & 29.3 & .92 & 18.2 & .87 & .063 & 2.14 & 1.8 & 36.2 & $<.3$ & 525 & 1.64 & 1.77 & 330 & .111 & 200 \\
\hline 632 & RBI & $12: 03$ & FA & $<5$ & 2.7 & 36.1 & $<.13$ & .095 & .93 & $<.49$ & 2,380 & $<.3$ & 926 & 1.03 & 1.41 & 716 & .091 & 84.4 \\
\hline \multirow[t]{2}{*}{647} & $S$ & $12: 13$ & FA & 211 & .44 & 17.9 & 8.43 & .100 & 2.70 & 20.5 & $<24$ & $<.3$ & 311 & .76 & 13.6 & 409 & .196 & 196 \\
\hline & & & RA & 345 & .75 & 20.2 & 8.56 & .191 & 2.54 & 33.9 & 139 & .65 & 343 & .78 & 12.7 & 427 & .384 & 205 \\
\hline \multirow[t]{2}{*}{664} & RBI & $11: 51$ & FA & 5.4 & $<.4$ & 25.4 & $<.13$ & .099 & .14 & .95 & $<24$ & $<.3$ & $<5$ & .53 & 1.64 & 401 & .164 & 4.91 \\
\hline & & & RA & 73.0 & $<.4$ & 24.4 & $<.13$ & .137 & .22 & 2.4 & 82.1 & .38 & 6.24 & .51 & 1.57 & 370 & .266 & 5.89 \\
\hline 672 & RBI & $11: 47$ & FA & 7.1 & $<.4$ & 21.8 & $<.13$ & .062 & .12 & .76 & $<24$ & $<.3$ & $<5$ & .62 & .37 & 305 & .184 & 21.0 \\
\hline 691 & LBI & $11: 40$ & FA & 15.3 & $<.4$ & 8.85 & .93 & .095 & .41 & 3.4 & $<24$ & $<.3$ & $<5$ & .62 & 1.18 & 319 & .086 & 81.3 \\
\hline \multirow[t]{2}{*}{715} & $\mathrm{~S}$ & $11: 27$ & FA & 66.4 & .44 & 17.6 & 7.58 & .115 & 2.34 & 18.3 & $<24$ & $<.3$ & 273 & .77 & 12.3 & 417 & .192 & 172 \\
\hline & & & RA & 223 & .62 & 16.9 & 7.60 & .123 & 2.13 & 27.4 & 35.2 & $<.3$ & 288 & .84 & 11.3 & 376 & .215 & 180 \\
\hline 719 & RBI & $11: 30$ & FA & $<5$ & $<.4$ & 39.0 & $<.13$ & .041 & .08 & 2.2 & $<24$ & $<.3$ & $<5$ & .52 & .45 & 280 & .064 & 8.87 \\
\hline 776 & $S$ & & FA & 67.3 & .43 & 17.4 & 7.51 & .062 & 2.08 & 16.7 & $<24$ & $<.3$ & 265 & .73 & 12.1 & 377 & .160 & 161 \\
\hline 776 & $\mathrm{~S}$ & $11: 22$ & RA & 236 & .59 & 18.4 & 7.17 & .113 & 2.03 & 25.4 & 48.2 & $<.3$ & 280 & .70 & 11.4 & 370 & .227 & 189 \\
\hline
\end{tabular}


Table 5. Concentration of trace elements in synoptic samples collected from Strawberry and Bear Butte Creeks, South Dakota, June 27, 2003 - Continued

\begin{tabular}{|c|c|c|c|c|c|c|c|c|c|c|c|c|c|c|c|c|c|c|}
\hline $\begin{array}{c}\text { Dis- } \\
\text { tance } \\
\text { along } \\
\text { study } \\
\text { reach } \\
\text { (me- } \\
\text { ters) }\end{array}$ & $\begin{array}{l}\text { Sample } \\
\text { source }\end{array}$ & $\begin{array}{c}\text { Sam- } \\
\text { ple } \\
\text { time }\end{array}$ & $\begin{array}{l}\text { Treat- } \\
\text { ment }\end{array}$ & $\begin{array}{c}\text { Alumi- } \\
\text { num }\end{array}$ & $\begin{array}{l}\text { Arse- } \\
\text { nic }\end{array}$ & $\begin{array}{c}\text { Bari- } \\
\text { um }\end{array}$ & $\begin{array}{l}\text { Cad- } \\
\text { mium }\end{array}$ & $\begin{array}{l}\text { Chro- } \\
\text { mium }\end{array}$ & Cobalt & Copper & Iron & Lead & $\begin{array}{c}\text { Manga- } \\
\text { nese }\end{array}$ & $\begin{array}{l}\text { Mo- } \\
\text { lybde- } \\
\text { num }\end{array}$ & $\begin{array}{l}\text { Nick- } \\
\text { el }\end{array}$ & $\begin{array}{l}\text { Stron- } \\
\text { tium }\end{array}$ & $\begin{array}{l}\text { Vana- } \\
\text { dium }\end{array}$ & Zinc \\
\hline 831 & LBI & $11: 10$ & FA & 313 & 1.2 & 21.2 & 6.76 & .055 & 154 & 4.7 & 59,100 & $<.3$ & 6,900 & $<.25$ & 387 & 1094 & $<0.06$ & 2,710 \\
\hline \multirow[t]{2}{*}{858} & $\mathrm{~S}$ & $11: 03$ & FA & 57.6 & $<.4$ & 19.0 & 7.39 & .084 & 2.63 & 11.4 & $<24$ & $<.3$ & 299 & .70 & 14.0 & 393 & .145 & 172 \\
\hline & & & RA & 200 & .51 & 19.7 & 7.91 & .132 & 2.72 & 25.4 & 155 & $<.3$ & 300 & 1.26 & 14.8 & 403 & .245 & 185 \\
\hline 870 & LBI & $10: 55$ & FA & 74.8 & .51 & 33.3 & 20.2 & .037 & 143 & 29.4 & 10,500 & $<.3$ & 6,080 & .47 & 323 & 953 & $<0.06$ & 2,370 \\
\hline \multirow[t]{2}{*}{896} & $S$ & $10: 45$ & FA & 60.9 & $<.4$ & 17.8 & 6.98 & .076 & 3.27 & 7.5 & 28.6 & $<.3$ & 332 & .74 & 14.9 & 376 & .095 & 158 \\
\hline & & & RA & 198 & .58 & 18.3 & 7.54 & .104 & 3.05 & 24.4 & 417 & $<.3$ & 351 & .70 & 13.6 & 393 & .201 & 207 \\
\hline 961 & LBI & $10: 38$ & FA & 165 & 2.2 & 94.3 & 3.46 & .103 & 1.15 & 33.7 & 24.7 & $<.3$ & 129 & $<.25$ & 76.4 & 320 & .208 & 503 \\
\hline \multirow[t]{2}{*}{1,036} & $S$ & $10: 32$ & FA & 48.4 & $<.4$ & 18.4 & 6.94 & .073 & 3.19 & 7.5 & $<24$ & $<.3$ & 331 & .69 & 15.7 & 383 & .090 & 180 \\
\hline & & & RA & 197 & .58 & 18.3 & 7.77 & .116 & 3.27 & 24.1 & 377 & $<.3$ & 346 & .69 & 15.1 & 403 & .208 & 209 \\
\hline \multirow[t]{2}{*}{1,064} & LBI & $10: 25$ & FA & 44.8 & .96 & 19.0 & 1.58 & .071 & 2.40 & 4.5 & $<24$ & $<.3$ & 330 & .34 & 7.83 & 415 & .140 & 14.9 \\
\hline & & & RA & 100 & 1.1 & 17.2 & 1.74 & .091 & 2.43 & 8.2 & 89.7 & $<.3$ & 352 & .36 & 7.65 & 426 & .178 & 23.5 \\
\hline \multirow[t]{2}{*}{1,120} & $S$ & $10: 19$ & FA & 43.6 & .41 & 17.7 & 6.56 & .073 & 2.97 & 7.3 & 36.6 & $<.3$ & 319 & .70 & 14.5 & 396 & .093 & 171 \\
\hline & & & RA & 820 & .54 & 21.0 & 7.48 & .133 & 3.21 & 21.9 & 314 & $<.3$ & 310 & .76 & 15.3 & 439 & .215 & 185 \\
\hline \multirow[t]{2}{*}{1,200} & $S$ & $10: 07$ & FA & 51.0 & $<.4$ & 17.2 & 6.36 & .076 & 2.85 & 7.4 & 28.6 & $<.3$ & 309 & .72 & 14.9 & 420 & .091 & 164 \\
\hline & & & RA & 151 & .54 & 18.7 & 6.97 & .136 & 2.78 & 19.6 & 276 & $<.3$ & 292 & .69 & 14.5 & 416 & .198 & 182 \\
\hline 1,207 & RBI & $10: 05$ & FA & 447 & 2.3 & 10.2 & $<.13$ & .052 & 11.3 & $<.49$ & 1,650 & $<.3$ & 377 & $<.25$ & 21.1 & 89.6 & $<0.06$ & 65.1 \\
\hline \multirow[t]{2}{*}{1,320} & $\mathrm{~S}$ & $9: 54$ & FA & 38.5 & $<.4$ & 18.9 & 6.21 & .070 & 2.64 & 6.8 & $<24$ & $<.3$ & 275 & .75 & 14.1 & 393 & .093 & 156 \\
\hline & & & RA & 137 & .48 & 18.2 & 6.31 & .118 & 2.41 & 16.9 & 242 & $<.3$ & 285 & .67 & 12.7 & 386 & .161 & 174 \\
\hline \multirow[t]{2}{*}{1,458} & $\mathrm{~S}$ & $9: 47$ & FA & 34.7 & .40 & 17.3 & 5.21 & .065 & 2.05 & 6.2 & $<24$ & $<.3$ & 226 & .72 & 11.1 & 370 & .082 & 133 \\
\hline & & & RA & 133 & .51 & 16.7 & 5.80 & .150 & 2.18 & 15.5 & 213 & .30 & 241 & .76 & 11.5 & 378 & .192 & 149 \\
\hline \multirow[t]{2}{*}{1,706} & $\mathrm{~S}$ & $9: 38$ & FA & 31.8 & $<.4$ & 16.7 & 4.79 & .053 & 1.77 & 5.7 & $<24$ & 1.20 & 184 & .71 & 10.8 & 351 & .077 & 110 \\
\hline & & & RA & 98.5 & .47 & 15.9 & 4.99 & .111 & 1.68 & 12.1 & 163 & $<.3$ & 192 & .72 & 9.92 & 386 & .152 & 129 \\
\hline 1,833 & RBI & $9: 20$ & FA & $<5$ & $<.4$ & 38.5 & .73 & .045 & 3.47 & 1.2 & 294 & $<.3$ & 650 & .98 & 10.9 & 608 & $<.06$ & 72.4 \\
\hline \multirow[t]{2}{*}{1,982} & $\mathrm{~S}$ & 9:05 & FA & 28.9 & $<.4$ & 15.3 & 4.14 & .065 & 1.42 & 5.3 & $<24$ & $<.3$ & 145 & .80 & 9.21 & 405 & .078 & 104 \\
\hline & & & RA & 95.5 & $<.4$ & 18.0 & 4.49 & .092 & 1.46 & 10.4 & 133 & $<.3$ & 153 & .75 & 9.53 & 399 & .149 & 113 \\
\hline \multirow[t]{2}{*}{1,982} & $S$ & 9:08 & FA & 27.0 & $<.4$ & 16.1 & 4.09 & .100 & 1.36 & 5.2 & 24.6 & $<.3$ & 150 & .77 & 8.81 & 375 & .075 & 106 \\
\hline & & & RA & 94.4 & $<.4$ & 16.3 & 4.43 & .142 & 1.45 & 10.3 & 131 & $<.3$ & 152 & .76 & 9.04 & 367 & .144 & 109 \\
\hline
\end{tabular}


Table 5. Concentration of trace elements in synoptic samples collected from Strawberry and Bear Butte Creeks, South Dakota, June 27, 2003 - Continued

\begin{tabular}{|c|c|c|c|c|c|c|c|c|c|c|c|c|c|c|c|c|c|c|}
\hline $\begin{array}{c}\text { Dis- } \\
\text { tance } \\
\text { along } \\
\text { study } \\
\text { reach } \\
\text { (me- } \\
\text { ters) }\end{array}$ & $\begin{array}{l}\text { Sample } \\
\text { source }\end{array}$ & $\begin{array}{c}\text { Sam- } \\
\text { ple } \\
\text { time }\end{array}$ & $\begin{array}{l}\text { Treat- } \\
\text { ment }\end{array}$ & $\begin{array}{c}\text { Alumi- } \\
\text { num }\end{array}$ & $\begin{array}{l}\text { Arse- } \\
\text { nic }\end{array}$ & $\begin{array}{l}\text { Bari- } \\
\text { um }\end{array}$ & $\begin{array}{l}\text { Cad- } \\
\text { mium }\end{array}$ & $\begin{array}{l}\text { Chro- } \\
\text { mium }\end{array}$ & Cobalt & Copper & Iron & Lead & $\begin{array}{c}\text { Manga- } \\
\text { nese }\end{array}$ & $\begin{array}{l}\text { Mo- } \\
\text { lybde- } \\
\text { num }\end{array}$ & $\begin{array}{l}\text { Nick- } \\
\text { el }\end{array}$ & $\begin{array}{c}\text { Stron- } \\
\text { tium }\end{array}$ & $\begin{array}{l}\text { Vana- } \\
\text { dium }\end{array}$ & Zinc \\
\hline \multirow[t]{2}{*}{2,035} & RBI & $8: 58$ & FA & 11.3 & $<.4$ & 20.2 & $<.13$ & .055 & .05 & $<.49$ & $<24$ & $<.3$ & $<5$ & .32 & .28 & 174 & .290 & 5.47 \\
\hline & & & RA & 74.2 & .42 & 20.4 & $<.13$ & .110 & .07 & $<.49$ & 89.0 & $<.3$ & 9.51 & .30 & .34 & 179 & .356 & 3.25 \\
\hline \multirow[t]{2}{*}{2,106} & $S$ & $9: 55$ & FA & 19.1 & $<.4$ & 16.6 & 2.47 & .051 & .79 & 3.3 & $<24$ & $<.3$ & 92.0 & .61 & 5.43 & 280 & .140 & 63.4 \\
\hline & & & RA & 87.1 & .41 & 18.5 & 2.66 & .116 & .90 & 6.8 & 112 & $<.3$ & 97.0 & .62 & 5.84 & 283 & .217 & 66.9 \\
\hline \multirow[t]{2}{*}{2,523} & $S$ & $8: 48$ & FA & 21.5 & $<.4$ & 16.4 & 1.97 & .061 & .61 & 3.4 & $<24$ & $<.3$ & 69.7 & .60 & 4.61 & 307 & .132 & 46.1 \\
\hline & & & RA & 76.2 & .44 & 19.3 & 2.26 & .144 & .71 & 6.7 & 96.7 & .51 & 64.9 & .61 & 5.09 & 318 & .241 & 51.4 \\
\hline \multirow[t]{2}{*}{2,633} & RBI & $12: 10$ & FA & 43.3 & 1.3 & 41.7 & $<.13$ & .096 & .15 & 1.0 & 170 & $<.3$ & $<5$ & $<.25$ & 1.15 & 93.0 & .253 & 6.73 \\
\hline & & & RA & 244 & 1.6 & 43.8 & $<.13$ & .311 & .28 & 1.4 & 572 & .42 & 30.7 & $<.25$ & 1.57 & 89.0 & .577 & $<3$ \\
\hline \multirow[t]{2}{*}{2,723} & $S$ & $11: 00$ & FA & 43.2 & 1.1 & 40.6 & .16 & .104 & .17 & 1.3 & 145 & $<.3$ & 9.06 & .274 & 1.60 & 120 & .220 & 3.31 \\
\hline & & & RA & 658 & 1.5 & 45.1 & .21 & .298 & .29 & 2.2 & 526 & .44 & 30.2 & .255 & 1.72 & 121 & .532 & 7.04 \\
\hline 3,580 & LBI & $10: 32$ & FA & $<5$ & 1.1 & 56.1 & $<.13$ & .044 & .11 & 1.9 & $<24$ & $<.3$ & 11.9 & .266 & .89 & 133 & .071 & $<3$ \\
\hline \multirow[t]{2}{*}{3,613} & $S$ & $9: 30$ & FA & 13.5 & .78 & 38.4 & .13 & .094 & .12 & 1.3 & 34.8 & $<.3$ & 15.9 & $<.25$ & 1.29 & 114 & .138 & $<3$ \\
\hline & & & RA & 181 & 1.1 & 44.9 & .25 & .208 & .24 & 2.2 & 401 & $<.3$ & 30.7 & .253 & 1.58 & 122 & .390 & 7.83 \\
\hline \multirow[t]{2}{*}{5,093} & $\mathrm{~S}$ & $8: 55$ & FA & 13.0 & .93 & 39.1 & $<.13$ & .091 & .114 & 1.4 & 25.5 & $<.3$ & 10.1 & .291 & 1.28 & 135 & .134 & 5.57 \\
\hline & & & RA & 136 & 1.2 & 46.2 & .234 & .238 & .244 & 2.4 & 359 & .314 & 24.4 & .280 & 1.60 & 132 & .378 & 8.70 \\
\hline
\end{tabular}





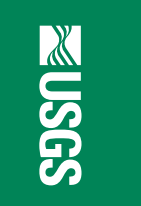

옹

号

交

등

c

苛

吕

₹

ก

疍

จุญ

宁

号

뭉

\}

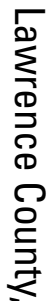

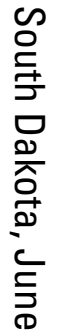

